
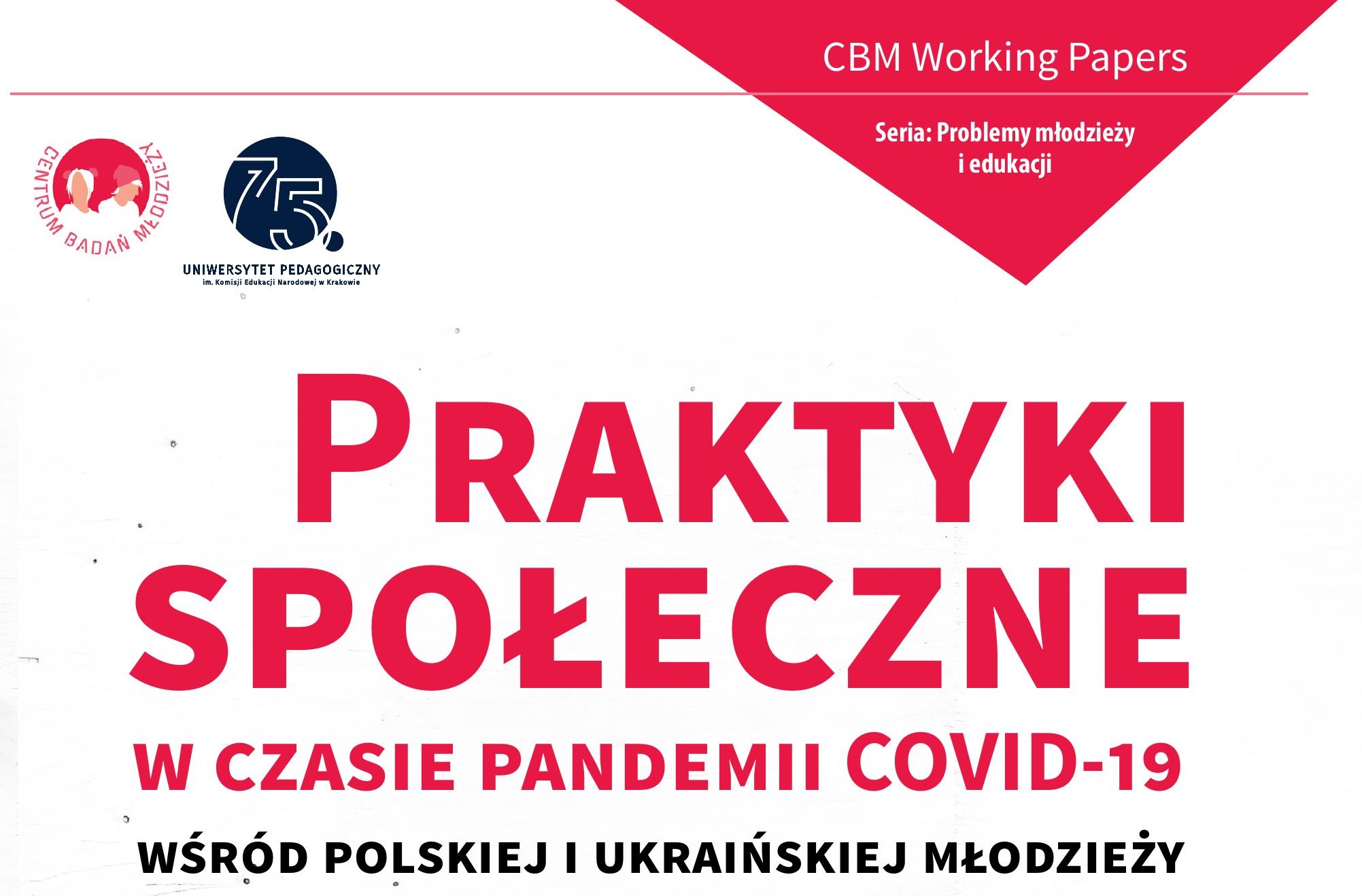

Piotr Długgosz, Liudmyla Kryvachuk, Olena Shyyan

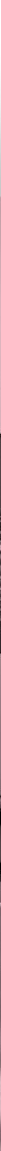


Recenzent: dr hab., prof. UP Krzysztof Czekaj

Przygotowanie wydawnicze:

Studio DTP Academicon | dtp.academicon.pl | dtp@academicon.pl

Redakcja i korekta tekstu w języku polskim: Piotr Janas

Redakcja i korekta tekstu w języku ukraińskim: Mariana Kril

Łamanie: Patrycja Waleszczak

Projekt okładki i stron tytułowych: Patrycja Waleszczak

(C) Copyright by Wydawnictwo Academicon, Lublin 2021

ISBN [ebook]: 978-83-62475-58-2

DOI: $10.52097 /$ acapress. 9788362475582

Wydawca: Wydawnictwo Academicon

ul. H. Modrzejewskiej 13, 20-810 Lublin

tel.: 603072530

e-mail:wydawnictwo@academicon.pl

www: wydawnictwo.academicon.pl 


\title{
PRAKTYKI SPOŁECZNE W CZASIE PANDEMII COVID-19 WŚRÓD POLSKIEJ I UKRAIŃSKIEJ MŁODZIEŻY
}

\begin{abstract}
Abstrakt: Raport prezentuje wyniki badań dotyczące polskich i ukraińskich uczniów przebywających w domach podczas lockdownu. Głównym celem badawczym była próba odpowiedzenia na pytanie o to, w jaki sposób sobie radzą uczniowie z zagrożeniem pandemią COVID-19, a także czy pojawiają się różnice między młodzieżą polską i ukraińską w zakresie stosunku do pandemii, dobrostanu psychologicznego, reakcji na zagrożenie, wykorzystywania internetu w kwarantannie, form spędzania czasu wolnego oraz oceny zdalnego nauczania i jego wpływu na szanse życiowe i edukacyjne.

Badania w obu krajach zostały przeprowadzone za pomocą ankiety online. W Polsce zrealizowano badania na próbie 1768, a na Ukrainie na próbie 2291 respondentów. Wyniki badań pokazują, że młodzież jest zainteresowana problematyką pandemii, śledzi jej przebieg. Poziom obaw uczniów przed zarażeniem się koronawirusem jest niski. Młodzież cechuje się dobrostanem psychologicznym i preferuje aktywne strategie walki z zagrożeniem. Większość swojego czasu spędza w internecie. Wykorzystuje go głównie do zdalnej edukacji, komunikacji z rówieśnikami oraz rozrywki. W czasie offline uczniowie najczęściej słuchają muzyki, uprawiają aktywność fizyczną i spacerują po okolicy. Niewielka część respondentów angażuje się w pomoc seniorom. Negatywnie oceniają zdalne nauczanie i uważają, że kwarantanna nie wpłynie zbyt silnie na ich szanse życiowe.
\end{abstract}

Kluczowe słowa: praktyki społeczne, pandemia COVID-19, zdalne nauczanie, młodzież, Polska-Ukraina, sondaż.

\section{СОЦІАЛЬНІ ПРАКТИКИ В УМОВАХ ПАНДЕМІЇ COVID-19 СЕРЕД ПОЛЬСЬКОї ТА УКРАЇНСЬКОЇ МОЛОДІ}

Анотація: У Звіті за результатами соціологічного дослідження стосовно польської та української учнівської молоді під час перебування на карантині. Головною метою дослідження була спроба отримання відповіді на питання, як учні шкіл справляються із загрозою пандемії COVID-19. Чи є відмінності між польською та українською учнівською молоддю стосовно ставлення до пандемії, психологічного благополуччя, реакції на загрозу, використання Інтернету під час карантину, форм проведення вільного часу, оцінювання дистанційного навчання та його впливу на життєві та освітні перспективи молоді.

Дослідження в обох країнах реалізовано за допомогою онлайн опитування. У Польщі дослідження проводилося на вибірці 1 768, в Україні - на вибірці 2291 респондентів. Результати дослідження показують, що учнівська молодь $\epsilon$ зацікавлена проблематикою пандемії COVID-19, слідкує за ії̈ перебігом. Рівень страху в учнів стосовно зараження коронавірусом $€$ низьким. Учнівська молодь характеризується психологічним благополуччям, віддає перевагу активним стратегіям боротьби із загрозою. Більшу частину часу учні проводять в Інтернеті, використовують його в основному для дистанційного навчання, спілкування з однолітками та для розваг. Увільний часучні найчастіше слухають музику, займаються фізичною активністю, гуляють. Невелика частина респондентів допомагає людям похилого віку. Учні негативно оцінюють дистанційне навчання і вважають, що карантин не вплине досить суттєво на їхні життєві перспективи.

Ключові слова: соціальні практики, пандемія COVID-19, дистанційне навчання, молодь, Польща-Україна, опитування. 


\title{
SOCIAL PRACTICES IN THE COVID-19 PANDEMIC AMONG POLISH AND UKRAINIAN YOUTH
}

\begin{abstract}
The report presents the results of research into Polish and Ukrainian students staying at home during the lockdown. The main research goal was an attempt to answer the question how the students cope with the threat of the COVID-19 pandemic. The question whether there are any differences between Polish and Ukrainian students in terms of their attitudes towards the pandemic, their mental well-being, their reactions to the threat, the use of the Internet during the quarantine, forms of spending their free time as well as their evaluation of distance learning and its impact on their life and educational chances.

The research in both countries was conducted with the use of an on-line questionnaire. The research in Poland was conducted on the sample of 1768 respondents, whereas in Ukraine, 2291 respondents participated in the study. The results of the research indicate that the students are interested in the issues related to the pandemic and follow its course. The level of anxiety connected with contracting the coronavirus is low. The students have a good mental well-being and prefer active strategies for combating the threat. They spend most of their time in the Internet. They use it mostly for distance learning, communication with their peers and entertainment. While off-line, the students most often listen to music, do sports and walk around their neighbourhoods. A minor part of the respondents are involved in helping elderly people. They evaluate distance learning negatively and are convinced that the quarantine will fail to influence their life chances significantly.
\end{abstract}

Keywords: social practices, the COVID-19 pandemic, distance learning, youth, Poland-Ukraine, survey. 


\section{Spis treści}

8 2. Metodologia badań

9 3. Charakterystyka badanej zbiorowości

12 4. Zainteresowanie problematyką pandemii koronawirusa

13 5. Poziom lęku przed zarażeniem koronawirusem

17 6. Ocena działania władz w obliczu pandemii

18 7. Samopoczucie psychiczne

21 8. Życie w internecie

9. Życie poza siecią

30 10. Pomaganie seniorom

31 11. Młodzież w edukacji zdalnej

33 12. Zakończenie

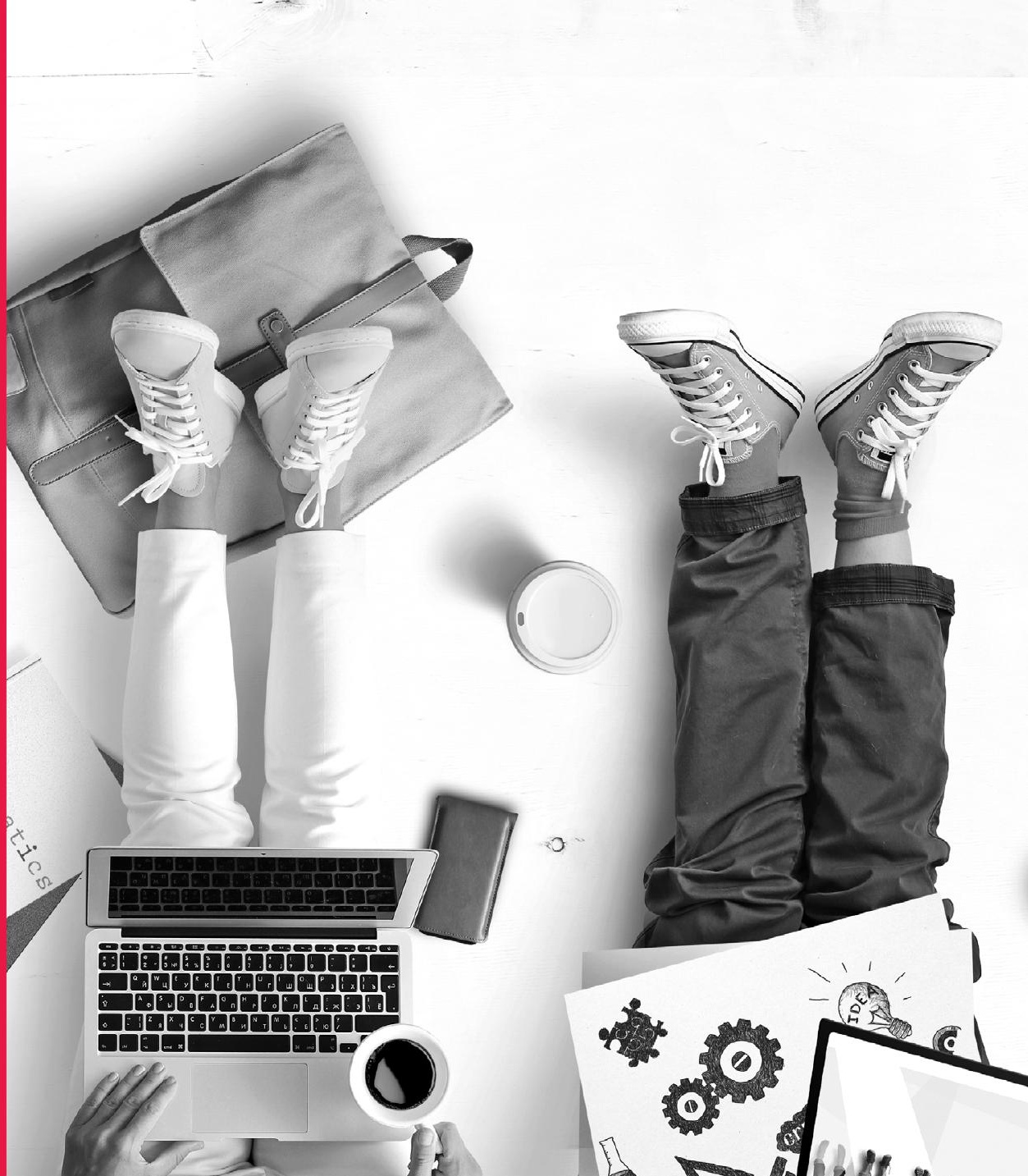




\section{Wstęp}

$\mathrm{N}$ a samym początku pandemii, kiedy jej śmiertelne żniwo zaczęło budzić przerażenie, rządy wszystkich państw świata rozłożyły parasol ochronny nad osobami starszymi. Wszyscy pamiętamy pomoc udzielaną im w codziennych zakupach przez wolontariuszy lub specjalne godziny, w których seniorzy sami mogli je robić, minimalizując kontakt $\mathrm{z}$ innymi osobami. Przywołane powyżej działania miały na celu obniżenie ryzyka zakażenia koronawirusem i w konsekwencji uratowanie ich przed śmiercią, ponieważ $\mathrm{w}$ przypadku zakażenia umierają głównie najstarsi (najsłabsi, z osłabioną odpornością). Widać było też w badaniach, np. CBOS-u, że większe obawy przed zarażeniem miały osoby starsze, w wieku $65+(71 \%)$ niż młodsze, w przedziale wiekowym od 18 do 34 lat (50\%) (Poczucie zagrożenia... 2020). Przedstawiciele najmłodszej generacji sądzili, że w razie zarażenia i tak uda się im wyzdrowieć, gdyż młody organizm jest $\mathrm{w}$ stanie sobie poradzić $\mathrm{z}$ wirusem podobnie łatwo jak ze zwykłą grypą. Dlatego wśród młodzieży nie uwidaczniały się lęki związane z pandemią COVID-19.

Życie w pandemii obwarowane jest poważnymi utrudnieniami, które spotykają całe społeczeństwo. Ograniczenie kontaktów społecznych, utrudnienia w dostępie do rozrywki i sportu mogą wywoływać napięcia i frustracje. Zjawisko to jest szczególnie widoczne wśród młodzieży, na co zwracają uwagę badacze z wielu państw. Przeprowadzone w Stanach Zjednoczonych badania Pew Research Center świadczą o tym, że najczęściej wysokiego i średniego poziomu stresu doświadczają osoby w grupie wieku 18-29 lat (61\%). W starszej generacji, 30-49 lat, wskaźniki stresu wynosiły 51\%, w kolejnej grupie, 50-64 lat $-47 \%$, a w najstarszej, $65+$, spadły do $38 \%$ [Schaeffer, Rainie 2020]. Badania porównawcze realizowane przed i po pojawieniu się COVID-19 na dużych próbach w Stanach Zjednoczonych oraz innych krajach pokazują, że wskaźniki zdrowia psychicznego obniżyły się we wszystkich grupach wiekowych, a poziom stresu wzrósł najbardziej w najmłodszych kategoriach wiekowych [Twenge, Joiner 2020; Huang, Zhao 2020].

Do podobnych konkluzji skłaniają wyniki badań realizowanych wśród polskiej młodzieży. Pokazują one, że pandemia pogłębiła i tak już nie najlepsze samopoczucie psychiczne młodzieży. Odsetek studentów zadowolonych z życia spadł z $80 \%$ do $74 \%$. Pierwszą falę badań zrealizowano na początku kwarantanny, drugą falę pod koniec semestru letniego. W ciągu trzech miesięcy kwarantanny i przerwy w tradycyjnych zajęciach doszło do pogorszenia kondycji psychicznej studentów. Uwidocznił się wzrost negatywnych emocji i objawów psychosomatycznych. Lęk i depresja, na co wskazuje wiele badań realizowanych na całym świecie, zdominowały sferę afektywną młodzieży. Potwierdzeniem powyższej diagnozy polskiej młodzieży były też odpowiedzi uzyskane na pytania dotyczące samopoczucia psychicznego. Większość studentów odczuwała niepokój (60\%), znudzenie (51\%), a także wyczerpanie (46\%), osamotnienie (34\%), smutek (34\%), gniew (25\%), lęk (19\%), apatię (19\%), żal (17\%), strach (15\%). Mimo że początkowo kwarantanna wydawała się dodatkowymi wakacjami, niewielu młodych wskazało na pozytywne efekty wywołane pandemią. Młodzież $\mathrm{w}$ niewielkim stopniu odczuwała zaciekawienie 
(10\%), spokój (5\%), ekscytację (2\%), radość (2\%) [Długosz 2020a]. Przykładem negatywnej reakcji uczniów na kwarantannę jest następująca wypowiedź ankietowanego: „No, wiadomo, że są gorsze i lepsze dni. Raz sobie radzę dobrze, a innym razem siedzę w kącie i płaczę... serio! Ze znajomymi mam tylko kontakt internetowy" [Długosz 2020]. O sytuacji młodzieży ukraińskiej w czasie pandemii możemy dowiedzieć się też $\mathrm{z}$ badań zrealizowanych na całej Ukrainie latem 2020 r. Prawie jedna trzecia badanych odczuła pogorszenie zdrowia psychicznego w czasie pandemii [Як живе... 2020].

W wyniku pandemii i towarzyszących jej problemów młodzież doznała poważnego uszczerbku na zdrowiu psychicznym. Cała sytuacja przypomina tę opisaną przez Karen Horney [1982] w niedługim czasie po wielkim kryzysie lat 30. XX w. Wtedy także zaobserwowano załamanie się wiary w sukces oraz pojawienie się neurotycznych reakcji na zagrażającą teraźniejszość i niepewną przyszłość. Zwrócono uwage, że duże znaczenie w powstawaniu nerwic mają kulturowe i społeczne czynniki, a nie tylko popędy biologiczne. Mówiono wówczas o neurotycznej osobowości. W obecnej sytuacji wywołanej pandemią można uznać za uprawnioną tezę, że oto na naszych oczach dochodzi do narodzin neurotycznej generacji. Antoni Kępiński [1986] pisał przed laty, że głównymi symptomami nerwicy są osłabienie i drażliwość. Przegląd wyników badań dotyczących wpływu pandemii na samopoczucie psychiczne wskazuje właśnie na wzrost poziomu lęku, depresji, obniżonej dynamiki życiowej, zmęczenia i zaburzenia nastrojów w skali globalnej.

O prawdziwości tej tezy może świadczyć wzrost społecznych niepokojów w czasach pandemii. Na ulicach miast w Polsce jak też na całym świecie widać było młodzież biorącą udział w protestach, rozruchach i ulicznych bijatykach ze służbami porządkowymi. Według ekspertów z Carnegie Endowment for International Peace od marca do października 2020 roku w 26 krajach odbyło się ponad 30 protestów przeciw restrykcjom związanym $\mathrm{z}$ epidemią koronawirusa. Wymienieni specjaliści twierdzą, że świat wkracza w erę masowych protestów wywołanych pandemią [Kluth 2020].

Celem niniejszego raportu jest przedstawienie wpływu kwarantanny na zdrowie psychiczne i życie młodzieży w tych trudnych czasach. Badania mają dać odpowiedź na pytanie o to, jak radzą sobie uczniowie szkół średnich z ograniczeniami wprowadzonymi przez rząd w obu krajach. Badania mają też na celu pokazanie, w jaki sposób pandemia, czyli zjawisko o charakterze globalnym, wpływa na młodzież w Polsce i na Ukrainie. Czy w sytuacji globalnego zagrożenia pojawiają się jakieś różnice w kondycji psychicznej i społecznych reakcjach, które wynikają z różnic kulturowych, społeczno-ekonomicznych, czy raczej dominują podobieństwa wynikające $\mathrm{z}$ globalizacji.

Raport jest zapisem sytuacji na samym początku kwarantanny. Pokazuje on pierwszą fazę radzenia sobie $z$ ograniczeniami przez uczniów szkół średnich. Polska część badań była prowadzona w ramach Krakowskiego Barometru Młodzieży realizowanego przez Centrum Badań Młodzieży Uniwersytetu Pedagogicznego dla Urzędu Miasta Krakowa'. We Lwowie badania realizowała prof. Olena Shyyan z Lwowskiego Regionalnego Instytutu Podyplomowej Pedagogicznej Oświaty.

Z ramienia Urzędu Miasta Krakowa pomocy w zbieraniu danych udzieliła pani Justyna Ożóg i pani Paulina Świątek-Wtorkiewicz. 


\section{Metodologia badań}

adania w obu miastach zostały zrealizowane za pomocą sondażu online. Metoda ta pozwala przeprowadzać je na dużych zbiorowościach. Sondaż polega na zadawaniu wybranej grupie osób pytań, które zazwyczaj mają charakter zamknięty i podlegają później ilościowej analizie danych. Została w nim wykorzystana ankieta internetowa CAWI. Sondaż za pośrednictwem internetu jest szybką, tanią metodą zbierania danych oraz zapewnia ankietowanym anonimowość. Wadą jego jest brak kontroli nad przebiegiem badania i osobami wypełniającymi ankietę. Inną niedoskonałością jest brak reprezentatywności, gdyż z sondażem online można docierać tylko do respondentów z dostępem do sieci. Mimo tych poważnych mankamentów w sytuacji kwarantanny metoda taka wydaje się najbardziej odpowiednia do prowadzenia tego typu badań. Warto też podkreślić, że w przypadku młodzieży mamy do czynienia ze stuprocentowym dostępem do nowoczesnych technologii w postaci smartfonów.

W Krakowie badania zrealizowano w dniach od 21.03 do 4.04.2020 r. We Lwowie czas realizacji badań przypadał na 27.04 do $17.05 .2020 \mathrm{r}$. W Krakowie przebadano próbę 1768 uczniów szkół średnich. We Lwowie uzyskano 2291 zwrotów prawidłowo wykonanych ankiet. $\mathrm{W}$ obu miastach link do ankiety był rozsyłany mailem do młodzieży szkół średnich. Próba do badań miała charakter celowy - była dobierana ze względu na dostępność badanych.
W obu miastach zajęcia szkolne zostały zawieszone mniej więcej $\mathrm{w}$ podobnym czasie tj. 12.03.2020 r. Badania w Krakowie zostały zrealizowane na samym początku kwarantanny. Sondaż we Lwowie został przeprowadzony w drugim miesiącu kwarantanny. Warto o tej różnicy pamiętać, gdyż może ona mieć wpływ na uzyskane rezultaty. Młodzież mogła się inaczej czuć i zachowywać na początku kwarantanny, traktując ten czas jako „koronaferie”, a zgoła odmienne reakcje i nastroje mogły się u niej pojawić po dwóch miesiącach kwarantanny, kiedy to doszło do deprywacji potrzeb.

Niemniej jednak należy zakładać, że w jednakowym stopniu kwarantanna wywołała wśród młodzieży podobne reakcje i postawy. Na podstawie uzyskanych odpowiedzi postaramy się przybliżyć postawy młodzieży w obu miastach.

Analizy będą dotyczyły zainteresowań zagrożeniem epidemiologicznym, a także oceny działań podejmowanych przez rząd i władze miasta w zakresie zabezpieczenia ludności. Badaniom poddano również praktyki związane $\mathrm{z}$ ochroną własnego zdrowia, kondycję psychiczną oraz reakcje na zagrożenie. W zakresie badań znalazła się też tematyka form spędzania czasu i sposoby wykorzystywania internetu podczas kwarantanny. Zbadano także postawy wobec zdalnego nauczania oraz wpływu kwarantanny na perspektywy życiowe młodzieży. 


\section{Charakterystyka badanej zbiorowości}

W obu krajach w sondażu częściej brały udział kobiety niż mężczyźni (wykres 1). Warto pamiętać, że w badaniach online (CAWI) kobiety są bardziej skłonne angażować się w wypełnianie ankiet i udzielanie odpowiedzi, co jest widoczne w wielu badaniach realizowanych w czasach pandemii.

Badana młodzież częściej pochodzi ze środowisk miejskich. W Polsce badania były prowadzone w Krakowie, na Ukrainie we Lwowie.
Na wykresie 2 widać, że na Ukrainie zdecydowana większość badanych uczniów pochodzi ze Lwowa. W Krakowie ponad 1/3 respondentów biorących udział w badaniu zamieszkuje poza miastem. Te różnice wynikają $\mathrm{z}$ odmienności systemów edukacyjnych w obu krajach. $\mathrm{Na}$ Ukrainie w obszarach wiejskich funkcjonują szkoły jedenastoklasowe, mające charakter szkół średnich. W Polsce szkoły średnie są w większości zlokalizowane w miastach.

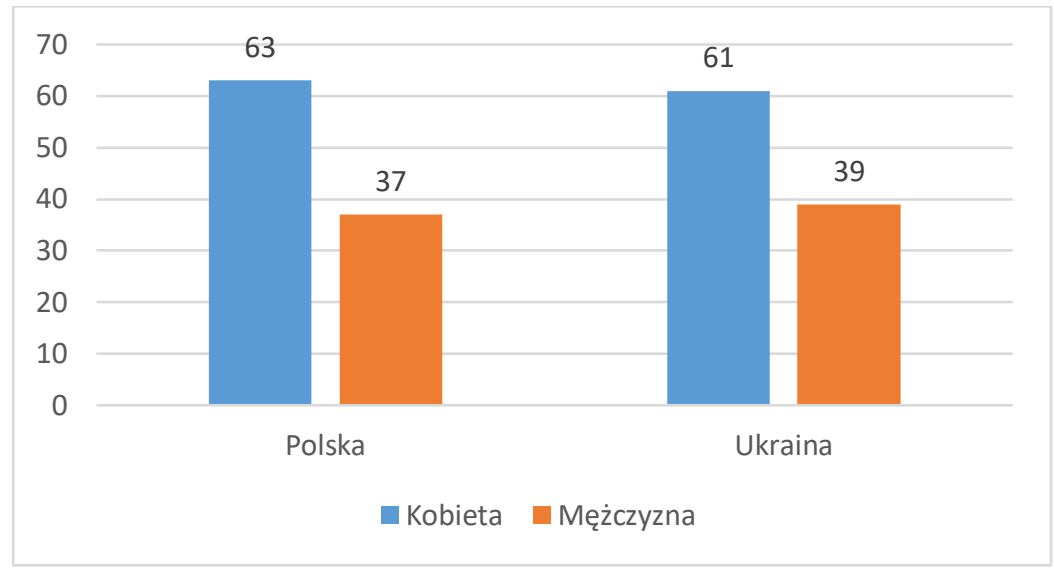

Wykres 1. Płeć badanych (\%)

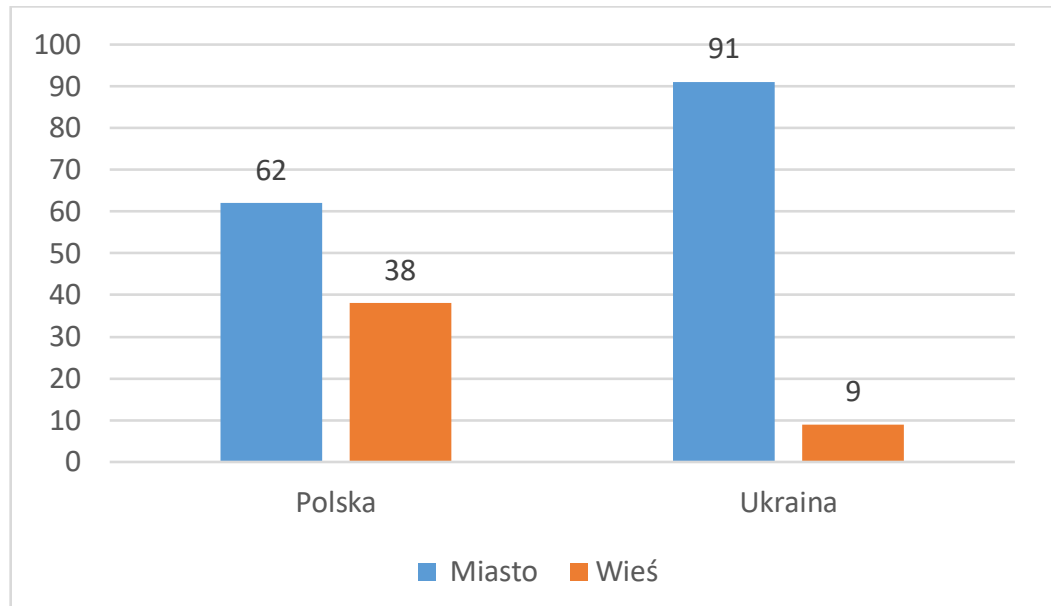

Wykres 2. Miejsce zamieszkania (\%) 
W przypadku oceny sytuacji materialnej zastosowano wskaźnik relatywny. Poproszono respondentów, aby ocenili swój poziom życia w stosunku do tego, jak żyją ich rówieśnicy (wykres 3). Z danych wynika, że zdecydowana większość uczniów umieszcza swoje warunki materialne na poziomie średnim. Ponadto w badanej próbie więcej jest tych, którzy uważają, że żyją na wyższym od innych poziomie niż na niższym. W obu krajach wyniki są bardzo podobne.

Kolejną charakteryzowaną zmienną jest stopień religijności młodzieży (wykres 4). Ponad połowa respondentów uważa się za wierzących, przy czym nieznacznie wyższy poziom wiary deklaruje ukraińska młodzież.
Wykres 5 (patrz s. 11) pokazuje, że większość badanej młodzieży posiada telefon komórkowy, stały dostęp do internetu, biurko do nauki. Młodzi ludzie zazwyczaj mają też w domu własne pokoje, a także laptopy, telewizory plazmowe, komputery stacjonarne. Rzadziej natomiast posiadają w swoich gospodarstwach działki rekreacyjne, dzieła sztuki i jachty.

W sytuacji nauczania na odległość brak dostępu do internetu w Polsce zadeklarowało $6 \%$, a na Ukrainie $14 \%$. Warto też podkreślić wniosek płynący z tego porównania: polska młodzież jest zasobniejsza w różne dobra trwałego użytku niż młodzież ukraińska. Wśród krakowskiej młodzieży częściej widoczne jest posiadanie w domu zmywarki do naczyń oraz

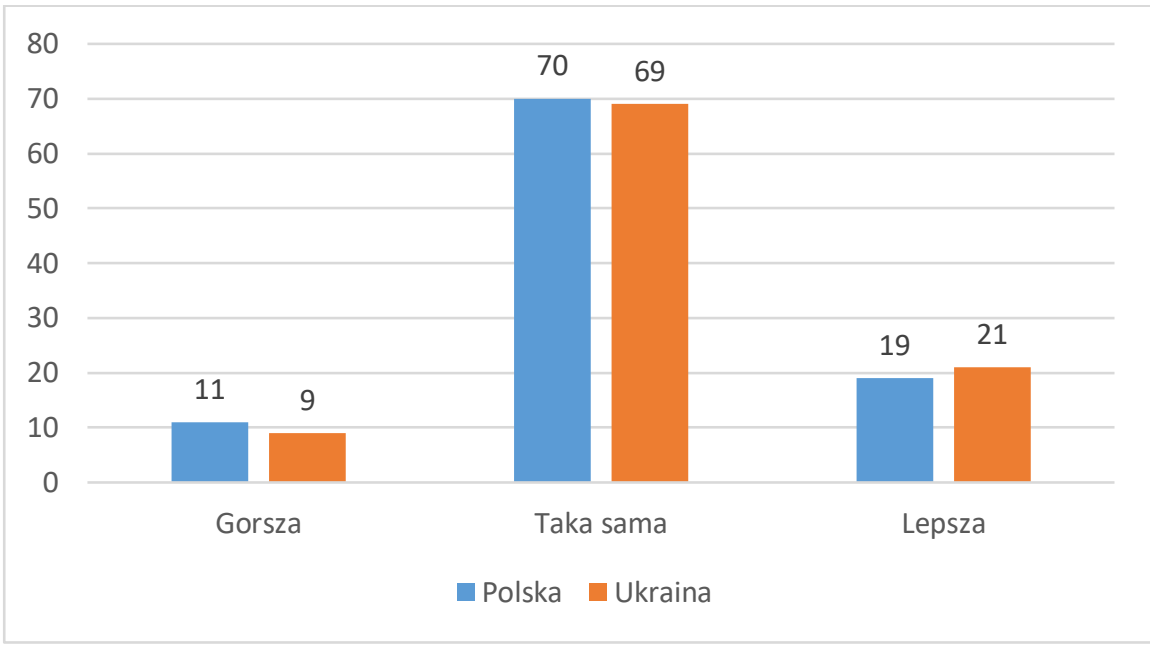

Wykres 3.

Ocena sytuacji materialnej (\%)

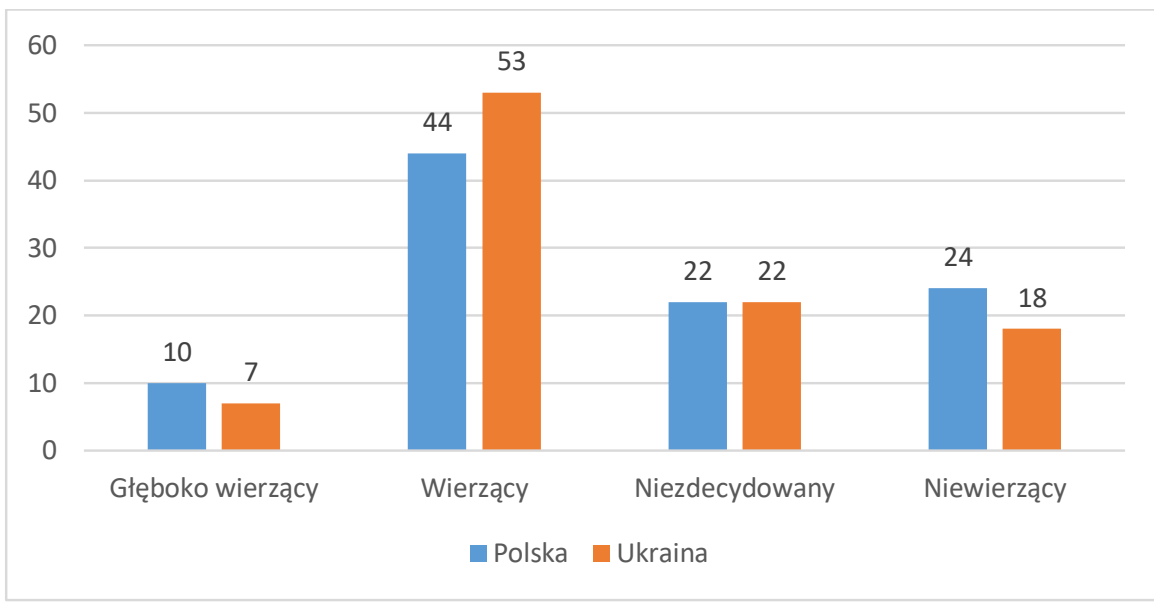

Wykres 4. 


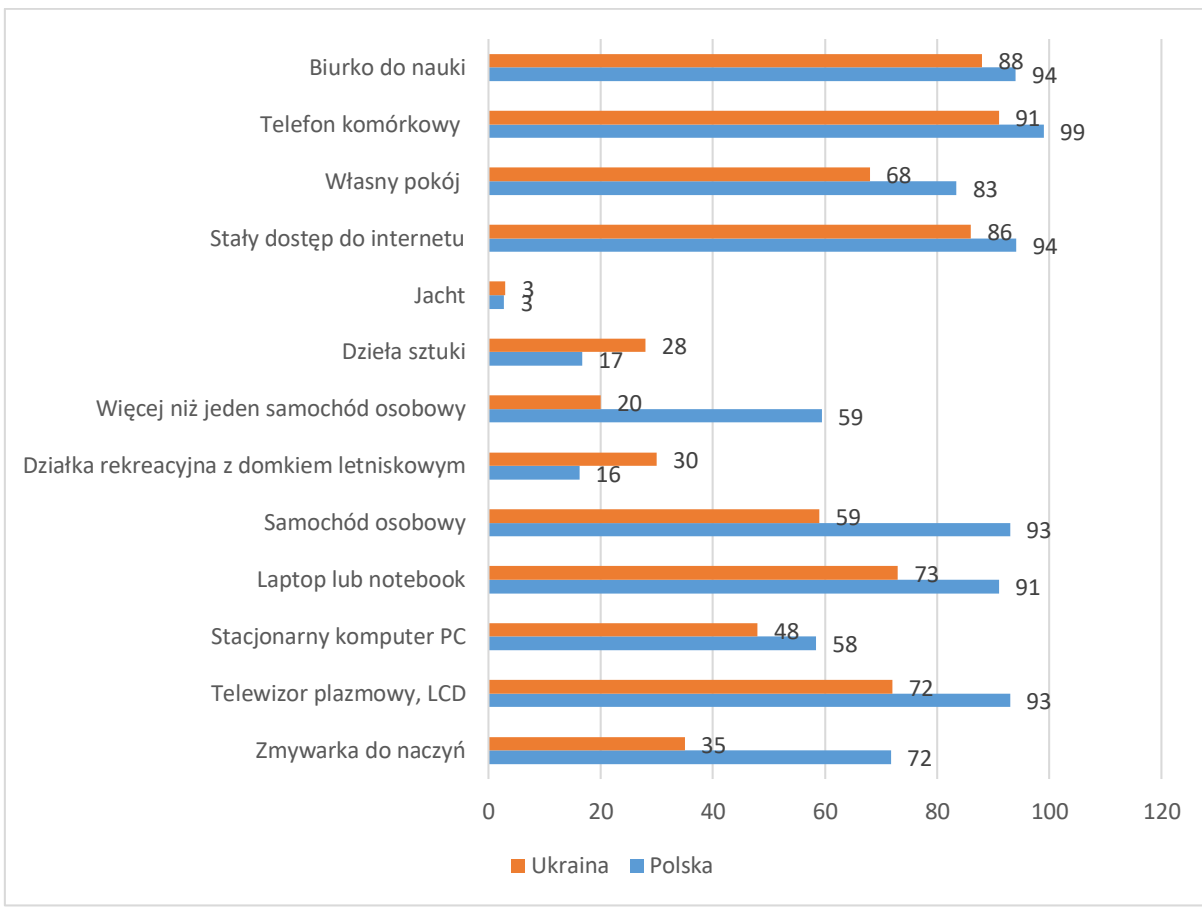

Wykres 5.

Wyposażenie gospodarstw domowych (\%)

więcej niż jednego samochodu. Młodzież w Polsce częściej też dysponuje laptopami niż młodzież ukraińska. Analogicznie jest w przypadku telewizorów plazmowych.

Kolejnym elementem wiedzy o ankietowanej grupie jest poziom wykształcenia matek i ojców (wykres 6). Wśród rodziców badanych uczniów dominuje wykształcenie wyższe, przy czym w Polsce lepsze wykształcenie częściej mają matki niż ojcowie. Na Ukrainie zaś nie ma tak wyraźnej różnicy między wykształceniem matek i ojców.

Podsumowując powyższe analizy, należy stwierdzić, że uczniowie szkół średnich w obu miastach cieszą się dobrymi warunkami materialnymi. Mają dostęp do telefonów oraz internetu, posiadają własne miejsca do nauki i pochodzą z dobrze wykształconych rodzin. Oznacza to, że badaniami została objęta młodzież reprezentująca wielkomiejską klasę średnią.

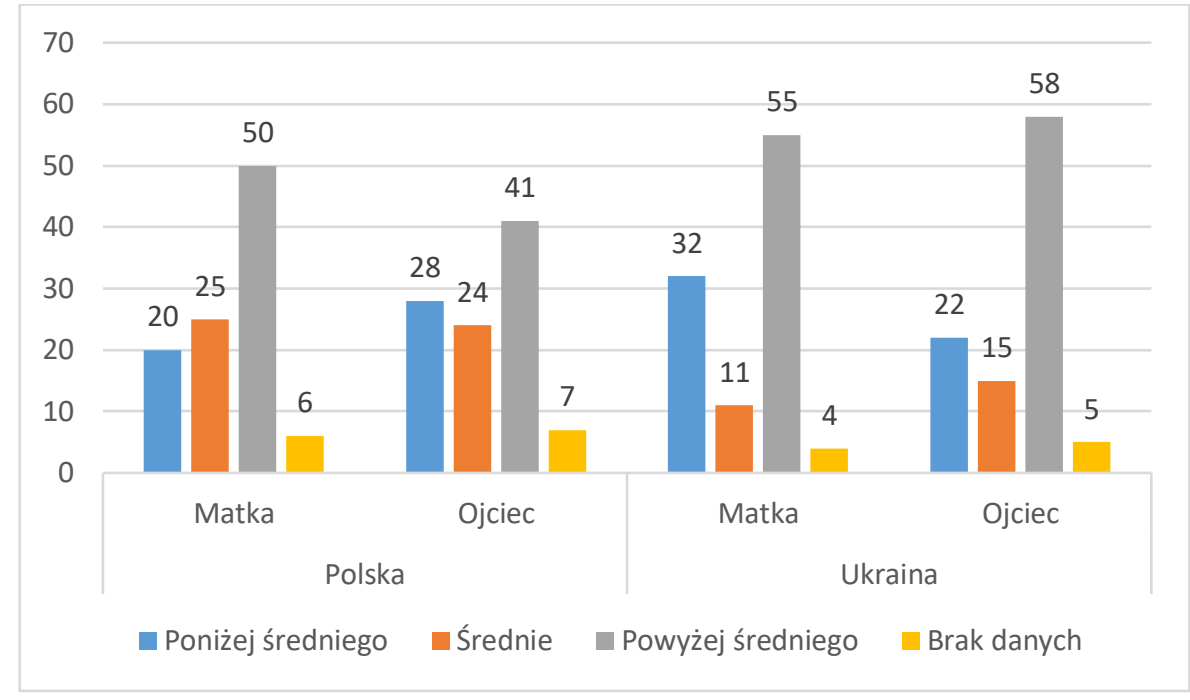

Wykres 6.

Poziom wykształcenia rodziców (\%) 


\section{Zainteresowanie problematyką pandemii koronawirusa}

$\mathrm{N}^{2}$

a początku analizy warto przyjrzeć się poziomowi zainteresowania pandemią wśród młodzieży (wykres 7). Rozkład odpowiedzi pokazuje, że prawie wszystkich badanych interesują informacje na temat koronawirusa i problemy z nim związane. Niewielu wskazało, że ta kwestia ich nie zajmuje. Z porównania wynika, że polska młodzież wykazuje nieco większe zainteresowanie pandemią niż młodzież ukraińska.

Potwierdzeniem tezy o masowym zainteresowaniu młodzieży pandemią koronawirusa jest odpowiedź na kolejne pytanie, w którym ankietowani mieli wskazać, czy znają aktualną liczbę zarażonych. Z danych zaprezentowanych na wykresie 8 wynika, że prawie wszyscy respondenci wiedzą, jaki jest aktualny stan pandemii w kraju. Świadczy to o tym, że respondenci interesują się związanym $\mathrm{z}$ nią zagrożeniem. Ponadto w warunkach zmasowanego medialnego przekazu na jego temat oraz ciągłego informowania o nowych zakażeniach trudno jest odciąć się od tych spraw. Być może śledzenie rozwoju skali zarażeń wynika z potrzeby kontroli poznawczej nad pandemią. W ten sposób uczniowie mogą ocenić, jaka jest skala zjawiska i poziom ich osobistego zagrożenia.
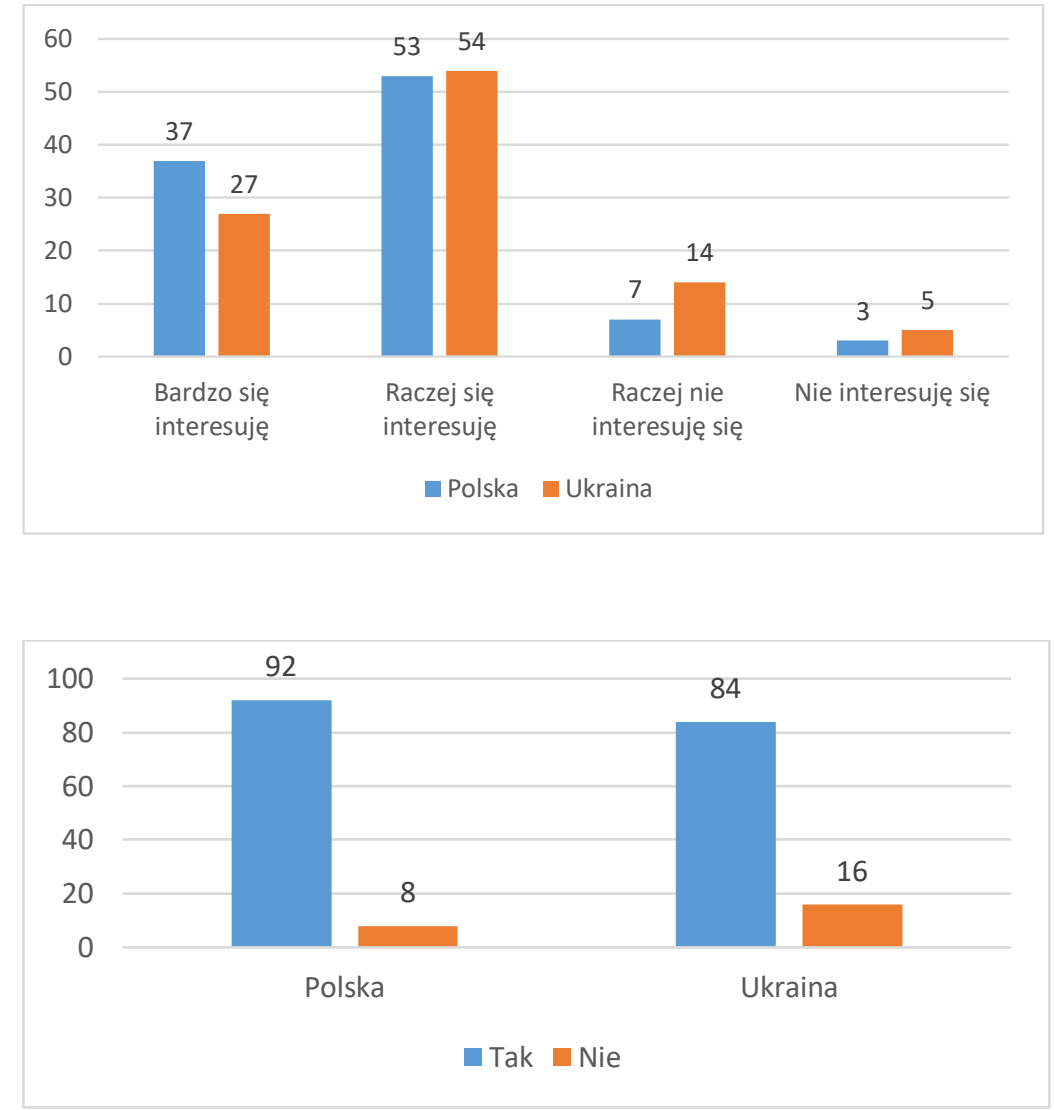

Wykres 7. Poziom zainteresowania tematem pandemii koronawirusa (\%)

Wykres 8. Wiedza na temat liczby zarażonych (\%) 


\section{Poziom lęku przed zarażeniem koronawirusem}

\section{Z} decydowana większość respondentów w obu krajach uważa, że koronawirus stanowi poważne zagrożenie dla mieszkańców (wykres 9). Porównania pokazują, że uczniowie są świadomi niebezpieczeństwa niesionego przez pandemię. Warto też podkreślić, że percepcja zagrożenia jest niemal identyczna w obu krajach.

Wykres 10 pokazuje, jak wygląda ocena ryzyka indywidulanego zarażenia się koronawirusem. Z danych wynika, że młodzież w Polsce i na Ukrainie rzadziej uważa, że koronawirus stanowi poważne zagrożenie, przy czym w Polsce co czwarty badany osobiście obawia się zarażenia, a na Ukrainie co trzeci. Polska młodzież w mniejszym stopniu niż ukraińska obawia się, że osobiście zostanie dotknięta problemem zakażenia i jego konsekwencjami.

Analizy pokazują panujące wśród młodzieży przekonanie, że epidemia wirusa jest groźniejsza dla innych osób niż dla nich samych. Jest to znane w psychologii zjawisko, nazywane nierealistycznym optymizmem (ang. unreali-
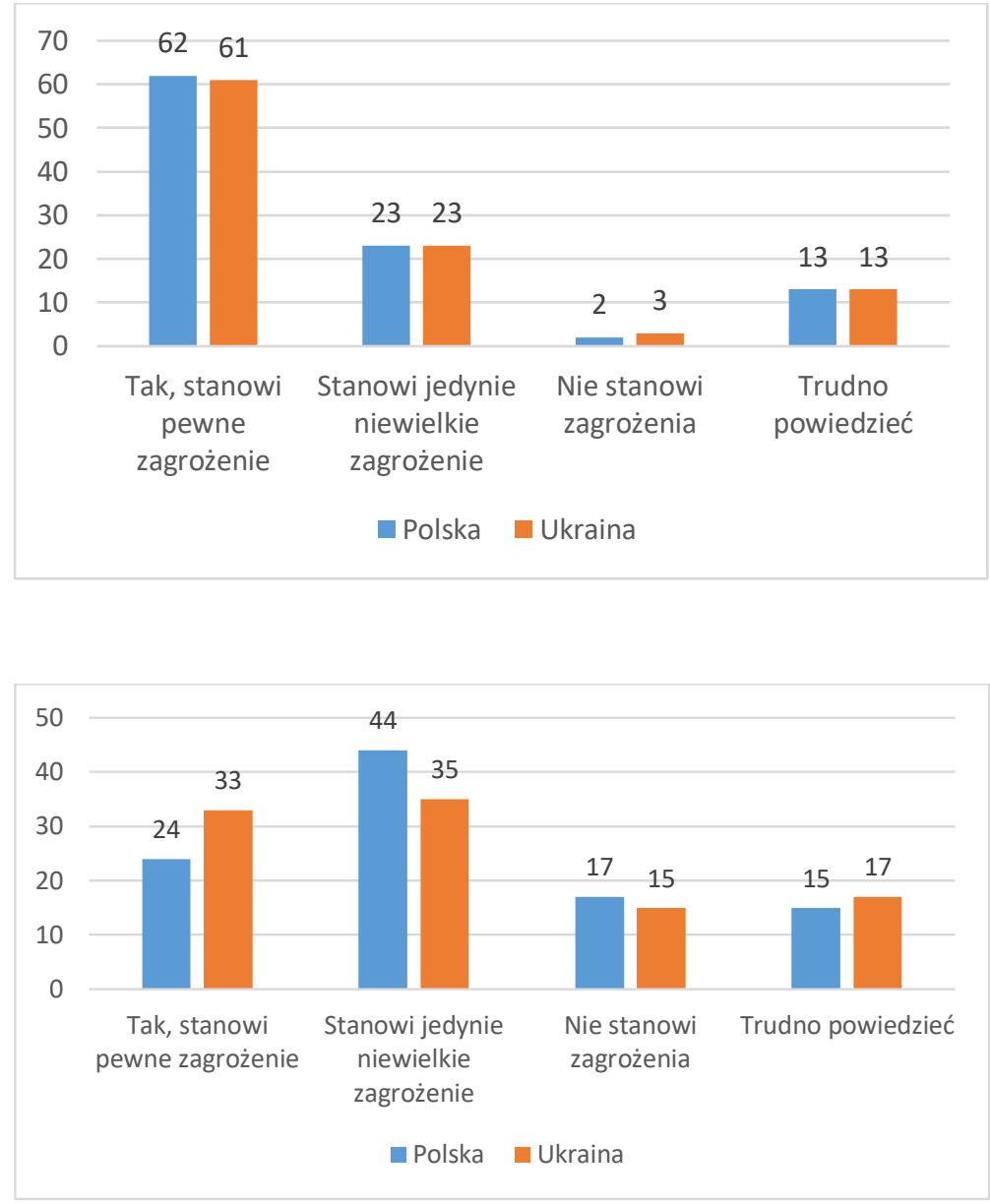

Wykres 9. Czy koronawirus stanowi zagrożenie dla życia mieszkańców kraju? (\%)
Wykres 10. Czy koronawirus stanowi zagrożenie dla Ciebie? (\%) 
stic optimism). Zjawisko to polega na istnieniu u większości ludzi silnego przekonania, że to raczej inni niż oni sami będą ofiarami nieszczęśliwych zrządzeń losu. Jednocześnie sądzą, że są bardziej niż inni predysponowani, by doświadczać zdarzeń pozytywnych.

Chcąc uzyskać precyzyjną odpowiedź na temat poziomu lęków w obliczu pandemii koronawirusa, zapytano też wprost o to, czy uczniowie boją się zarażenia (wykres 11). Rozkład odpowiedzi na to pytanie pokazuje, że u ponad $1 / 3$ respondentów można zidentyfikować lęk przed chorobą. Wśród około 1/5 badanych nie widać żadnych obaw. Większość respondentów objawia niewielką obawę przed zarażeniem. Poziom osobistych lęków przed zarażeniem rozkłada się podobnie w obu narodowościach.

$\mathrm{Na}$ wykresach 12 i 13 (patrz s. 15) został przedstawiony rozkład odpowiedzi dotyczących przewidywanego przez respondentów prawdopodobieństwa zarażenia się wirusem. Dane pokazują, że uczniowie raczej nie są przestraszeni ryzykiem zainfekowania. W obu krajach prawdopodobieństwo zarażenia się w skali od 0 do $100 \%$ szacują na około $30 \%$.

Potwierdzają się zatem wcześniejsze obserwacje, że poziom lęku przed zachorowaniem wśród uczniów jest niski. Warto jeszcze dodać, że szanse na zachorowanie krakowscy studenci szacowali średnio na 40\% [Długosz 2020a]. Z porównania tych wyników można wnioskować, że uczniowie szkół średnich w mniejszym stopniu niż studenci znajdują się pod wpływem stresu z powodu koronawirusa.

Wykres 14 (patrz s. 15) pokazuje związek między poziomem zainteresowania pandemia koronawirusa a poziomem lęku przed zakażaniem. Wyniki okazują się istotne statystycznie. Wskazują, że wraz ze wzrostem zainteresowania sytuacją epidemiczną rośnie u badanych szacowane prawdopodobieństwo zarażenia się. Być może szum informacyjny na temat chorych i ofiar śmiertelnych powoduje u badanych wrażenie, że zjawisko jest powszechne i nie ma przed nim żadnej ucieczki. Chłonięcie dużej liczby informacji na temat pandemii może prowadzić do zmniejszania się poczucia bezpieczeństwa. Psychologowie podkreślają, że jego obniżenie następuje poprzez ciągłe bombardowanie człowieka obrazami przemocy, gwałtu, katastrof, wojen, chorób czy też przez ciągłe przypominanie o ryzyku wystąpienia zagrożeń w przyszłości [Siek 1993]. Z taką właśnie sytuacją stykamy się obecnie, gdy media starają się zwiększyć swoją oglądalność, eksponując drastyczny obraz epidemii.

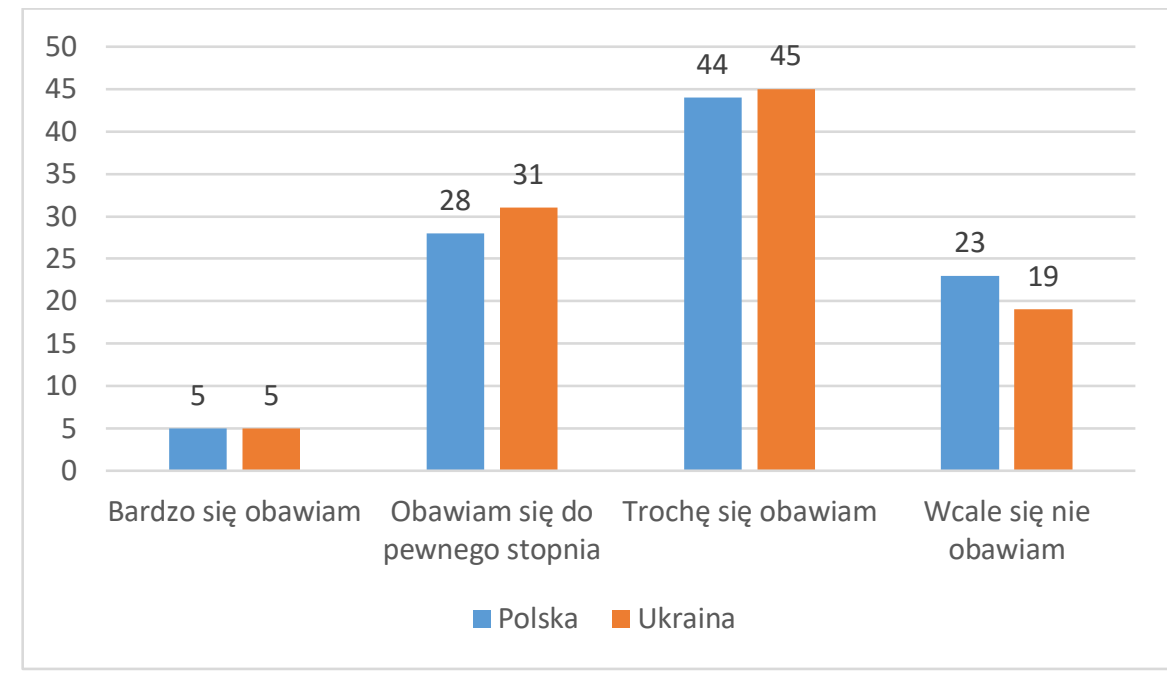

Wykres 11. Czy obawiasz sie zagrożenia koronawirusem? (\%) 


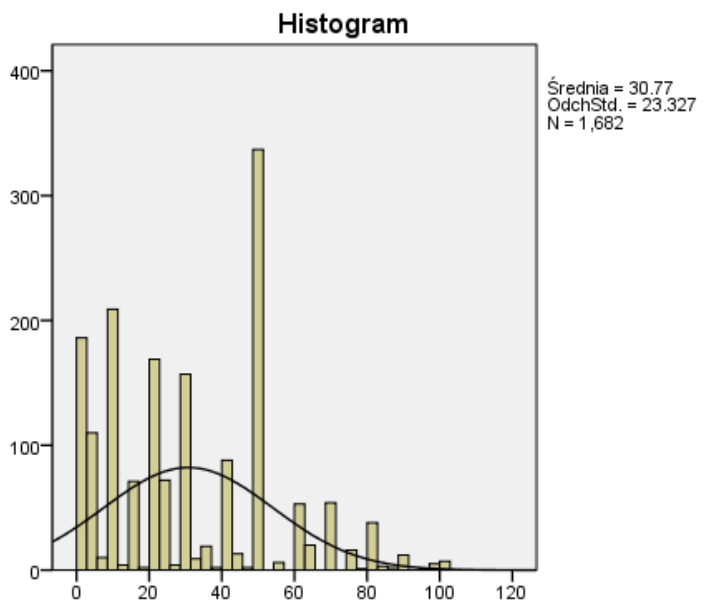

Wykres 12. Prawdopodobieństwo zarażenia się koronawirusem (Polska)

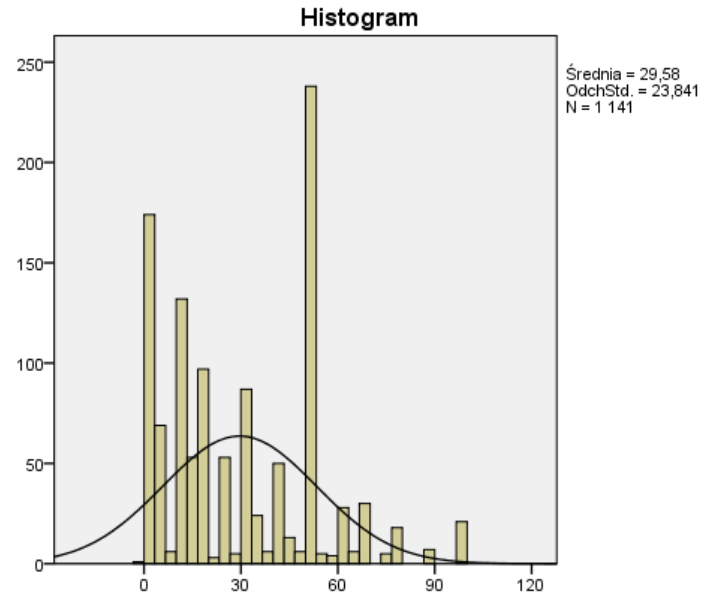

Wykres 13. Prawdopodobieństwo zarażenia się koronawirusem (Ukraina)

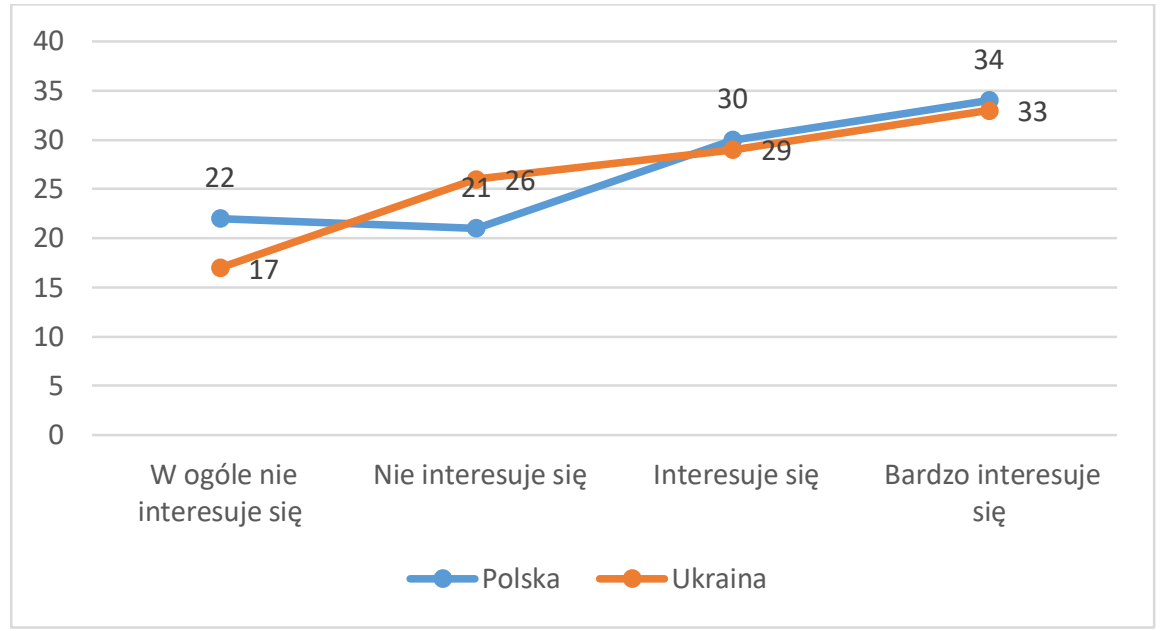

Wykres 14.

Związek między szacowanym prawdopodobieństwem zarażenia a poziomem zainteresowania epidemią

W celu zbadania wpływu zmiennych niezależnych na poziom obaw przed zarażeniem się został przygotowany indeks osobistych obaw przed zarażeniem (tabela 1). Indeks powstał z zestawienia odpowiedzi na dwa pytania dotyczące obaw przed koronawirusem. Połączono odpowiedź "tak, stanowi pewne zagrożenie” oraz „bardzo się obawiam”.

W wyniku zsumowania tych odpowiedzi uzyskano trzy wartości indeksu, 0 - brak silnych obaw, 1 - silna obawa pojawiła się raz, 2 - silna obawa pojawiła się dwukrotnie.
Tabela 1. Wartość indeksu osobistych obaw przed koronawirusem (\%)

\begin{tabular}{|l|c|c|c|}
\hline & $\mathbf{0}$ & $\mathbf{1}$ & $\mathbf{2}$ \\
\hline Polska & 75 & 22 & 3 \\
\hline Ukraina & 66 & 30 & 3 \\
\hline
\end{tabular}

Wyniki indeksu dla obu grup młodzieży pokazują, że poziom lęków przed koronawirusem wśród młodzieży jest niski, gdyż w polskiej i ukraińskiej próbie tylko 3\% badanych doznało dużego lęku. Średni poziom lęku widoczny był 
u co piątego ucznia w Polsce i co trzeciego na Ukrainie. Brak silnych obaw charakteryzuje większość badanej młodzieży.

Analiza korelacyjna, w której wykorzystano metodę $r$ Pearsona, pokazała, które ze zmiennych mają wpływ na intensywność odczuwanych obaw ${ }^{2}$. W obu krajach były to

2 Współczynniki korelacji są istotne statystycznie. dwie zmienne: religijność i zainteresowanie pandemią. W przypadku Polski dla pierwszej zmiennej wartość $r=0,100$, dla drugiej zmiennej $r=0,197$. Dla Ukrainy te wartości były wyższe. Dla religijności $r=0,147$, dla zainteresowania pandemią $r=0,219$. Analizy pokazują, że wraz ze wzrostem religijności i zainteresowania pandemią rośnie poziom osobistych obaw przed zarażeniem koronawirusem. 


\section{Ocena działania władz w obliczu pandemii}

olejne pytania ankiety dotyczyły oceny funkcjonowania państwa i jego służb $\mathrm{w}$ warunkach zagrożenia pandemią koronawirusa (wykres 15). Na pytanie o działania rządu i służb w celu zabezpieczenia kraju przed epidemią koronawirusa uzyskano różne odpowiedzi w obu krajach. W Polsce oceny pozytywne przeważały nad negatywnymi. Na Ukrainie zaś uczniowie częściej oceniali dokonania władz negatywnie.
Analizy wykazały też, że w Polsce ocena rządu była skorelowana $\mathrm{z}$ religijnością $(\mathrm{r}=0,121)$. Należy tę zależność rozumieć tak, że osoby religijne, czyli prawdopodobnie o poglądach konserwatywnych, lepiej oceniały działania rządu niż osoby niereligijne, częściej reprezentujące opcje liberalne.

W przypadku polskiej młodzieży na ocene rządu miała zatem wpływ orientacja polityczna. Na Ukrainie nie odnotowano żadnych związków między zmiennymi niezależnymi a oceną władz.

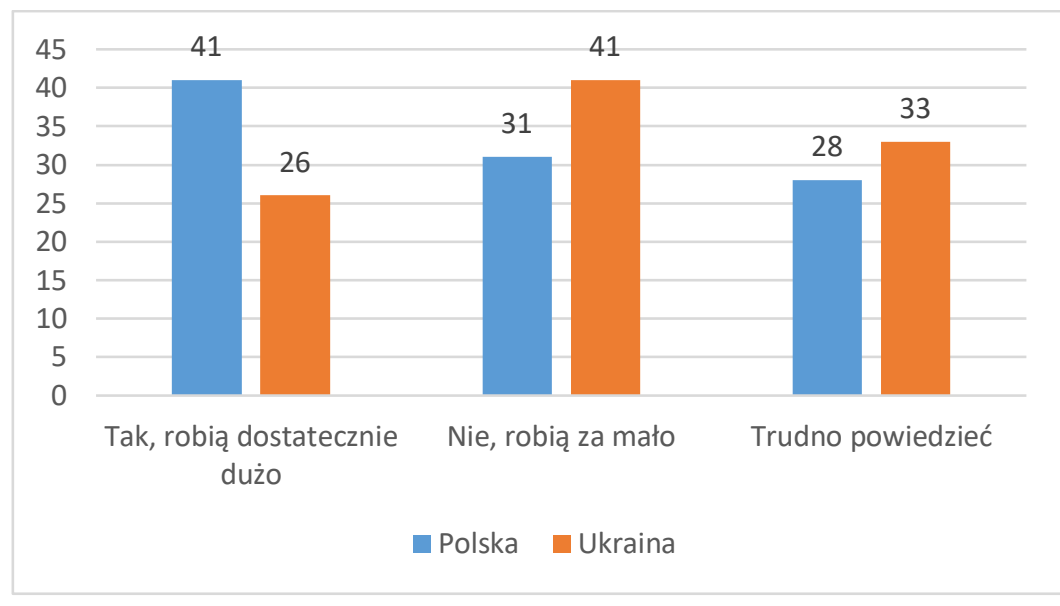

Wykres 15. Ocena funkcjonowania rządu i odpowiednich służb w walce z pandemią koronawirusa (\%) 


\section{Samopoczucie psychiczne}

andemia koronawirusa i szybki przyrost zakażeń w populacji, a przede wszystkim wysokie ryzyko śmiertelności mogą wywoływać społeczne lęki i napięcia psychiczne. Stres jest też wzmagany zmianą dotychczasowego trybu życia i narastającą niepewnością jutra. Nie znamy bowiem jeszcze ekonomicznych ani społecznych skutków pandemii. Zwłaszcza młodzież szkolna, przebywająca dłuższy czas w warunkach domowej kwarantanny, może odczuwać frustrację i napięcia wynikające $\mathrm{z}$ deprywacji potrzeb. W niekorzystnej sytuacji mogą się znajdować uczniowie, którzy w tym roku (2020) kończą szkołę i zdają egzaminy końcowe. Kolejne pytania miały na celu zbadanie, w jaki sposób uczniowie radzą sobie $z$ kwarantanną oraz czy wpłynęła ona na obniżenie poziomu ich dobrostanu psychicznego.

Dane na wykresie 16 pokazują, że większość respondentów jest zadowolona z życia. Wyższy poziom zadowolenia widoczny jest wśród ukraińskiej młodzieży (78\%) niż polskiej (66\%). Co piąty uczeń wyraził swoje niezadowolenie z życia. Uzyskane wyniki mogą oznaczać, że dobrostan psychiczny jest cechą głębszą i nie poddaje się negatywnemu wpływowi drobnych kłopotów i trudności codziennych.

Zgodnie z cebulową teorią szczęścia [Czapiński 2012] poczucie szczęścia jest cechą głębszą. Wyróżnia się swego rodzaju atraktor szczęścia, który jest odporny na zewnętrzne zakłócenia. Jego rolą jest mobilizowanie człowieka do działań poprawiających jego obiektywną sytuację życiową. W obliczu stresu i zagrożeń ludzie przejawiają wolę walki i mogą zabiegać o poprawę warunków własnego bytowania. W tym kontekście dobrostan w warunkach zarazy miałby więc funkcję adaptacyjną i pozwalałby młodzieży podejmować walkę z zagrożeniem. Gdyby sytuacja była odwrotna i większość młodych ludzi żyłaby w lęku i rozpaczy, wówczas stawianie czoła pandemii byłoby niemożliwe.

Może być też tak, że w warunkach większego zagrożenia człowiek przestaje zwracać uwagę na drobniejsze problemy, które zazwyczaj obniżają mu nastrój. Koncentruje się na rzeczach istotnych i docenia to, czego wcześniej nie uwzględ-

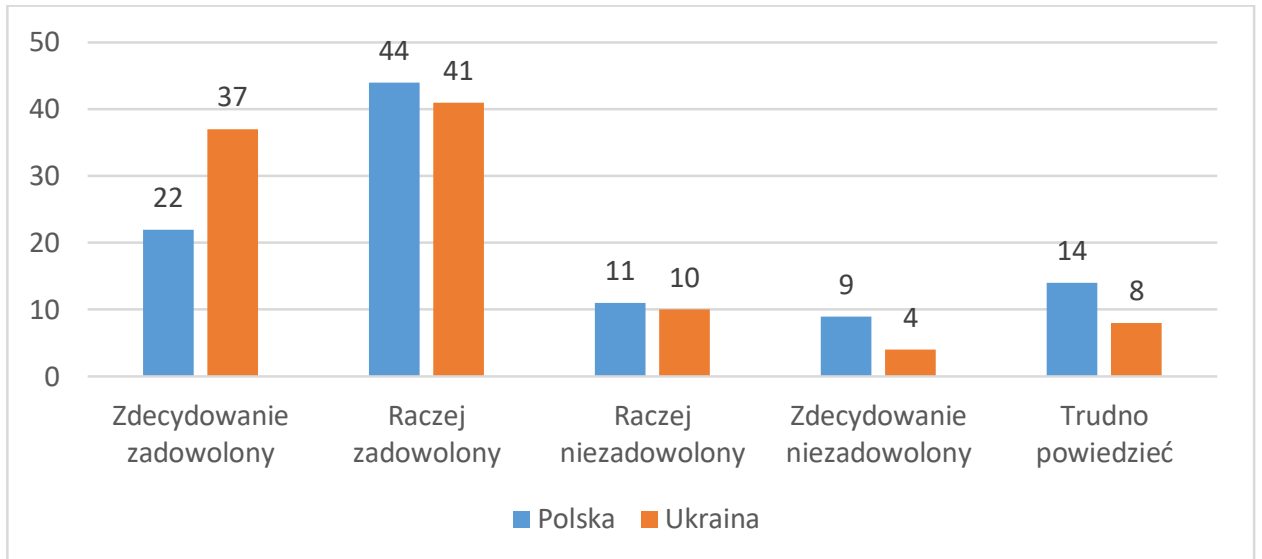

Wykres 16. Poziom zadowolenia z życia (\%) 
niał, stąd też ostateczny bilans emocjonalny okazuje się pozytywny.

Analiza korelacyjna pokazała, że jest kilka zmiennych, które są skorelowane z zadowoleniem z życia. W Polsce dobrostan skorelowany jest ze szkolnymi osiągnieciami $(\mathrm{r}=0,114)$, religijnością $(\mathrm{r}=0,155)$, sytuacją materialną $(\mathrm{r}=0,185)$, zainteresowaniem pandemią $(r=0,115)$ oraz oceną poziomu zagrożenia przez pandemię $(\mathrm{r}=0,102)$. Zadowolenie z życia rośnie wraz ze szkolnymi osiągnięciami, religijnością i lepszą sytuacją materialną. Lepiej oceniają swoje szczęście uczniowie, którzy wykazują większe zainteresowanie pandemią oraz dostrzegają związane z nią niebezpieczeństwa.

Podobne zależności pojawiają się na Ukrainie. Wśród badanych uczniów zadowolenie z życia rośnie wraz ze wzrostem religijności $(r=0,202)$, a także podnosi się jego poziom u uczniów lepiej oceniających swoją sytuację materialną.
Kolejne odpowiedzi pokazują, w jaki sposób uczniowie reagują na pojawiające się zagrożenie. Obserwacje pozwalają także oszacować strategie młodzieży w radzeniu sobie ze stresem wywołanym przez epidemię (wykres 17).

Młodzież najczęściej podejmuje działania, które mają na celu odcięcie się od strumienia myśli związanych z pandemią koronawirusa. Jedni oddają się hobby lub np. czytają książki. Inni, co pokazały akcje w mediach społecznościowych (Facebook), zamieszczają swoje zdjęcia z dzieciństwa, aby wspólnie powspominać i oderwać się od myśli o niebezpieczeństwie. Kolejną częstą strategią jest mobilizacja i przeciwstawienie się zagrożeniu.

Popularną metodą jest także racjonalizacja, która polega na szukaniu pozytywów i koncentracji na dobrych stronach życia. Widać zatem, że młodzi przyjmują strategię „słodkiej cytryny”,

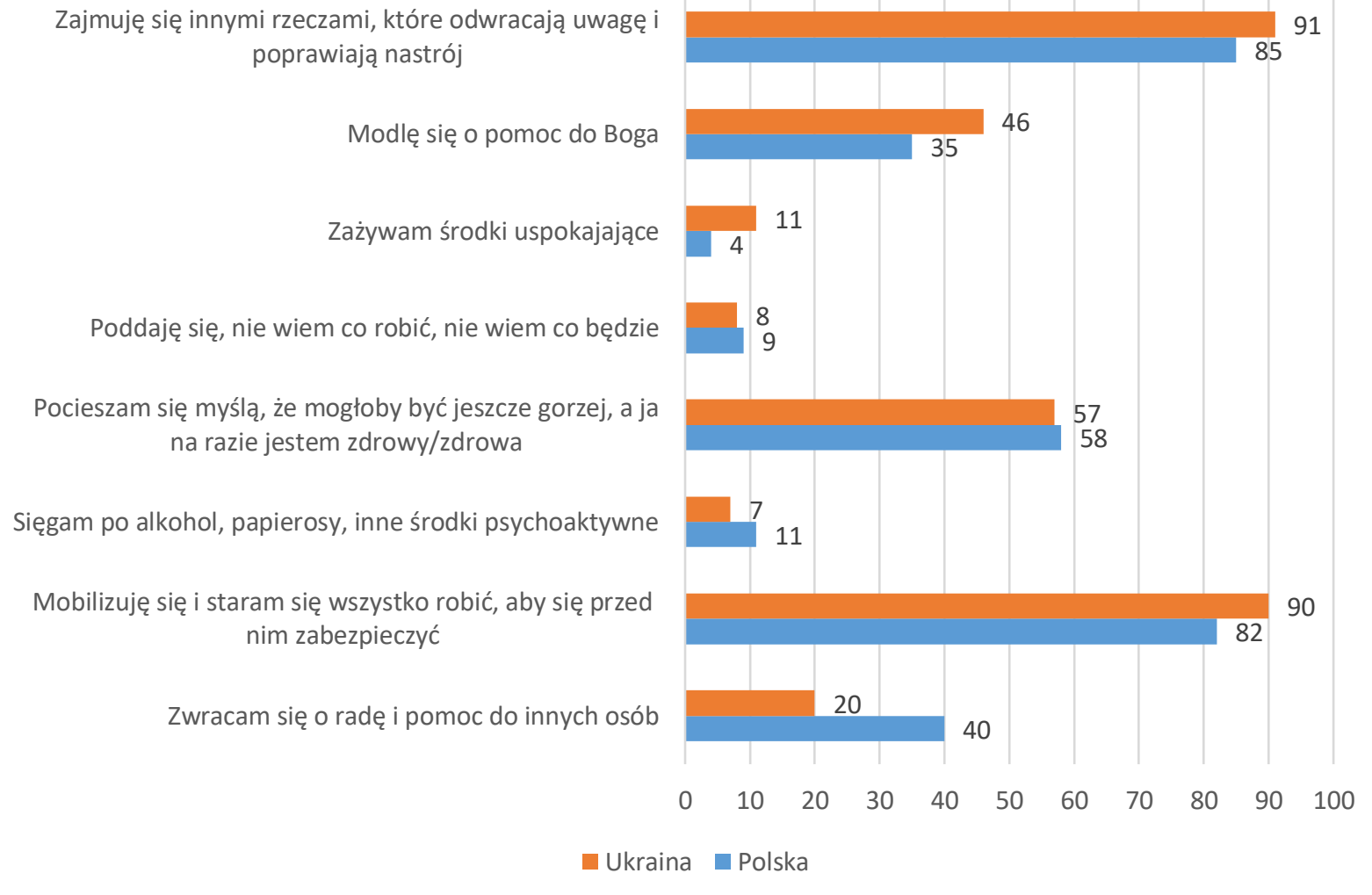

Wykres 17. W jaki sposób starasz się zachowywać w sytuacji zagrożenia koronawirusem w Polsce? (\%) 
Tabela 2. Wyniki analizy korelacyjnej dla strategii radzenia sobie z pandemią ${ }^{3}$

\begin{tabular}{|c|c|}
\hline Polska & Ukraina \\
\hline $\begin{array}{l}\text { Zwracanie się o radę i pomoc częściej charakteryzuje uczniów bardziej zain- } \\
\text { teresowanych pandemią }(r=0,119) \text { oraz tych, którzy twierdzą, że jest to } \\
\text { poważny problem dla Polaków }(r=0,118) \text {. }\end{array}$ & $\begin{array}{l}\text { Zwracanie się o pomoc do innych osób charakterystyczne jest dla uczniów } \\
\text { bardziej obawiających się zarażenia }(r=0,130) \text { oraz religijnych }(r=0,100) \text {. }\end{array}$ \\
\hline $\begin{array}{l}\text { Mobilizacja jest charakterystyczna dla uczniów zorientowanych w liczbie } \\
\text { zarażonych }(r=0,111) \text {, interesujących się pandemią }(r=0,221) \text {, uważają- } \\
\text { cych, że koronawirus jest zagrożeniem dla Polaków }(r=0,147) \text { oraz że jest } \\
\text { zagrożeniem dla respondentów ( } r=0,144) \text {. Częściej taką strategię wybierają } \\
\text { dziewczęta }(r=0,165) \text {. }\end{array}$ & $\begin{array}{l}\text { Mobilizacja częstsza jest wśród uczniów zainteresowanych pandemią } \\
(r=0,178) \text {, uważających, że koronawirus jest poważnym zagrożeniem } \\
\text { dla Ukraińców }(r=0,133) \text {, jak też dla jest zagrożeniem dla respondentów } \\
(r=0,114) \text {. Czéściej tę strategię prezentują respondenci obawiający się } \\
\text { zarażenia }(r=0,226) \text { oraz częśiej są to dziewczęta }(r=0,133) \text {. }\end{array}$ \\
\hline $\begin{array}{l}\text { Sięganie po alkohol, papierosy i środki psychoaktywne częściej się pojawia } \\
\text { wśród uczniów niezadowolonych zżycia }(r=0,115) \text { i mniej religijnych }(r=0,117) \text {. }\end{array}$ & $\begin{array}{l}\text { Sięganie po alkohol, papierosy iśrodki psychoaktywne częściej się pojawia wśród } \\
\text { uczniów niezainteresowanych pandemią }(r=0,138) \text { i mniej religijnych }(r=0,116) \text {. }\end{array}$ \\
\hline $\begin{array}{l}\text { Pocieszanie się, że mogłoby być gorzej charakteryzuje częściej dziewczęta } \\
(r=0,177) \text { i uczniów technikum }(r=0,129) \text {. Uczniowie ci mają też gorzej } \\
\text { wykształconych rodziców }(r=0,133) \text {. }\end{array}$ & $\begin{array}{l}\text { Pocieszanie się, że mogłoby być gorzej charakteryzuje częściej uczniów } \\
\text { obawiających się zarażenia }(r=0,100) \text {. }\end{array}$ \\
\hline $\begin{array}{l}\text { Bierne uleganie rozwojowi wypadków, poddawanie się częściej pojawia } \\
\text { się wśród respondentów niezadowolonych z życia }(r=0,148) \text {, oraz wśród } \\
\text { dziewcząt }(r=0,118) \text {. }\end{array}$ & $\begin{array}{l}\text { Bierne uleganie rozwojowi wypadków, poddawanie się częściej pojawia się } \\
\text { wśród respondentów niezadowolonych z życia }(r=0,100) \text { oraz obawiających } \\
\text { się zarażenia }(r=0,100) \text {. }\end{array}$ \\
\hline \multicolumn{2}{|l|}{$\begin{array}{l}\text { Zażywanie środków uspokajających częstsze jest u uczniów niezadowolonych } \\
\text { z życia }(r=0,131) \text {. }\end{array}$} \\
\hline \multirow[t]{2}{*}{$\begin{array}{l}\text { Modlitwa o wsparcie częściej pojawia się wśród zadowolonych z życia } \\
(\mathrm{r}=0,116) \text {, mieszkających poza Krakowem }(\mathrm{r}=0,109) \text {, bardziej religijnych } \\
(\mathrm{r}=0,616) \text { oraz dobrze oceniających rząd w walce } z \text { koronawirusem }(\mathrm{r}=0,116) \text {. }\end{array}$} & $\begin{array}{l}\text { Modlitwa o wsparcie częściej pojawia się wśród zadowolonych z życia } \\
(r=0,163) \text {, zainteresowanych pandemią }(r=0,150) \text {, uważających, że koro- } \\
\text { nawirus jest osobistym zagrożeniem }(r=0,114) \text {, obawiających się zarażenia } \\
(r=0,270) \text {, pomagających seniorom }(r=0,110) \text { i deklarujących wyższy } \\
\text { poziom religijności }(r=0,567) \text {. }\end{array}$ \\
\hline & $\begin{array}{l}\text { Innymi rzeczami, odwracającymi uwagę od pandemii, zajmują się głównie } \\
\text { uczniowie zadowoleni zżycia }(r=0,116) \text {, zainteresowani pandemią }(r=0,120) \\
\text { i częściej obawiający się zarażenia }(r=0,115) \text {. }\end{array}$ \\
\hline
\end{tabular}

wmawiając sobie, że ,jeszcze nie jest tak źle”. Część uczniów szuka wsparcia społecznego u innych osób oraz zwraca się z modlitwą o pomoc do Boga.

Wyniki analiz pokazują, że ankietowani w niewielkim stopniu podejmują działania polegające na zmniejszeniu napięcia poprzez spożywanie substancji psychoaktywnych czy leków. Niewielu też deklaruje, że stosuje strategie eskapistyczne, polegające na rezygnacji i podaniu się losowi, przypadkowi.

Porównanie obu grup młodzieży pokazuje, że w niektórych działaniach pojawiają się pod tym względem różnice. Polska młodzież częściej niż młodzież ukraińska zwraca się o radę i pomoc do innych osób (różnica 20 punktów procentowych). Ukraińska

3 Wszystkie współczynniki korelacji r Pearsona są istotne statystycznie. młodzież zaś częściej niż polska modli się o pomoc do Boga (różnica 11 punktów procentowych). Młodzi Ukraińcy częściej też starają się mobilizować i dobrze przygotować do walki z zagrożeniem.

Analiza danych pokazuje, że różne działania są podejmowane głównie przez uczniów poddanych stresowi pandemii. $\mathrm{Na}$ jej podstawie można też stwierdzić, że uczniowie na wyższym poziomie dobrostanu psychicznego oraz bardziej religijni częściej przejawiają aktywne strategie walki z zagrożeniem koronawirusem, a ci mniej religijni oraz niezadowoleni z życia przejawiają strategie bierne. Tym samym można skonstatować, że w prowadzonych analizach doszło do potwierdzenia hipotezy dotyczącej adaptacyjnej roli zadowolenia z życia. Dane wskazują, że dobrostan ma za zadanie mobilizować do działania i radzenia sobie w sytuacjach trudnych. 


\section{8. Życie w internecie}

W

raz z zawieszeniem zajęć w szkołach oraz odcięciem uczniów od rozrywek i kontaktów towarzyskich nagle zwiększyła się ilość ich wolnego czasu. Kolejnym zagadnieniem poddanym badaniu są zatem sposoby spędzania czasu wolnego.

Wyniki badań na wykresie 18 pokazują, że po wprowadzeniu lockdownu użytkownicy sieci przenieśli swoje życie społeczne do wirtualnej rzeczywistości. Respondenci spędzają średnio minimalnie od dwóch, a maksymalnie nawet do ponad ośmiu godzin dziennie $\mathrm{w}$ internecie.

Oznacza to, że uczniowie raczej lokują się w górnych granicach ilości czasu spędzanego $\mathrm{w}$ internecie. Obserwacje potwierdzają więc hipotezę, że uczniowie starają się zaspokoić swoje potrzeby w cyfrowej rzeczywistości. Porównanie wyników z obu krajów pokazuje, że czas przeznaczany na surfowanie $\mathrm{w}$ sieci jest identyczny. Nastolatek ma podobne zwyczaje niezależne od kraju pochodzenia. Jest on wytworem globalnej kultury cyfrowej.

Wyniki analizy korelacyjnej pokazują, że w Polsce więcej czasu w internecie spędzają uczniowie technikum niż liceum $(\mathrm{r}=0,116)$. Dłużej przebywają w cyfrowej rzeczywistości osoby mniej religijne $(\mathrm{r}=0,175)$ oraz uczniowie, których matki są gorzej wykształcone $(\mathrm{r}=0,100)$. Obserwuje się też, że im niższe stopnie uzyskuje uczeń, tym więcej czasu przeznacza na internet. Wśród młodzieży ukraińskiej głównym wyznacznikiem czasu spędzonego w internecie jest religijność. Im niższa religijność, tym więcej czasu uczniowie korzystają $\mathrm{z}$ internetu $(\mathrm{r}=0,202)$.

Wiadomo zatem, że młodzież sporo czasu spędza w internecie. Można więc stwierdzić, że w czasie kwarantanny to właśnie do tego medium przeniosło się życie młodzieży. W kolej-

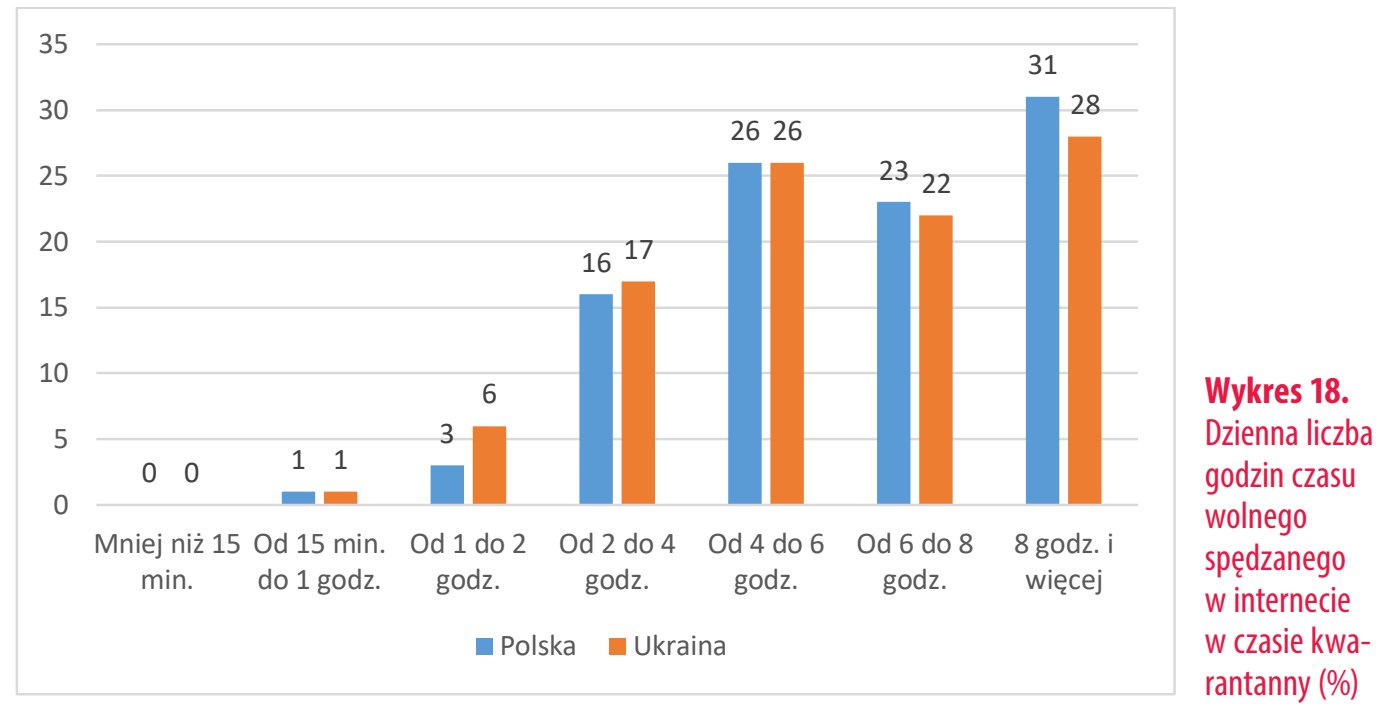


nych analizach zostanie pokazane to, $\mathrm{w}$ jaki sposób spędzają tam czas, na co poświęcają go, surfując w sieci.

$\mathrm{Z}$ danych zaprezentowanych na wykresie 19 wynika, że aktywność młodzieży w internecie koncentruje się na utrzymywaniu kontaktów ze znajomymi za pośrednictwem komunikatorów oraz serwisów społecznościowych. Drugą ważną czynnością widoczną u uczniów jest rozwój własnych zainteresowań za pomocą narzędzi cyfrowych. Internet wykorzystywany jest też do zdobywania wiedzy i uczestnictwa w zdalnym nauczaniu. Trzecią jego funkcją jest rozrywka. Młodzież wykorzystuje internet do słuchania muzyki i oglądania filmów.

Rzadziej aktywność w internecie sprowadza się do tworzenia swoich zdjęć, grafik. Niechętnie badani wykorzystują cyfrowe technologie do załatwiania spraw urzędowych, prowadzenia własnego bloga, udziału w dyskusjach, udziału $\mathrm{w}$ grach online czy robienia zakupów.

Reasumując, można stwierdzić, że młodzież szkolna jest raczej biernym niż czynnym użytkownikiem internetu. W warunkach zagrożenia pandemią koronawirusa wykorzystuje go głównie do kontaktów społecznych, nauki i rozrywki.

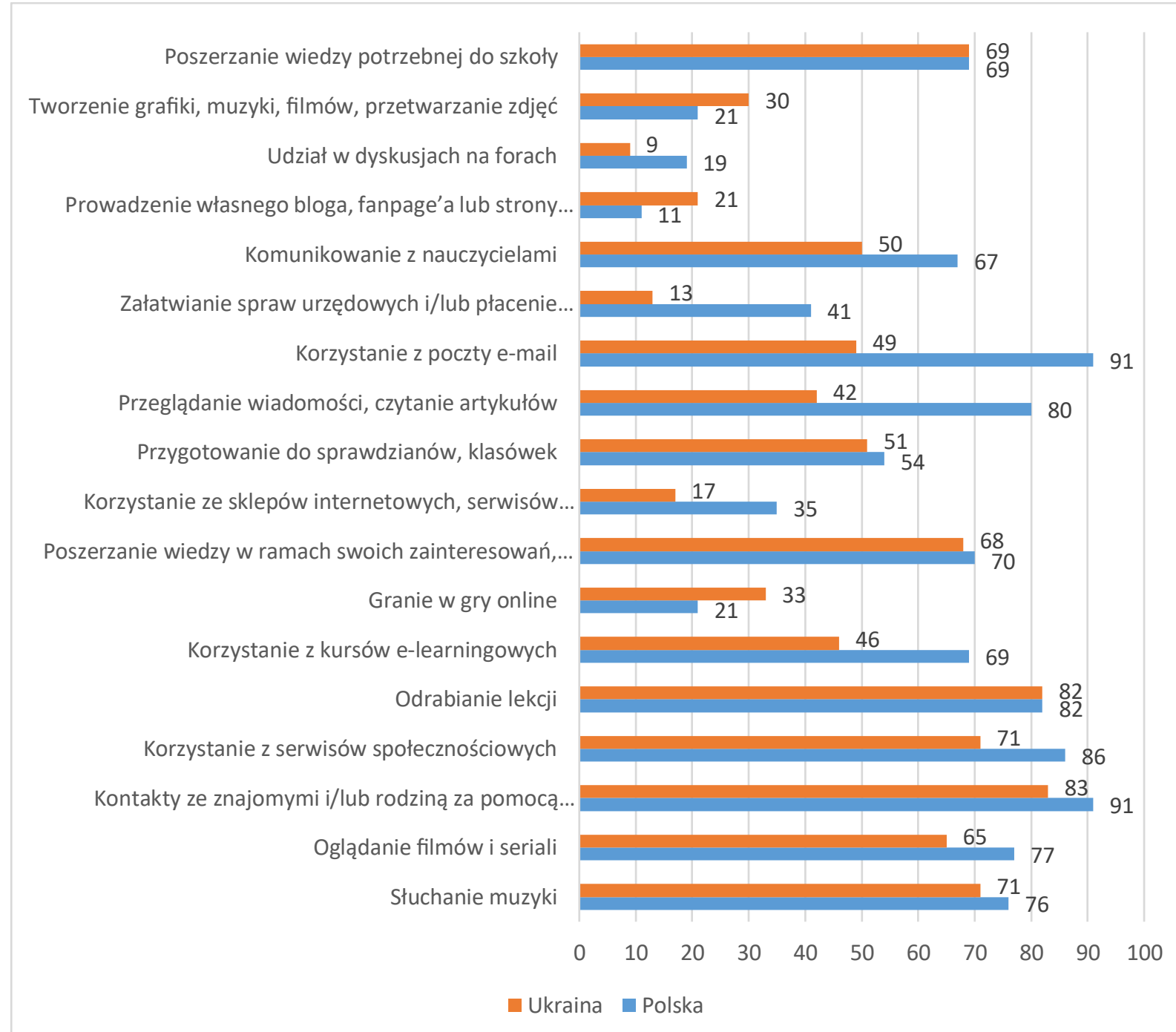

Wykres 19. Typy aktywności w sieci (\%) 
Porównanie wyników między polskimi i ukraińskimi uczniami pokazuje, że struktura korzystania $\mathrm{z}$ internetu jest podobna. Jednakże w kilku przypadkach zaobserwowano duże różnice między obiema grupami. Polscy uczniowie częściej korzystają w internecie z kursów e-learningowych (różnica 23 punktów procentowych), robią zakupy w sklepach internetowych (różnica 18 punktów procentowych), przeglądają informacje i wiadomości (różnica 38 punktów procentowych), korzystają z poczty elektronicznej (różnica 42 punktów procentowych) i załatwiają sprawy urzędowe (różnica 28 punktów procentowych). Młodzież ukraińska częściej deklarowała, że tworzy grafikę, muzykę (różnica 9 punktów procentowych), własne blogi (różnica 10 punktów procentowych) oraz gra w gry online (różnica 11 punktów procentowych).

Pojawiające się różnice między obiema grupami młodzieży wskazują, że polska młodzież częściej wykorzystuje internet do funkcjonowania w sferze publicznej, a ukraińska jest nieco częściej aktywnym uczestnikiem cyfrowej rzeczywistości, w której stara się pełnić rolę nie tylko biernego odbiorcy, ale też aktywnego twórcy w cyfrowym świecie.

Analiza czynnikowa pozwala na przygotowanie dokładnej typologii aktywności młodzieży $\mathrm{w}$ internecie. Za jej pomocą można zestawić działania, które łączą się ze sobą, tworząc syndromy aktywności. Ponadto analiza czynnikowa pozwala zredukować dziewiętnaście różnych aktywności do pięciu głównych, dzięki czemu łatwiej jest prowadzić analizy (tabela 3 patrz s. 24).
W przypadku polskiej młodzieży pierwszy czynnik jest tworzony przez aktywność związaną $\mathrm{z}$ edukacją szkolną. W jego zakres wchodzi odrabianie lekcji, korzystanie z kursów e-learningowych, przygotowanie się do sprawdzianów, klasówek, korzystanie z poczty e-mail, komunikowanie się z nauczycielami oraz poszerzanie wiedzy potrzebnej w procesie edukacji. Można skonstatować, że działania te są podporządkowane zdalnej edukacji. Internet jest więc tu wykorzystywany w celu prowadzenia edukacji szkolnej.

Drugi czynnik obejmuje tylko dwie praktyki, którymi są: poszerzanie wiedzy w ramach swoich zainteresowań oraz czytanie czasopism czy komiksów. Działania te można zaliczyć do hobbystycznej aktywności w internecie.

Trzeci czynnik składa się z praktyk takich jak granie w gry online, prowadzenie własnego bloga, udział w dyskusjach na forach oraz tworzenie własnych grafik, filmików. Wszystkie te działania można nazwać aktywnym wykorzystywaniem internetu.

Kolejny czynnik mieści w sobie takie działania jak słuchanie muzyki, oglądanie filmów, kontakty ze znajomymi za pomocą komunikatorów czy korzystanie z serwisów społecznościowych. Wymienione praktyki są powszechne wśród użytkowników sieci. Przeciętny uczeń do tych celów w dużej mierze wykorzystuje właśnie internet.

Ostatni czynnik obejmuje takie aktywności $\mathrm{w}$ internecie jak zakupy, przeglądanie artykułów, załatwianie spraw urzędowych. Działania te można zaliczyć do uczestnictwa w sferze publicznej. Młodzież wykorzystuje internet do podejmowania aktywności obywatelskich. 
Tabela 3. Wyniki analizy czynnikowej dla sposobów spędzania czasu w internecie (Polska)

\begin{tabular}{|c|c|c|c|c|c|}
\hline & \multicolumn{5}{|c|}{ Czynnik } \\
\hline & Edukacyjny & Hobbystyczny & Twórczy & Komunikacyjny & Obywatelski \\
\hline Słuchanie muzyki & & & & 0,505 & \\
\hline Oglądanie filmów i seriali & & & & 0,520 & \\
\hline $\begin{array}{l}\text { Kontakty ze znajomymi i/lub rodziną za pomocą } \\
\text { komunikatorów, czatów }\end{array}$ & & & & 0,703 & \\
\hline Korzystanie z serwisów społecznościowych & & & & 0,757 & \\
\hline Odrabianie lekcji & 0,783 & & & & \\
\hline Korzystanie z kursów e-learningowych & 0,483 & & & & \\
\hline Granie w gry online & & & 0,278 & & \\
\hline $\begin{array}{l}\text { Poszerzanie wiedzy w ramach swoich zainteresowań, } \\
\text { hobby }\end{array}$ & & 0,951 & & & \\
\hline Czytanie czasopism, komiksów & & 0,951 & & & \\
\hline $\begin{array}{l}\text { Korzystanie ze sklepów internetowych, serwisów } \\
\text { aukcyjnych }\end{array}$ & & & & & 0,688 \\
\hline Przygotowywanie się do sprawdzianów, klasówek & 0,762 & & & & \\
\hline Przeglądanie wiadomości, czytanie artykułów & & & & & 0,457 \\
\hline Korzystanie z poczty e-mail & 0,578 & & & & \\
\hline $\begin{array}{l}\text { Załatwianie spraw urzędowych i/lub płacenie rachun- } \\
\text { ków itp. }\end{array}$ & & & & & 0,704 \\
\hline Komunikacja z nauczycielami & 0,754 & & & & \\
\hline $\begin{array}{l}\text { Prowadzenie własnego bloga, fanpagéa lub strony } \\
\text { internetowej }\end{array}$ & & & 0,787 & & \\
\hline $\begin{array}{l}\text { Przeglądanie i/lub branie udziału w dyskusjach na } \\
\text { forach }\end{array}$ & & & 0,645 & & \\
\hline $\begin{array}{l}\text { Tworzenie grafiki, muzyki, filmów, przetwarzanie } \\
\text { zdjęć }\end{array}$ & & & 0,755 & & \\
\hline Poszerzanie wiedzy potrzebnej do szkoły & 0,763 & & & & \\
\hline
\end{tabular}

W wyniku analizy czynnikowej udało się wyróżnić pięć typów zachowań w internecie. Kolejnym krokiem analiz będzie sprawdzenie, w jaki sposób zmienne niezależne wpływają na te wyodrębnione praktyki. W tym celu przeprowadzono analizę korelacyjną i jej wyniki zostały przedstawione poniżej w tabeli 4 (patrz s. 25).

Wykorzystywanie w czasie kwarantanny internetu do celów edukacyjnych widoczne jest u uczniów bardziej zainteresowanych pandemią, mających wiedzę o liczbie zarażonych oraz obawiających się zarażenia. Uczniowie ci są bardziej religijni, mieszkają poza Krakowem i mają lepsze stopnie szkolne. Częściej są to dziewczęta.
Analiza pokazuje też, że styl edukacyjny jest skorelowany z mobilizowaniem się wobec zagrożenia koronawirusem i z nawykiem modlenia się do Boga o pomoc oraz ujemnie skorelowany z zażywaniem środków psychoaktywnych.

Hobbystyczne wykorzystanie internetu w czasie kwarantanny częściej obserwuje się u licealistów płci męskiej, których rodzice są lepiej wykształceni. Ci uczniowie są też lepiej wyposażeni w sprzęt AGD oraz nie starają się stosować strategii „słodkiej cytryny” w obliczu pandemii.

Aktywnymi użytkownikami internetu, czyli tymi, którzy starają się coś stworzyć w cyfrowej rzeczywistości, są przede wszystkim chłop- 
Tabela 4. Korelaty dla rodzajów spędzania wolnego czasu w internecie (Polska)

\begin{tabular}{|c|c|c|c|c|c|}
\hline & Edukacyjny & Hobbystyczny & Twórczy & Komunikacyjny & Obywatelski \\
\hline Poziom zainteresowania pandemią & 0,138 & & & & 0,106 \\
\hline Poczucie zagrożenia koronawirusem & 0,126 & & & & \\
\hline Religijność & 0,169 & & & & \\
\hline Miejsce zamieszkania & 0,108 & & & & \\
\hline Oceny szkolne & 0,201 & & & 0,102 & \\
\hline Płeć & 0,266 & 0,297 & 0,140 & 0,132 & \\
\hline Wiek & & & & & 0,173 \\
\hline Typ szkoły & & 0,136 & & & \\
\hline Wykształcenie matki & & 0,146 & & & \\
\hline Wykształcenie ojca & & 0,143 & & & \\
\hline Indeks AGD & & 0,105 & & & \\
\hline Czas spędzany w internecie & & & & 0,263 & \\
\hline Wiedza o liczbie zarażonych & 0,106 & & & & \\
\hline Obawa przed zarażeniem & 0,196 & & & & \\
\hline Zwracanie się o radę i pomoc do innych & 0,154 & & & & \\
\hline Mobilizacja wobec zagrożenia & 0,166 & & & & \\
\hline Sięganie po alkohol, papierosy & $-0,159$ & & & 0,109 & 0,131 \\
\hline Modlenie się do Boga & 0,173 & & & $-0,139$ & \\
\hline Pocieszanie się, że mogło być gorzej & & $-0,103$ & & 0,101 & \\
\hline Zażywanie środków uspokajających & & & 0,110 & & 0,101 \\
\hline
\end{tabular}

cy. Częściej są to też osoby stosujące środki uspokajające.

Do celów komunikacyjnych w trakcie kwarantanny internet częściej wykorzystują dziewczęta, częściej też ci uczniowie mają gorsze stopnie szkolne i więcej czasu spędzają dziennie w sieci. Ponadto częściej preferują zażywanie środków psychoaktywnych oraz w obliczu pandemii częściej stosują pocieszanie się, że mogło być gorzej. Raczej nie odwołują się do boskiej opatrzności.

Wykorzystywanie internetu w celu załatwiania różnych spraw, np. robienia zakupów, jest częstsze wśród starszych uczniów, którzy są zainteresowani pandemią. Sięgają też oni częściej po alkohol i środki psychoaktywne oraz pomagają sobie, zażywając środki uspokajające.

Wśród ukraińskiej młodzieży za pomocą analizy czynnikowej również wyspecyfikowa- no pięć typów zachowań w internecie w czasie kwarantanny (tabela 5 - patrz s. 26).

Pierwszy czynnik jest tworzony przez aktywność związaną z edukacją szkolną. W jego zakres wchodzi odrabianie lekcji, korzystanie z kursów e-learningowych, poszerzanie wiedzy w ramach swoich zainteresowań, przygotowanie się do sprawdzianów, klasówek, przeglądanie wiadomości, czytanie artykułów, korzystanie z poczty e-mail, komunikowanie się z nauczycielami oraz poszerzanie wiedzy wymaganej na zajęciach w szkole. Można uznać, że wszystkie te praktyki są podporządkowane zdalnej edukacji.

Drugi czynnik można nazwać twórczym. Składa się nań prowadzenie własnego bloga, udział $w$ dyskusjach na forach oraz tworzenie własnych grafik, filmików. Wszystkie te działania można nazwać aktywnym wykorzystywaniem internetu. 
Tabela 5. Wyniki analizy czynnikowej dla sposobów spędzania czasu w internecie (Ukraina)

\begin{tabular}{|c|c|c|c|c|c|}
\hline & \multicolumn{5}{|c|}{ Czynnik } \\
\hline & Edukacyjny & Twórczy & Komunikacyjny & Obywatelski & Hobbystyczny \\
\hline Słuchanie muzyki & & & 0,553 & & \\
\hline Oglądanie filmów i seriali & & & 0,604 & & \\
\hline $\begin{array}{l}\text { Kontakty ze znajomymi i/lub rodziną za pomocą } \\
\text { komunikatorów, czatów }\end{array}$ & & & 0,634 & & \\
\hline Korzystanie z serwisów społecznościowych & & & 0,681 & & \\
\hline Odrabianie lekcji & 0,690 & & & & \\
\hline Korzystanie z kursów e-learningowych & 0,609 & & & & \\
\hline Granie w gry online & & & & & 0,804 \\
\hline $\begin{array}{l}\text { Poszerzanie wiedzy w ramach swoich } \\
\text { zainteresowań, hobby }\end{array}$ & 0,403 & & & & \\
\hline $\begin{array}{l}\text { Korzystanie ze sklepów internetowych, serwisów } \\
\text { aukcyjnych }\end{array}$ & & & & 0,735 & \\
\hline Przygotowywanie się do sprawdzianów, klasówek & 0,723 & & & & \\
\hline Przeglądanie wiadomości, czytania artykułów & 0,442 & & & & \\
\hline Korzystanie z poczty e-mail & 0,542 & & & & \\
\hline $\begin{array}{l}\text { Załatwianie spraw urzędowych i/lub płacenie } \\
\text { rachunków itp. }\end{array}$ & & & & 0,758 & \\
\hline Komunikacja z nauczycielami & 0,677 & & & & \\
\hline $\begin{array}{l}\text { Prowadzenie własnego bloga, fanpage’a lub } \\
\text { strony internetowej }\end{array}$ & & 0,742 & & & \\
\hline Przeglądanie i/lub udział w dyskusjach na forach & & 0,541 & & & \\
\hline $\begin{array}{l}\text { Tworzenie grafiki, muzyki, filmów, przetwarzania } \\
\text { zdjęć }\end{array}$ & & 0,781 & & & \\
\hline Poszerzanie wiedzy potrzebnej do szkoły & 0,750 & & & & \\
\hline
\end{tabular}

Trzeci czynnik skupia w sobie takie działania jak słuchanie muzyki, oglądanie filmów, kontakty ze znajomymi za pomocą komunikatorów i korzystanie z serwisów społecznościowych. Praktyki te są powszechne dla użytkowników sieci; przeciętny uczeń do tych celów w dużej mierze wykorzystuje właśnie internet.

Czwarty czynnik obejmuje takie czynności $w$ internecie jak zakupy internetowe oraz załatwianie spraw urzędowych. Działania te można zaliczyć do uczestnictwa w sferze publicznej i możliwość prowadzenia konsumpcji online.

Ostatni czynnik w swoim zasięgiem obejmuje uczestnictwo w grach online i można zaliczyć go do praktyk hobbystycznych.
W kolejnym kroku analiz, analogicznie jak w przypadku danych z Polski, starano się zbadać, w jaki sposób cyfrowe praktyki z czasów kwarantanny są powiązane $\mathrm{z}$ różnymi zmiennymi niezależnymi (tabela 6 - patrz s. 27).

Uczniowie preferujący edukacyjny styl w cyfrowej rzeczywistości wykazują zainteresowanie zjawiskiem pandemii, uważają ją także za poważny problem, który zagraża życiu i zdrowiu obywateli Ukrainy, jak też im samym. Ci uczniowie częściej uczestniczą w wolontariatach, są bardziej religijni, mają lepsze stopnie szkolne oraz mniej czasu spędzają w internecie. Wśród tych uczniów pojawia się tendencja do sięgania po alkohol i środki psychoaktywne, częściej zaś 
Tabela 6. Korelaty dla rodzajów spędzania wolnego czasu w internecie (Ukraina)

\begin{tabular}{|c|c|c|c|c|c|}
\hline & Edukacyjny & Twórczy & Komunikacyjny & Obywatelski & Hobbystyczny \\
\hline Poziom zainteresowania pandemią & 0,268 & & & & \\
\hline Poczucie zagrożenia koronawirusem & 0,144 & & & & \\
\hline $\begin{array}{l}\text { Koronawirus zagrożeniem dla } \\
\text { Ukraińców }\end{array}$ & 0,101 & & & & \\
\hline Religijność & 0,153 & & & & \\
\hline \multicolumn{6}{|l|}{ Miejsce zamieszkania } \\
\hline Oceny szkolne & 0,143 & & & & \\
\hline Płeć & & 0,102 & 0,151 & & 0,519 \\
\hline \multicolumn{6}{|l|}{ Wiek } \\
\hline \multicolumn{6}{|l|}{ Typ szkoły } \\
\hline Zadowolenie z życia & & & & & 0,174 \\
\hline \multicolumn{6}{|l|}{ Wykształcenie matki } \\
\hline \multicolumn{6}{|l|}{ Wykształcenie ojca } \\
\hline Indeks AGD & & & 0,137 & & \\
\hline Czas spędzany w internecie & $-0,161$ & & 0,243 & & \\
\hline Wiedza o liczbie zarażonych & 0,144 & & & & \\
\hline Obawa przed zarażeniem & 0,200 & & & & \\
\hline \multicolumn{6}{|l|}{$\begin{array}{l}\text { Zwracanie się o radę i pomoc do } \\
\text { innych }\end{array}$} \\
\hline Mobilizacja wobec zagrożenia & $-0,219$ & & & & \\
\hline Sięganie po alkohol, papierosy & 0,181 & & & 0,114 & \\
\hline Modlenie się do Boga & $-0,164$ & & & & \\
\hline \multicolumn{6}{|l|}{ Pocieszanie się, że mogło być gorzej } \\
\hline \multicolumn{6}{|l|}{ Zażywanie środków uspokajających } \\
\hline $\begin{array}{l}\text { Zajmowanie się rzeczami, które } \\
\text { odwracają uwagę }\end{array}$ & $-0,137$ & & & & \\
\hline Pomoc starszym & 0,126 & & & 0,150 & \\
\hline
\end{tabular}

odrzucają pozostałe metody radzenia sobie ze stresem.

Przejawy twórczej działalności w internecie są skorelowane tylko z płcią. Częściej pojawiają się wśród uczennic.

Komunikacyjny styl korzystania $\mathrm{z}$ internetu w czasie kwarantanny jest widoczny częściej $\mathrm{u}$ dziewcząt zasobniejszych materialnie. Ta grupa młodzieży spędza też więcej czasu w internecie.

Typ obywatelski korzystania $z$ internetu charakterystyczny jest częściej dla uczniów pomagających starszym osobom $\mathrm{w}$ robieniu zakupów oraz mających awersję do sięgania w czasie kwarantanny po alkohol.

Ostatni czynnik jest mocno powiązany z płcią. W gry online są głównie zaangażowani chłopcy, którzy nie są zadowoleni z życia.

Wiemy, że badana młodzież należy do tzw. i-generacji, czyli pokolenia internetu [Twenge 2019], w związku z tym wprowadzenie kwarantanny nie zmieniło radykalnie ich trybu życia, gdyż już przed wybuchem pandemii młodzież była w znacznym stopniu zaznajomiona $\mathrm{z}$ rzeczywistością cyfrową. 


\section{9. Życie poza siecią}

zęsto zwraca się uwagę, że cyfrowy styl życia wywołuje u młodych ludzi swego rodzaju „niestrawność” $\mathrm{z}$ powodu nadmiaru dostarczanych im informacji. Zdalna edukacja jeszcze wzmocniła zjawisko tego cyfrowego przeciążenia. W związku z powyższym młodzież może też dążyć do ucieczki od cyfrowej rzeczywistości.

Na wykresie 20 widać, że w przypadku obu grup młodzieży uczniowie w tym, można by rzec, wymuszonym wolnym czasie najczęściej słuchają muzyki. Nieco rzadziej spędzają go na oglądaniu telewizji i filmów na płytach DVD, czytaniu książek i leniuchowaniu.

Młodzi ludzie nie tylko przebywają w domu, ale również wychodzą na zewnątrz i spacerują po okolicy oraz uprawiają sport. Grają także w różne gry na komputerze. Spotykają się z rodzinami, swoimi dziewczynami/chłopakami oraz przyjaciółmi. Najrzadziej zaś czytają komiksy i kolorową prasę.

Należy zauważyć, że badani uczniowie stosują się do zaleceń i ograniczają swój kontakt

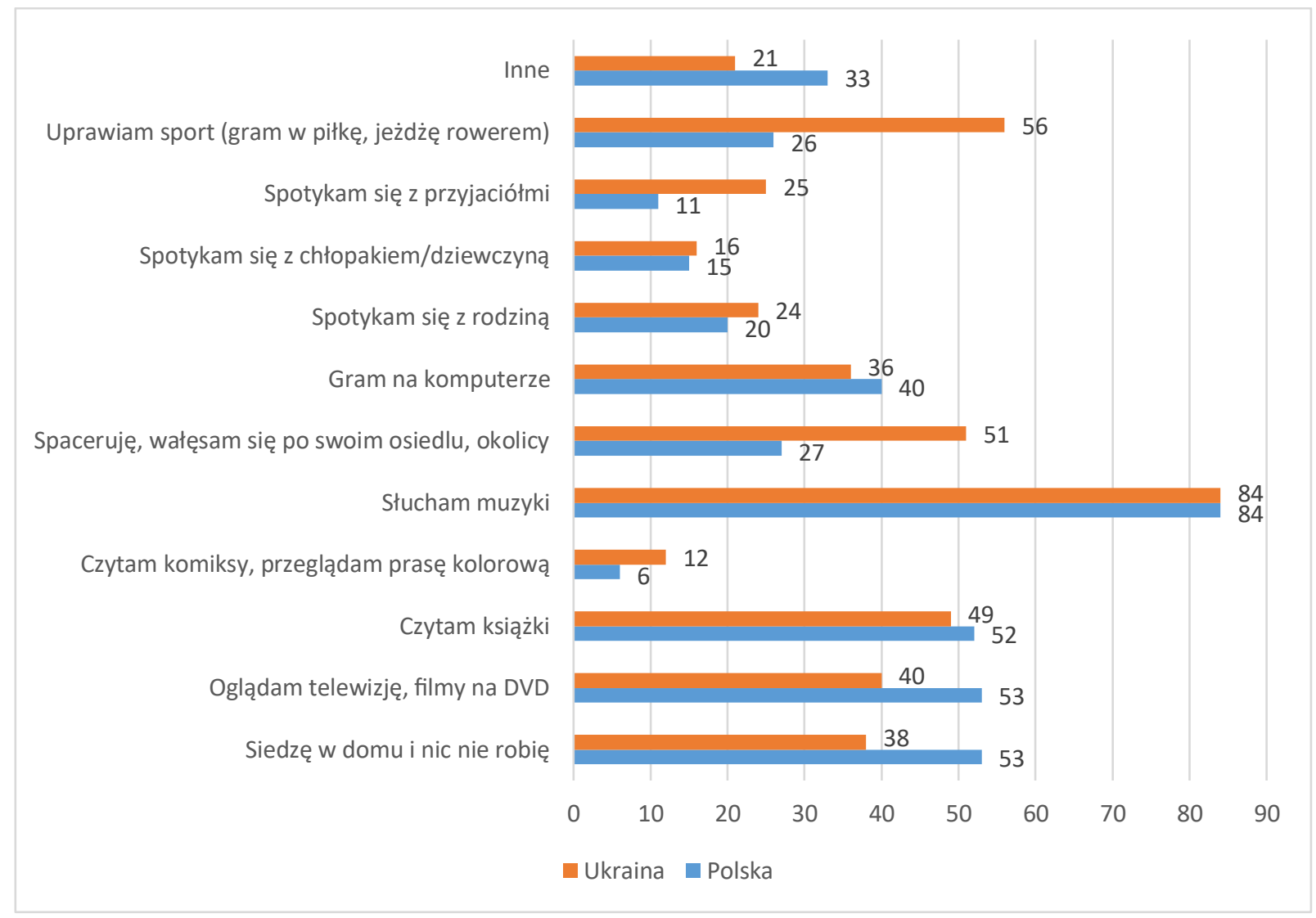

Wykres 20. W jaki sposób poza korzystaniem z internetu spędzasz jeszcze swój czas? (\%) 
$\mathrm{z}$ innymi. W niewielkim stopniu wykorzystują przerwę od zajęć w szkole do kontaktów społecznych.

Warto też zaznaczyć, że w kilku aktywnościach w trakcie spędzania czasu wolnego przez uczniów w obu krajach widoczne są różnice. Polska młodzież częściej spędza swój czas w sposób bierny, oglądając telewizję lub nic nie robiąc. Ukraińska młodzież wykazuje zaś większą aktywność pod względem uprawiania sportu, spacerowania po okolicy i spotykania się z przyjaciółmi.

Być może zaobserwowane rozbieżności wynikają $\mathrm{z}$ różnych okresów prowadzenia badań, w których to ostrzejsze restrykcje obowiązywały w Polsce niż na Ukrainie. Jednakże różnice te mogą także wynikać $\mathrm{z}$ różnic kulturowych między Polską a Ukrainą. Zamiłowanie do aktywności fizycznej i kultury fizycznej jest bardziej widoczne na Ukrainie. Sport jest tam metodą wychowywania młodzieży, sposobem na kształtowanie jej charakteru. Być może jest też tak, że młodzi Ukraińcy nie są jeszcze w tak znacznym stopniu pochłonięci kulturą internetową i przedkładają rzeczywiste spotkania nad kontakty w rzeczywistości wirtualnej.

Tabela 7 pokazuje, że niektóre formy aktywności są zróżnicowane także ze względu na płeć. Dziewczęta w obu państwach częściej niż mężczyźni oglądają telewizję i filmy, czytają książki i słuchają muzyki.

Chłopcy zaś zdecydowanie częściej niż dziewczęta grają w czasie kwarantanny w gry komputerowe. Interesujące jest też to, że w obu grupach to dziewczęta częściej zaznaczały, że w tym czasie spotykają się ze swoimi sympatiami.

Tabela 7. Aktywność młodzieży w czasie wolnym a płeć (\%)

\begin{tabular}{|l|c|c|c|c|}
\hline \multirow{2}{*}{} & \multicolumn{2}{c}{ Polska } & Kobieta & Mężczyzna \\
\hline Siedzę w domu i nic nie robię & Kobieta & Męizczyzna & 39 & 36 \\
\hline Oglądam telewizję, filmy na DVD & 55 & 51 & 43 & 39 \\
\hline Czytam książki & 60 & 42 & 56 & 40 \\
\hline Czytam komiksy, przeglądam prasę kolorową & 56 & 45 & 13 & 12 \\
\hline Słucham muzyki & 6 & 6 & 88 & 80 \\
\hline Spaceruję, wałęsam się po swoim osiedlu, okolicy & 86 & 81 & 52 & 51 \\
\hline Gram na komputerze & 30 & 22 & 17 & 67 \\
\hline Spotykam się z rodziną & 22 & 71 & 22 & 27 \\
\hline Spotykam się z chłopakiem/dziewczyną & 19 & 23 & 21 & 10 \\
\hline Spotykam się z przyjaciółmi & 16 & 13 & 20 & 26 \\
\hline Uprawiam sport (gram w piłkę, jeżdżę rowerem) & 11 & 12 & 58 & 55 \\
\hline Inne & 25 & 27 & 21 & 20 \\
\hline
\end{tabular}




\section{Pomaganie seniorom}

olejną kwestią rozważaną $\mathrm{w}$ analizie społecznych praktyk w czasie pandemii jest zaangażowanie młodych ludzi w akcje niesienia pomocy seniorom. Akcje te są propagowane i wspierane przez media, w związku z tym w ankiecie zapytano, czy uczniowie włączyli się w działalność mającą na celu pomoc i ochronę seniorów przed zarażeniem wirusem.

Z obserwacji przedstawionych na wykresie 21 wynika, że niewielka część badanych uczniów była zaangażowana w pomoc seniorom. Pomoc ta polega na robieniu zakupów oraz załatwianiu spraw urzędowych bądź związanych ze zdrowiem. W Polsce tylko co piąty uczeń zadeklarował, że uczestniczy w takich akcjach, a na Ukrainie co trzeci uczeń.

Zarówno w Polsce, jak i na Ukrainie swój udział akcji na rzecz niesienia pomocy starszym osobom częściej deklarowali uczniowie bardziej religijni. Oznacza to, że wyznawanie wartości związanych z religią zwiększa poziom zaangażowania młodzieży w działania na rzecz innych osób.

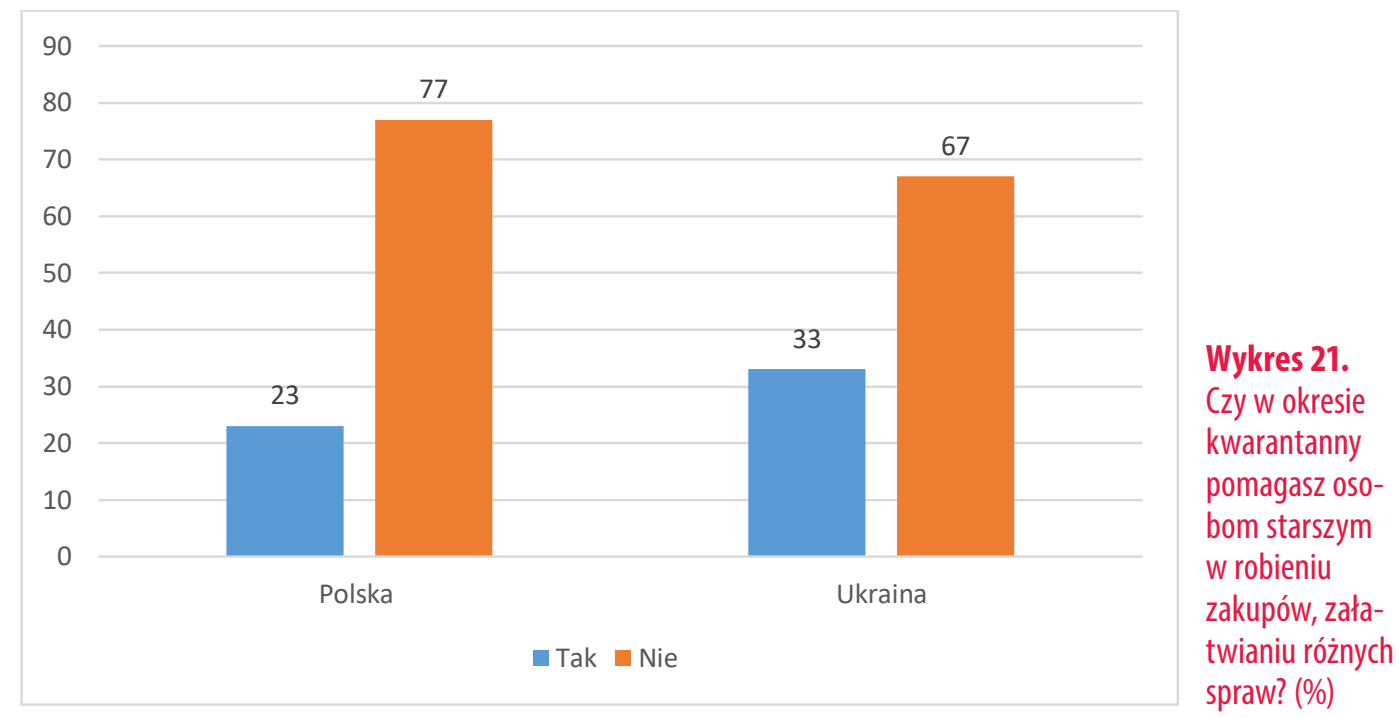




\section{Młodzież w edukacji zdalnej}

7 awieszenie zajęć w szkołach wymusiło podejmowanie działań pozwalających na kontynuację edukacji w formie zdalnej. $Z$ dnia na dzień władze szkolne, nauczyciele, rodzice, a przede wszystkim sami uczniowie zostali postawieni przed nowym wyzwaniem. Wszystkim sytuacja ta stwarzała pewne problemy, począwszy od technicznych, związanych z dostępem do szerokopasmowego internetu i odpowiedniego sprzętu, poprzez te związane z kompetencjami cyfrowymi, informatycznymi, aż do dydaktycznych, polegających na dostosowaniu form zajęć do nowych narzędzi przekazu oraz do umiejętności uczniów. Szczególnie młodsze dzieci mają trudności z przestawieniem się na nauczanie zdalne i bez pomocy rodziców trudno jest im uzyskać dostęp do lekcji online. Pojawia się też kwestia dostosowania się do formy cyfrowego przekazu, co wymaga od uczniów samodyscypliny, koncentracji, pilności i samodzielności.

Niewątpliwie jest to nowe zjawisko, które będzie miało swoje skutki w wymiarze społecznym oraz psychologicznym. Aby się przekonać, jak oceniane są lekcje zdalne, zadano pytanie dotyczące tego, czy uczniowie uczestniczyli w lekcjach online. Dane na wykresie 22 pokazują, że w grupie polskiej młodzieży $68 \%$ badanych uczestniczyło w nich, a na Ukrainie poziom uczestnictwa w lekcjach online był wyższy i wynosił $83 \%$. Warto dodać, że badania wśród polskiej młodzieży były realizowane na samym początku kwarantanny, co też mogło spowodować różnice w wynikach. $\mathrm{Na}$ Ukrainie były one przeprowadzone później, kiedy już szkoły wprowadzały zdalne nauczanie.

Zapytano także uczniów, co sądzą o wpływie zdalnej edukacji na ich poziom wiedzy. $Z$ rozkładu odpowiedzi (wykres 23 - patrz s. 32) wyni$\mathrm{ka}, \dot{z ̇ e}$ uczniowie negatywnie wypowiadają się na temat skuteczności zdalnej edukacji. Lekcje online nie cieszą się ich uznaniem. Tylko około co piąty ankietowany uważa, że zdalne nauczanie może zastąpić nauczanie tradycyjne. W obu krajach młodzież zajmuje podobne stanowisko.

Analizy wskazują jednak, że lepiej oceniają lekcje online ci uczniowie, którzy uczestniczyli w takich lekcjach niż uczniowie nieuczestniczący w zdalnym nauczaniu.

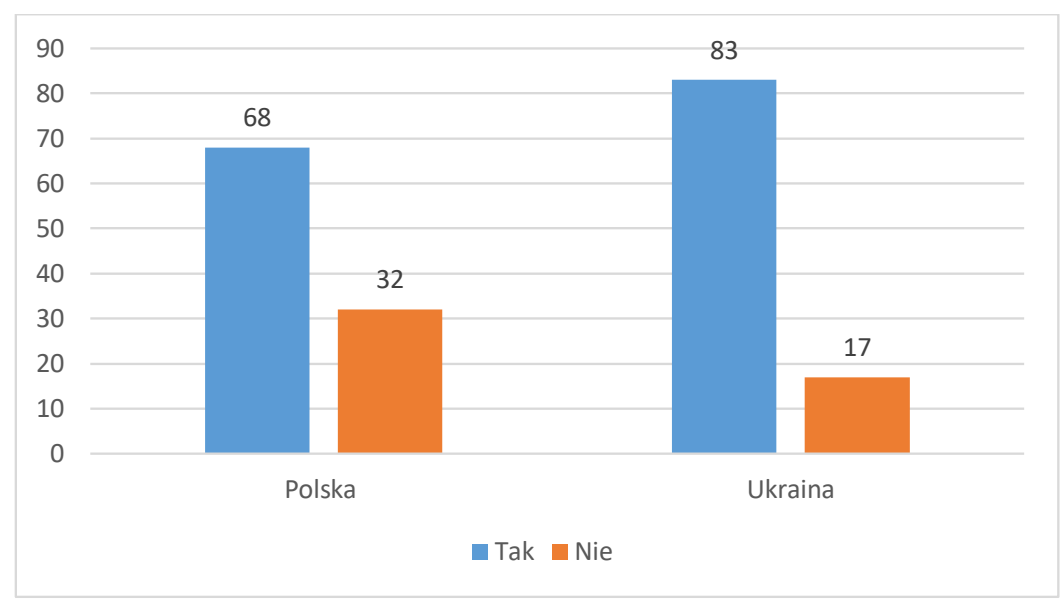

Wykres 22. Czy uczestniczyłeś w zajęciach online prowadzonych przez nauczycieli z Twojej szkoły? (\%) 


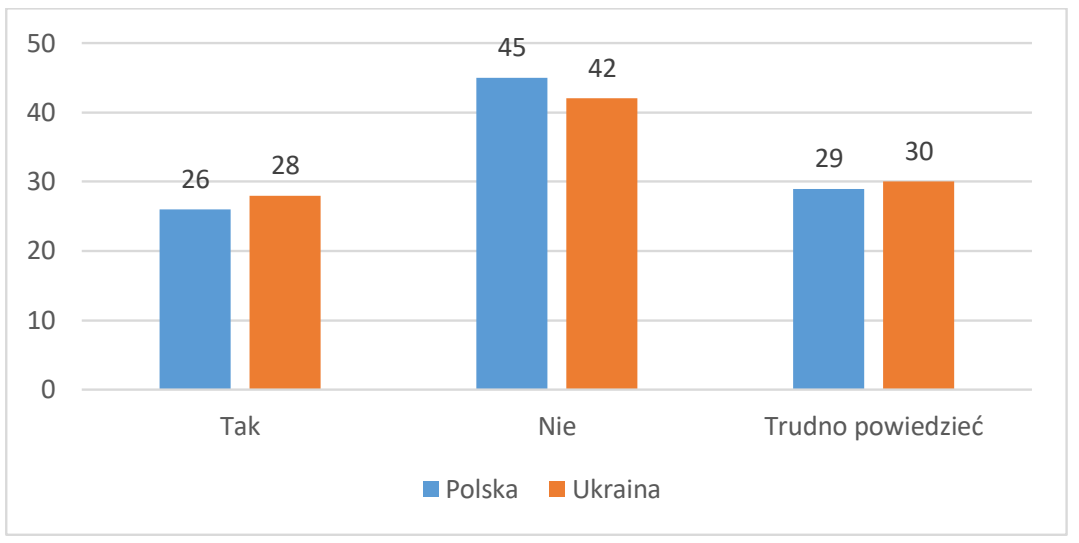

Wykres 23. Czy

uważasz, że zajęcia online są tak samo pomocne w zdobywaniu wiedzy z zakresu przedmiotów szkolnych jak tradycyjne lekcje? (\%)
Ostatnią kwestią poruszoną w ankiecie była ocena wpływu pandemii koronawirusa na perspektywy życiowe młodzieży. Sytuacja przedłużającej się kwarantanny może mieć bowiem także swoje długofalowe konsekwencje. Brak zajęć może skutkować niższym poziomem wiedzy szkolnej. Zajęcia online również nie sa w stanie całkowicie zastąpić tradycyjnej formy przekazu.

Kwarantanna pozbawiła ponadto uczniów możliwości korzystania z zajęć dodatkowych, sportowych, artystycznych czy korepetycji. Trudno jest też przewidywać, jak zdalne nauczanie wpłynie na poziom wiedzy uczniów mierzony na egzaminie maturalnym. Jeszcze trudniej jest określić, jak pandemia i towarzyszące jej zjawiska, np. kryzys ekonomiczny, wpłyną na rynek pracy, szanse rozwoju kariery, dobrostanu.

Dane prezentowane w tabeli 9 pokazują spodziewany wpływ zawieszenia zajęć w szkołach na różne obszary życia uczniów. $Z$ analiz wynika, że młodzież w obu krajach najczęściej jest przekonana, że przerwa w szkolnych zajęciach nie będzie miała wpływu na ich życie.

Jeśli uwzględnimy negatywne skutki pandemii, to w Polsce uczniowie częściej podkreślali, że kwarantanna może wpłynąć na obniżenie poziomu wiedzy szkolnej oraz pogorszyć wyniki egzaminów maturalnych.

Na Ukrainie zaś młodzież częściej obawia się negatywnego wpływu zdalnego nauczania na poziom wiedzy szkolnej i szanse dostania się na dobre studia. W mniejszym stopniu uczniowie przewidują, że na skutek pandemii będą mieć problem $\mathrm{z}$ odniesieniem sukcesu zawodowego oraz realizacją obranej kariery życiowej.

Warto zauważyć, że młodzież, mówiąc o pozytywach tej sytuacji, wskazuje na możliwość zwiększenia zadowolenia z życia. Jest to szczególnie widoczne wśród ukraińskiej młodzieży. Być może część młodzieży postrzega zawieszenie zajęć jako zwolnienie od szkolnego obowiązku i związanych z nim uciążliwości, co w konsekwencji mogłoby poprawić dobrostan psychologiczny uczniów.

Tabela 9. Jaki wpływ na poniższe aspekty Twojego życia może mieć zawieszenie zajęć w szkołach? (\%)

\begin{tabular}{|c|c|c|c|c|c|c|}
\hline & \multicolumn{3}{|c|}{ Polska } & \multicolumn{3}{|c|}{ Ukraina } \\
\hline & Pozytywny & Bez znaczenia & Negatywny & Pozytywny & Bez znaczenia & Negatywny \\
\hline Poziom szkolnej wiedzy & 19 & 40 & 41 & 19 & 43 & 38 \\
\hline Wyniki na egzaminie maturalnym & 14 & 48 & 38 & 24 & 45 & 31 \\
\hline Szanse przyjęcia na dobre studia & 13 & 55 & 32 & 19 & 46 & 35 \\
\hline Kariera życiowa & 16 & 58 & 26 & 26 & 51 & 23 \\
\hline Sukces zawodowy & 16 & 59 & 25 & 23 & 49 & 28 \\
\hline Zadowolenie z życia & 31 & 35 & 34 & 48 & 31 & 21 \\
\hline
\end{tabular}




\section{Zakończenie}

adania i przedstawione analizy wyników dają wgląd w sytuację młodzieży szkolnej na początku kwarantanny w Polsce i na Ukrainie. Dzięki badaniom sondażowym wiadomo, w jaki sposób młodzież radziła sobie $\mathrm{z}$ tą niecodzienną i trudną sytuacją, jaką było zamknięcie szkół i gospodarki:

- Przeprowadzone badania pokazują, że młodzież interesuje się pandemią i śledzi doniesienia na jej temat. Ma też wiedzę na temat liczby zakażonych w danym czasie, przy czym zainteresowanie pandemią jest większe wśród polskiej młodzieży niż ukraińskiej.

- Większość badanych uważa, że koronawirus stanowi poważne zagrożenie dla zdrowia i życia obywateli. W mniejszym stopniu uczniowie deklarowali, że zagrożenie koronawirusem może dotyczyć ich bezpośrednio. Także i w tym przypadku polscy uczniowie mniej się boją zarażenia niż ukraińscy.

- W obu krajach prawdopodobieństwo indywidualnego zarażenia się szacowane jest na $30 \%$. Osobisty lęk przed koronawirusem nie jest zatem wysoki.

- Ocena działań władz odpowiedzialnych za walkę z koronawirusem jest odmienna w zależności od kraju. Wśród polskich uczniów przeważają pozytywne oceny służb odpowiedzialnych za ochronę ludności, wśród ukraińskich - oceny negatywne.

- Większość młodzieży w obu krajach jest zadowolona z życia, przy czym wyższy poziom dobrostanu psychologicznego wykazuje młodzież ukraińska.

- Młodzi ludzie w celu radzenia sobie z sytuacją pandemii najczęściej starają się odwracać swoją uwagę od zagrożenia, a także mobilizują się i walczą z zagrożeniem poprzez stosowanie się do zasad bezpieczeństwa, nieco rzadziej zaś pocieszają się, że nie jest tak źle, gdyż sytuacja mogłaby być gorsza.

- Większość czasu kwarantanny młodzież spędza w internecie. W cyfrowej rzeczywistości uczniowie wykonują swoje obowiązki związane ze zdalną nauką. Sieć jest też wykorzystywana do komunikacji oraz rozrywki.

- Uczniowie spędzają też czas wolny poza siecią. Najczęściej słuchają muzyki, uprawiają sport lub siedzą w domu. Uczniowie ukraińscy częściej uprawiają sport i spacerują po okolicy. Polscy uczniowie częściej preferują bierne spędzanie czasu.

- Relatywnie niewielka część badanej młodzieży angażuje się w pomoc seniorom. Częściej taką aktywność widać u młodzieży ukraińskiej niż polskiej.

- Większość młodzieży uczestniczyła w lekcjach online, przy czym na Ukrainie udział ten był wyższy niż w Polsce.

- Ocena zajęć online wypada negatywnie. W obu krajach większość badanych uważa, że takie zajęcia nie są w stanie zastąpić tradycyjnych lekcji. Uczniowie twierdzą, że edukacja zdalna może wpłynąć na obniżenie wiedzy szkolnej, choć na pozostałe aspekty życia młodzieży nie będzie ona mieć już znacznego wpływu.

- Należy na koniec podkreślić, że nie ma znaczących różnic między młodzieżą w obu krajach. Polscy uczniowie jedynie wydają się być bardziej zainteresowani pandemią, 
lepiej oceniają zmaganie się z władz państwowych z pandemią i częściej preferują bierne spędzanie czasu. U ukraińskich uczniów obserwuje się zaś wyższy poziom szczęścia, częstsze zaangażowanie w pomoc seniorom, częstsze spędzanie czasu w sposób aktywny i częstszy udział w lekcjach online.

\section{BIBLIOGRAFIA}

Czapiński J. (2012). Ekonomia szczęścia i psychologia bogactwa „Nauka”, 1, 51-88.

Długosz P. (2020). Blaski i cienie zdalnej edukacji wśród wiejskiej młodzieży. W: Pikuła N, Jagielska K. Łuksik J. (red.), Wyzwania dla edukacji w sytuacji pandemii COVID-19, Kraków: SCRIPTUM. Horney K. (1982). Neurotyczna osobowość naszych czasów. Warszawa: PWN.

Huang Y., Zhao N. (2020). Generalized anxiety disorder, depressive symptoms, and sleep quality during COVID-19 outbreak in China: a web-based cross-sectional survey. Psychiatry research, 112954. Kępiński A. (1986). Psychopatologia nerwic. Warszawa: PZWL.
Poczucie zagrożenia u progu epidemii koronawirusa. (2020). Warszawa: CBOS. https://www.cbos.pl/SPISKOM.POL/2020/K_040_20. PDF (pobrano: 02.11.2020).

Schaeffer K., Rainie, L. (2020). Experiences with the COVID-19 outbreak can vary for Americans of different ages, https://www. pewresearch.org/fact-tank/2020/06/16/ experiences-with-thecovid-19-outbreak-can-vary-for-americans-of-different-ages/ (pobrano: 02.11.2020).

Siek S. (1993). Pranie mózgu. Warszawa: ATK.

Twenge J. (2019). I gen. Przeł. O. Dziedzic. Sopot: Smak Słowa.

Twenge J., Joiner T. (2020). Mental distress among US adults during the COVID-19 pandemic. June 12.2020, https://doi.org/10.31234/ osf.io/wc8ud (pobrano: 02.11.2020).

Якживемолодь Україниучас COVID-19. (2020). http://city-institute.org/ content/ uploads/2020/12/iak-zhyve-molod-ukrainy-u-chas-covid-19.pdf?fbclid=IwAR1KWCMw9F MwseSfoAMktKtf6P92IzUl69fpQ1CAabVI2e6HkbGe48H5M6c (pobrano: 12.12.2020). Kluth A. (2020). Tegoroczne protesty to dopiero początek. Świat wkracza w epokę niepokojów społecznych, https://forsal.pl/lifestyle/ psychologia/artykuly/8012875,pandemia-covid-protestyto-dopiero-poczatek-swiat-wkracza-w-epoke-niepokojowspolecznych-opinia. html. 


\section{3мict}

1. Вступ

38 2. Методологія дослідження

39 3. Характеристика досліджуваних груп

42 4. Зацікавленість проблематикою пандемії

44 5. Рівень страху щодо зараження коронавірусом

48 6. Оцінювання дій влади в умовах пандемії

49 7. Психічне самопочуття молоді

52 8. Життя в цифровому світі

59 9. Життя учнів поза мережею

61 10. Допомога особам похилого віку $\rightarrow$

62 11. Молодь в умовах дистанційного навчання

65 12. Висновки

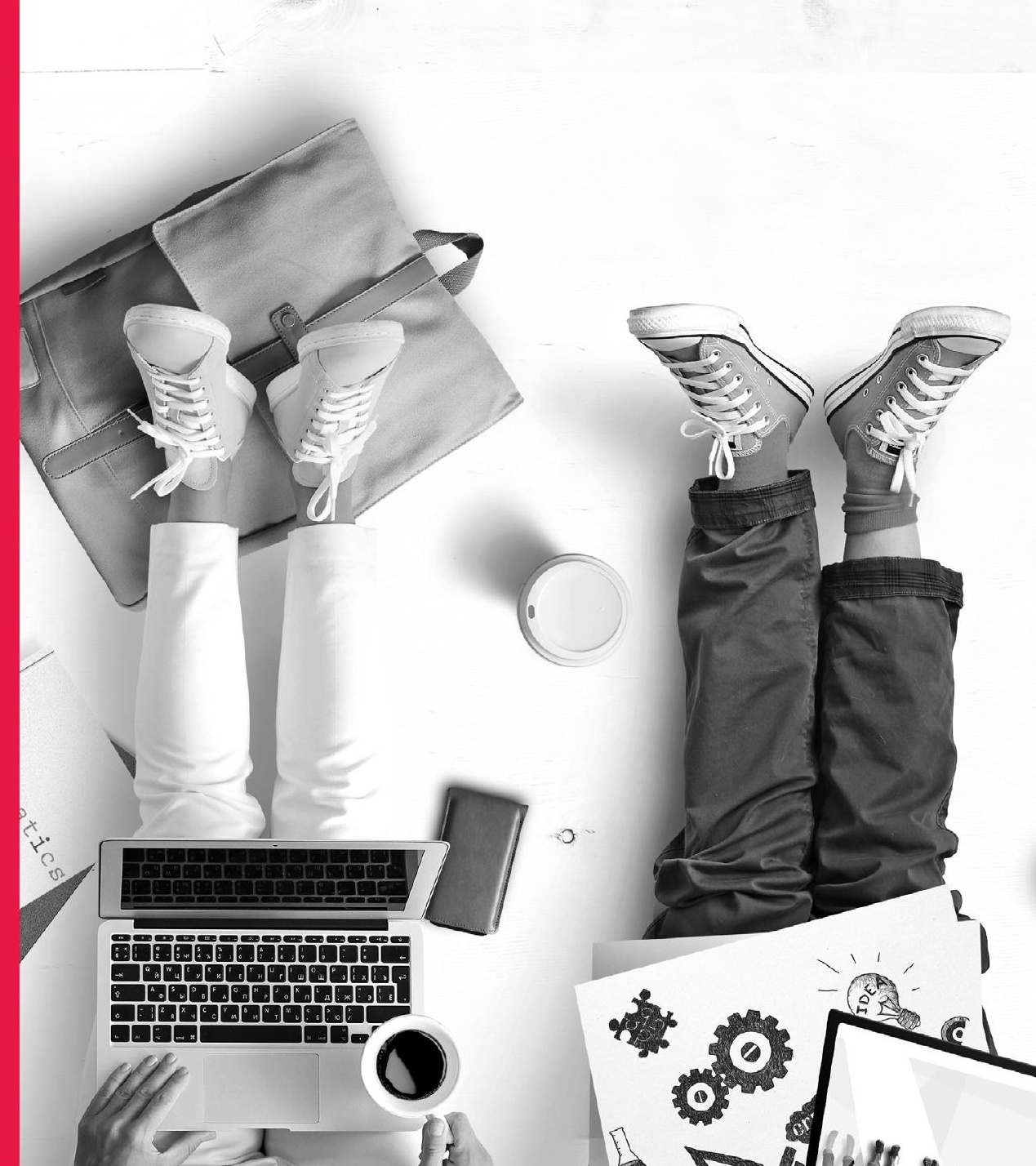




\section{1. Вступ}

- а початку пандемії, коли кількість смертельних випадків почала лякати, в усьому світі основний захист було скеровано на старше покоління. Всі добре пам'ятаємо допомогу волонтерів, що купували продукти для осіб похилого віку, було запроваджено спеціальні години для цих осіб, коли вони можуть робити покупки, мінімізуючи контакт з іншими людьми. Вищезазначені дії мали на меті мінімізувати ризик зараження коронавірусом і - відповідно врятувати їх від смерті, оскільки, в разі зараження, вмирають переважно найстарші (найслабші, з ослабленим імунітетом). Також з досліджень проведених $\mathrm{CBOS}^{1}$,видно було, що особи похилого віку 65+ мають більший страх заразитися (71\%), ніж особи віком від 18 до 34 років (50\%) (Poczucie zagrożenia...2020). Представники наймолодшого покоління вважали, що в разі зараження все одно зможуть одужати, оскільки молодий організм впорається з вірусом так само, як зі звичайним грипом. Звідси, серед молоді не були помітні настрої жаху з боку пандемії Covid-19.

Життя в умовах пандемії COVID-19 супроводжується обмеженнями та проблемами, що $з$ ними стикається кожне суспільство. Обмеження соціальних контактів, труднощі в доступі до розваг та занять спортом можуть спричиняти напругу та розчарування. Це явище особливо помітне серед молоді, на що вказують дослідники з багатьох країн. Результати дослідження Pew Research Center, проведеного у США, показують, що най-

CBOS - Centrum Badania Opinii Społecznej, Polska (Центр дослідження громадської думки, Польща) частіше високого і середнього рівня стресу зазнає молодь у віковій групі 18-29 років (61\%). У старшій віковій групі $30-49$ років показники стресу становили 51\%, у наступній групі - 50-64 років - 47\%, а в найстаршій віковій групі 65+ показники стресу зменшилися до 38\% (Schaeffer, Rainie, 2020). Порівняльні дослідження, проведені до та після спалаxy пандемії COVID-19 на великих вибірках у США та в інших країнах, показують, що показники психічного здоров'я знизилися у всіх вікових групах. Разом з тим, стрес найбільше зріс у наймолодших вікових категоріях (Twenge \& Joiner, 2020; Huang \& Zhao, 2020).

До подібних висновків схиляють також результати досліджень, проведених серед польської молоді, зокрема, серед студентів. Дослідження показують, що пандемія COVID-19 посилила і без того не найкраще психічне самопочуття молоді. 3 80\% до 74\% зменшився відсоток студентів, задоволених своїм життям. Перша частина досліджень була проведена на початку запровадження карантину, друга - наприкінці літнього семестру. Протягом трьох місяців карантину та традиційної перерви у заняттях психічний стан студентської молоді погіршився. Виявлено зростання негативних емоцій та психосоматичних симптомів. Занепокоєння та депресія, як підтверджують багато досліджень, проведених у всьому світі, спричинили домінування афективної сфери. Такий стан молоді також підтверджується результатами досліджень, зокрема, тими, що їх було отримано як відповіді на запитаннящодо їх психічного самопочуття. Більшість студентів 
відчували тривогу (60\%), нудьгу (51\%), а також виснаження (46\%), самотність (34\%), сум (34\%), гнів (25\%), боязнь (19\%), апатію (19\%), жаль (17\%), страх (15\%). Не зважаючи на те, що карантин на початку розглядався як додаткові канікули, небагато молодих людей вказували на позитивні ефекти внаслідок запровадження карантину. Молодь незначноюмірою відчувала зацікавлення (10\%), заспокоєння (5\%), хвилювання (2\%), радість (2\%) (Długosz 2020a). Прикладом негативної реакції учнів стосовно запровадження карантину була така відповідь респондента: „ну, відомо, що бувають гірші та кращі дні. Часом даю собі раду, а часом сиджу... і плачу! Зі знайомими маю лише онлайн-контакти” (Długosz 2020).

Про становище української молоді під час пандемії також можемо дізнатися 3 досліджень, проведених в Україні влітку 2020 p. Майже третина молодих людей відчула погіршення психічного здоров'я під час пандемії (Як живе... 2020).

Пандемія COVID-19 та супутні проблеми суттєво вплинули на психічне здоров’я молоді. Все це нагадує ситуацію, описану Karen Horney (1937) у час після Великої депресії 30-х pp. ХХ ст. Тоді спостерігалися руйнування віри в успіх і поява невротичних реакцій на загрозливе сьогодення та непевне майбутнє. Зазначимо, що велике значення в генезисі неврозів мають культурні та соціальні чинники, а не лише біологічні. У ситуації, що склалася, спричинена пандемією COVID-19, можемо стверджувати, що в умовах сьогодення формується невротична генерація. Antoni Kępiński (1986) стверджував, що слабкість та дратівливість $є$ основними симптомами неврозу. Аналіз результатів досліджень стосовно впливу пандемії на психічне самопочуття молоді вказує на зростання рівня страху, депресії, зниження динаміки життя, втоми та розладів настрою в глобальному масштабі.

Про правдивість цієї тези може також свідчити зростання соціального неспокою під час пандемії. На вулицях Польщі, як також в багатьох інших містах світу можна було побачити молодь, що брала участь в протестах, заворушеннях та вуличних бійках. За оцінками експертів з Carnegie Endowment for International Peace з березня до жовтня 2020 р. відбулося понад 30 протестів в 26 країнах проти обмежень, пов'язаних з епідемією коронавірусу. Згадані фахівці зазначають, що світ входить в еру масових протестів, викликаних пандемією (Kluth 2020).

Метою звіту $є$ представлення впливу карантину на психічне здоров'я та становище молоді в складних умовах пандемії. Дослідження має дати відповідь на питання, як учні середніх шкіл справляються з обмеженнями, запровадженими в обох країнах. Дослідження також має на меті показати, як пандемія як глобальне явище, впливає на молодь у Польщі та Україні. Чи в ситуації глобальної загрози існують відмінності в психічному стані та соціальних реакціях, що виникають внаслідок культурних, соціально-економічних відмінностей чи, скоріше, домінує подібність поглядів, спричинених глобалізацією.

У звіті описано ситуацію на самому початку карантину. Він показує першу фазу стану учнів середніх шкіл в умовах обмежень, що їх було запроваджено внаслідок карантину. У Польщі дослідження було проведено в межах Краківського барометра молоді (Krakowskiego Barometru Młodzieży), реалізованого Центром досліджень молоді Педагогічного університету в Кракові (Centrum Badań Młodzieży Uniwersytetu Pedagogicznego w Krakowie) на замовлення Міської ради Кракова ${ }^{2}$. У Львові дослідження проведено проф. Оленою Шиян, Львівський обласний інститут післядипломної педагогічної освіти.

\footnotetext{
2 Зі сторони Міської ради Кракова допомогу у проведенні дослідження надали п. Justyna Ożóg та п. Paulina Świątek-Wtorkiewicz.
} 


\section{2. Методологія дослідження}

Д;

ослідження в обох містах у Кракові і Львові проводилося за допомогою онлайн-опитування (CAWI). Цей метод допомагає реалізувати дослідження на великих вибірках. Опитування полягає в тому, щоб задати вибраній групі респондентів питання, які зазвичай є закритими і підлягають в подальшому кількісному аналізу даних. В опитуванні була використана онлайн-анкета. Онлайн-опитування $€$ швидким, дешевим методом збирання даних від респондентів, що забезпечує їх анонімність. Його недоліком є відсутність контролю за ходом опитування та особами, що заповнюють анкети. Іншим недоліком $€$ також відсутність репрезентативності. Використати онлайн-опитування можна лише щодо респондентів, що користуються Інтернетом. Однак, незважаючи на певні недоліки методу онлайн-опитування, в ситуації пандемії він $€$ найкращим для проведення досліджень. Варто також підкреслити, що у випадку досліджень молоді маємо $100 \%$ доступ респондентів до смартфонів.

У Кракові дослідження проводились 321 березня по 4 квітня 2020 р., у Львові - з 27 квітня по 17 травня 2020 року. У Кракові дослідження проводилося на вибірці 1768 учнів середніх шкіл, у Львові на вибірці - 2291 учнів середніх шкіл. В обох містах учням середніх шкіл було надіслано посилання на онлайн-анкету. Вибірка досліджен- ня мала цільовий характер, була сформована 3 огляду на доступність респондентів.

В обох містах заняття були призупинені приблизно в однаковий час, тобто 12 березня 2020 р. Дослідження у Кракові проводилося на початку запровадження карантину, у Львові трохи пізніше - під час другого місяця карантину. Варто пам'ятати про цю різницю, оскільки вона може мати вплив на отримані результати. Інакше могли почуватися і поводитися учні на початку карантину, трактуючи цей час як додаткові канікули. I зовсім інші реакції та настрої могли з'явитися в учнів після двох місяців карантину, коли дійшло до деривації потреб.

Тим не менше, доцільно припустити, що карантин однаковою мірою спричинив в учнів появу подібних реакцій та настроїв. На основі отриманих відповідей спробуємо оцінити стан і настрої молоді в обох містах.

Аналіз стосуватиметься питань зацікавленості пандемією, оцінки дій уряду, місцевої влади щодо запобігання пандемії та безпеки населення. Досліджено соціальні практики, пов'язані з охороною здоров'я, психічним станом та реакціями на загрози. Окремі питання стосувалися форм проведення вільного часу, способів використання Інтернету під час карантину, ставлення до дистанційного навчання та впливу карантину на життєві перспективи молоді. 


\section{3. Характеристика досліджуваних груп}

обох країнах жінки частіше, ніж чолові-

ки, брали участь в опитуванні. Загалом, варто зазначити, що в онлайн-опитуваннях (CAWI) жінки переважно частіше беруть участь, як це спостерігається в багатьох дослідженнях з проблематики пандемії.

У Польщі дослідження проводилось у Кракові, в Україні - у Львові. Молодь, що іiі опитували, найчастіше походить 3 міста. Переважна більшість з числа опитаних учнів у Львові походить 3 міста, зокрема, зі Львова (рис. 2). Водночас, у Кракові понад 1/3 респондентів, що брали участь в опитуванні, проживають за містом. Ці відмінності зумовлені різним функціонуванням освітніх систем в обох країнах. В Україні у сільській місцевості функціонують середні школи, що мають характер загальноосвітніх шкіл. У Польщі середні школи в основному розташовані в місті.
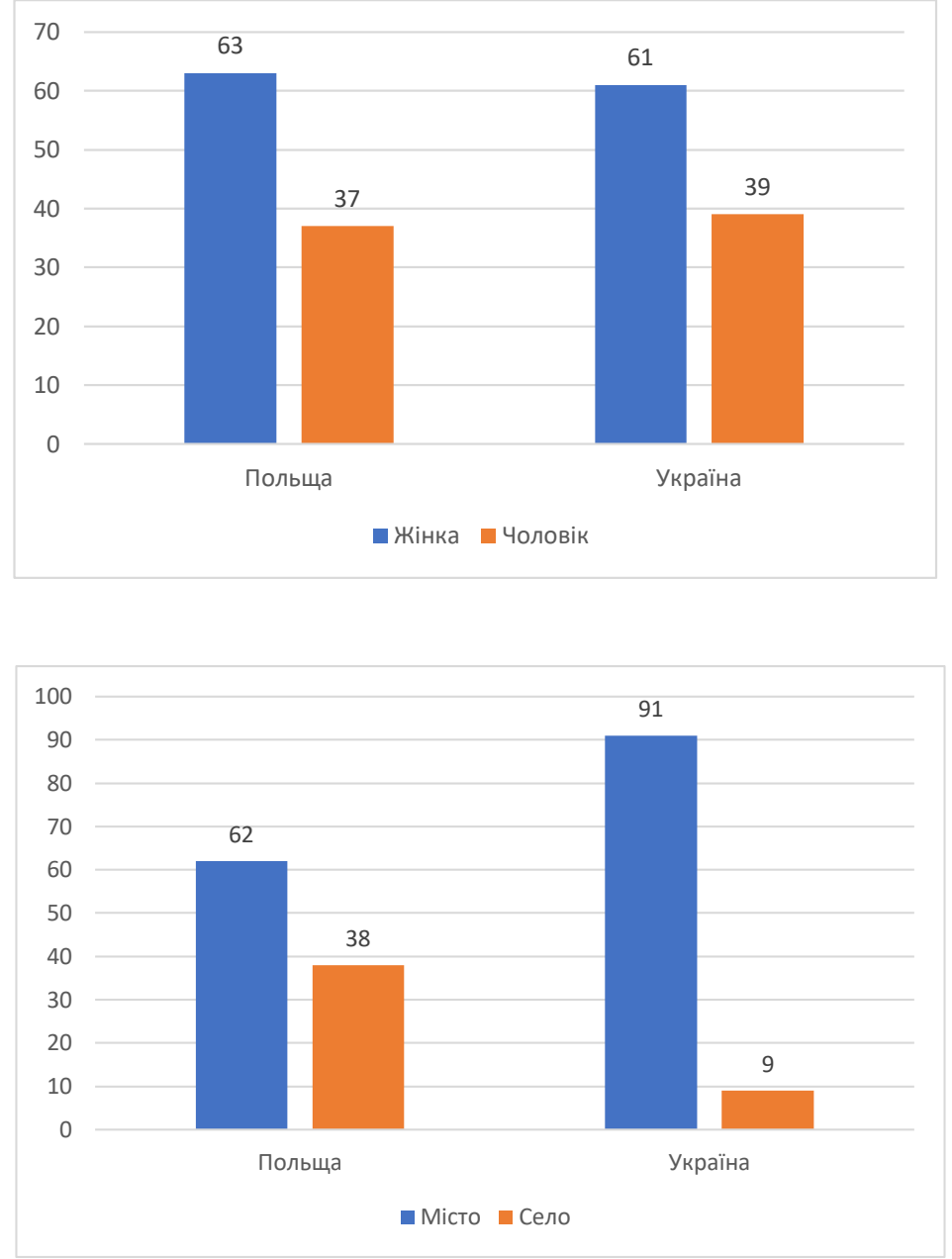

Pис. 1. Стать респондентів (\%)

Рис. 2. Місце проживання (\%) 
У випадку оцінювання матеріального становища учнів застосовували відносний показник, щоб респонденти оцінили рівень свого життя стосовно життя своїх однолітків. Дані показують, що переважна білышість учнів оцінюють свої матеріальні умови життя на середньому рівні. Водночас, як показують результати дослідження, матеріальне становище учнівської молоді подібне в обох країнах (рис. 3).

Ще однією змінною характеристикоює релігійність учнівської молоді (рис. 4). Як бачимо, більше половини опитаних вважають себе віруючими. Разом з тим, українська молодь декларує дещо вищий рівень релігійності.

Більшість опитаних учнів мають мобільний телефон, постійний доступ до Інтернету, комп'ютер та робочий стіл. У своїх помешканнях учні також мають власну окрему кімнату, ноутбуки, плазмові телевізори та стаціонарні комп’ютери. Рідше в сім’ях учнів $\epsilon$ дачні ділянки, твори мистецтва та яхти.

В умовах дистанційного навчання про відсутність доступу до Інтернету в Польщі зазначило 6\% опитаних, а в Україні - 14\%. Варто також підкреслити, що польська учнівська молодь більш забезпечена різними товарами тривалого користування, ніж українська (рис. 5).

Серед краківської молоді більш частіше в домогосподарстві є посудомийна машина та більш, ніж один автомобіль. Також в Польщі учні частіше, ніж в Україні мають
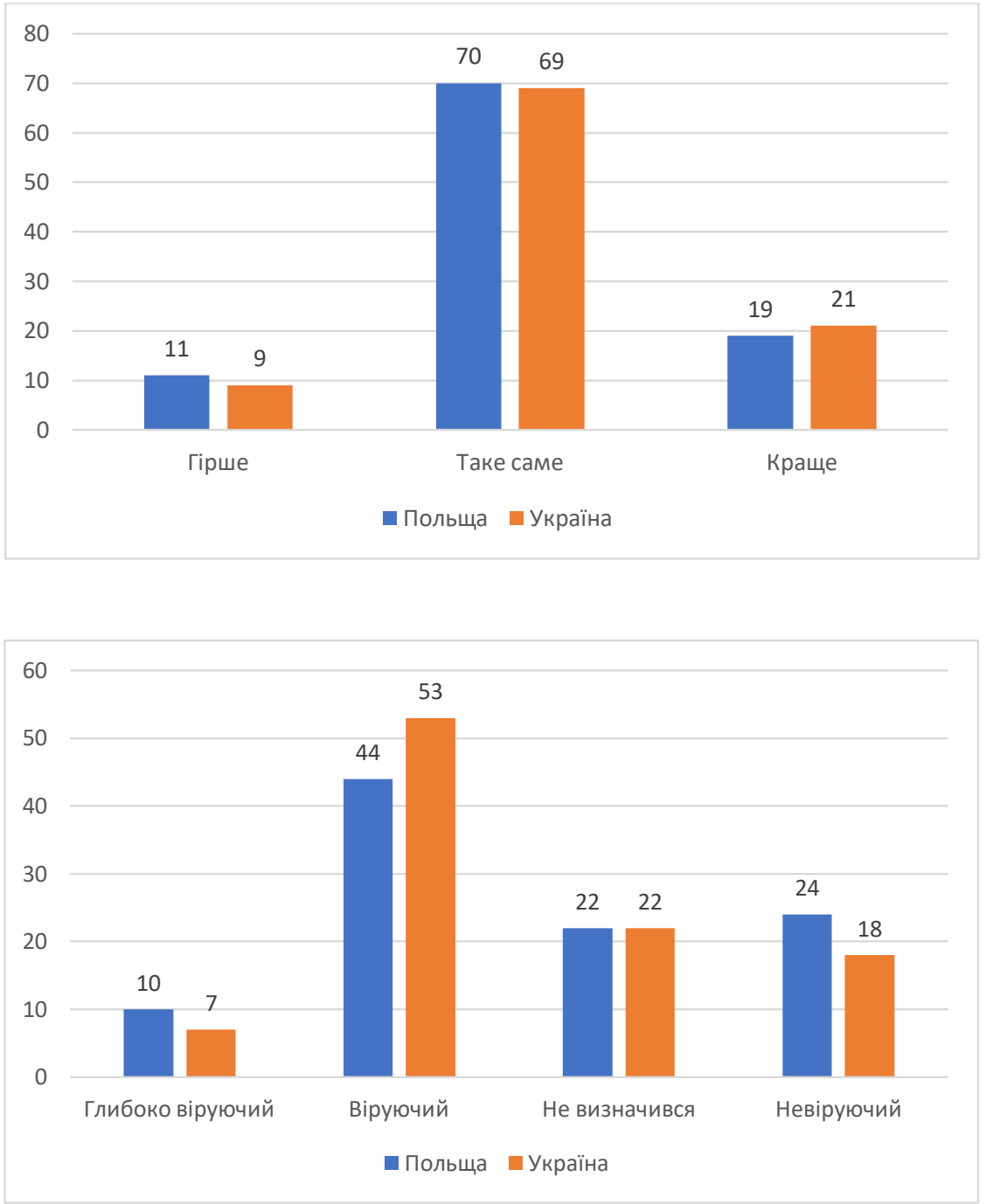

Рис. 3.

Матеріальне становище (рівень Свого життя стосовно життя однолітків) (\%)
Рис. 4.

Релігійність учнівської молоді (\%) 


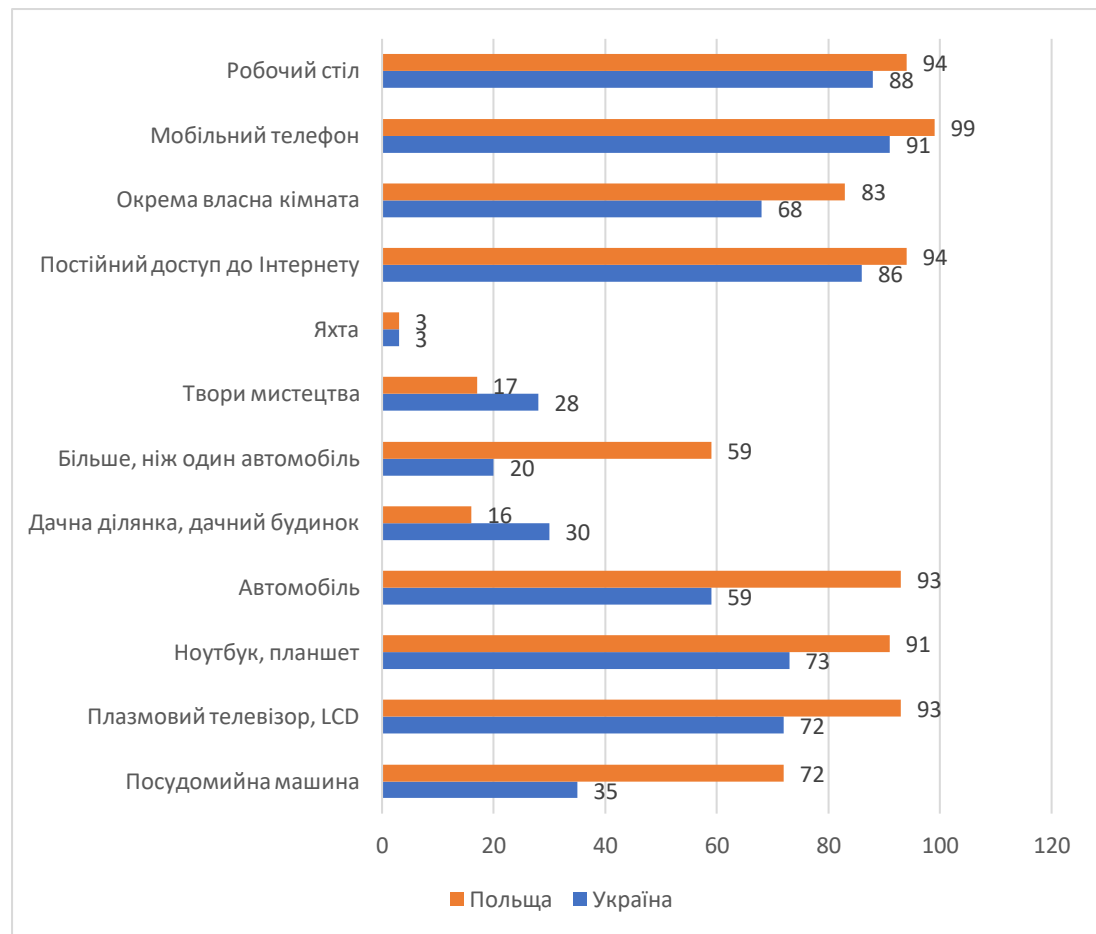

Puc. 5.

Забезпечення домогосподарств (\%) в наявності ноутбуки та планшети. Те саме стосується плазмових телевізорів.

Наступним елементом вивчення груп, на основі яких проводилося дослідження, було питання стосовно освіти батьків (рис. 6). Серед батьків опитаних учнів домінує вища освіта. Причому, в Польщі частіше матері мають кращу освіту, ніж батьки. Натомість, в Україні немає такої відчутної різниці між освітою матерів і батьків.
Підводячи підсумок, за результатами проведеного аналізу, доцільно зазначити, що учні середніх шкіл обох міст Кракова і Львова мають хороші матеріальні умови проживання. Вони мають доступ до телефонів та Інтернету, мають також особисте місце для навчання, походять із освічених родин. Це означає, що дослідженням охоплено представників молоді середнього класу великого міста.

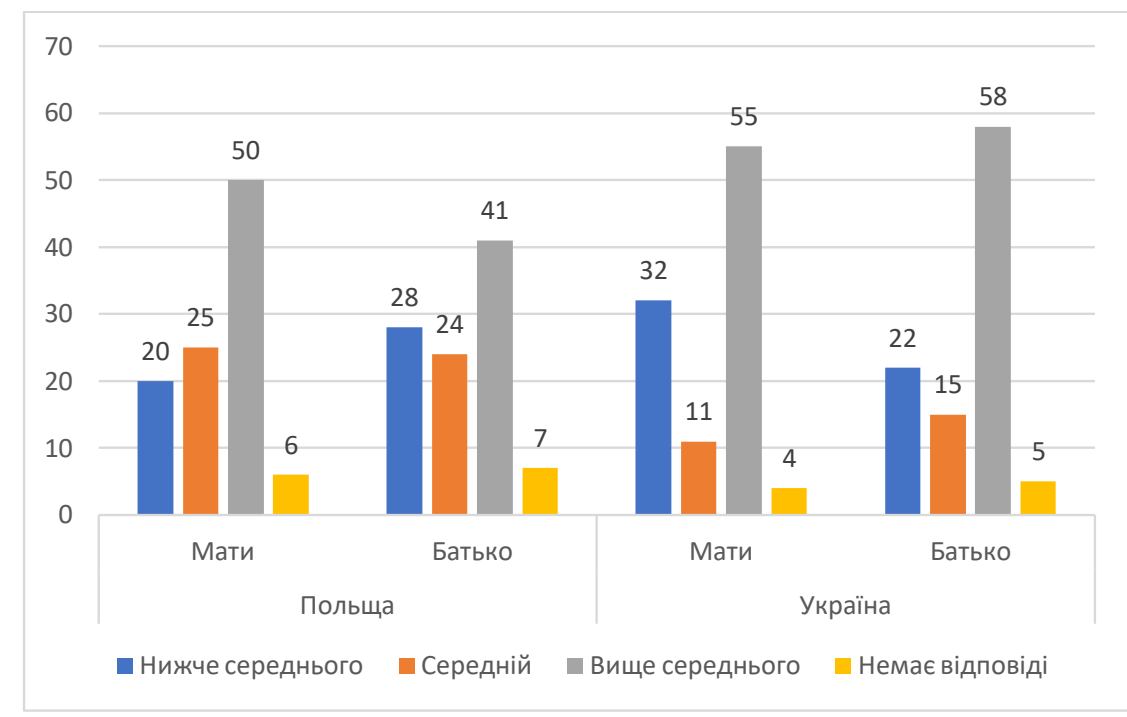

Рис. 6. Рівень освіти батьків (\%) 


\section{4. Зацікавленість проблематикою пандемії}

важаємо за доцільне почати аналіз з роз-

гляду рівня зацікавленості пандемією (рис. 7). Розподіл відповідей показує, що майже всі респонденти цікавляться пандемією, зокрема, що конкретно відбувається в ситуації з коронавірусом, які $є$ проблеми, пов’язані з цим. Небагато респондентів зазначило, що це питання їх не стосується. Разом з тим, порівняння показує, що польська молодь виявляє дещо більший рівень зацікавленості пандемією, ніж українська.

Підтвердженням тези про масове зацікавлення молоді проблематикою пандемії коронавірусу є відповідь на питання, в якому респонденти повинні вказати, чи знають вони поточну кількість інфікованих коро- навірусом. Результати опитування, представлені на рис. 8, показують, що майже всі респонденти знають поточний стан пандемії в країні, зокрема, в Польщі і Україні. Власне, це засвідчує, що респонденти зацікавлені проблематикою пандемії та слідкують за станом розвитку загрози. Окрім цього, в умовах масового висвітлення питання стосовно загрози пандемії і поширення коронавірусу в 3MI та постійного інформування про нові випадки зараження, важко відійти від цієї проблематики. Можливо, відстеження рівня зараження виникає з потреби когнітивного контролю щодо пандемії. Таким чином, учні можуть оцінити масштаби загрози та рівень особистої небезпеки.

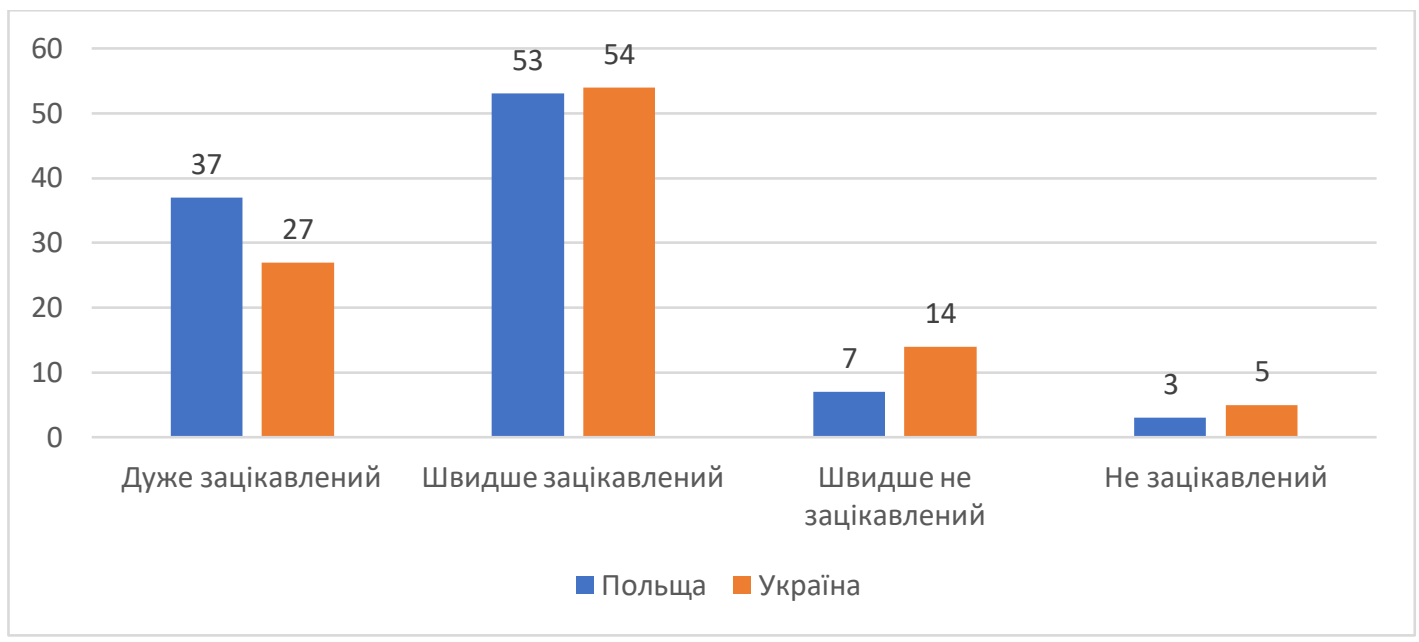

Рис. 7. Рівень зацікавленості проблематикою пандемії (\%) 


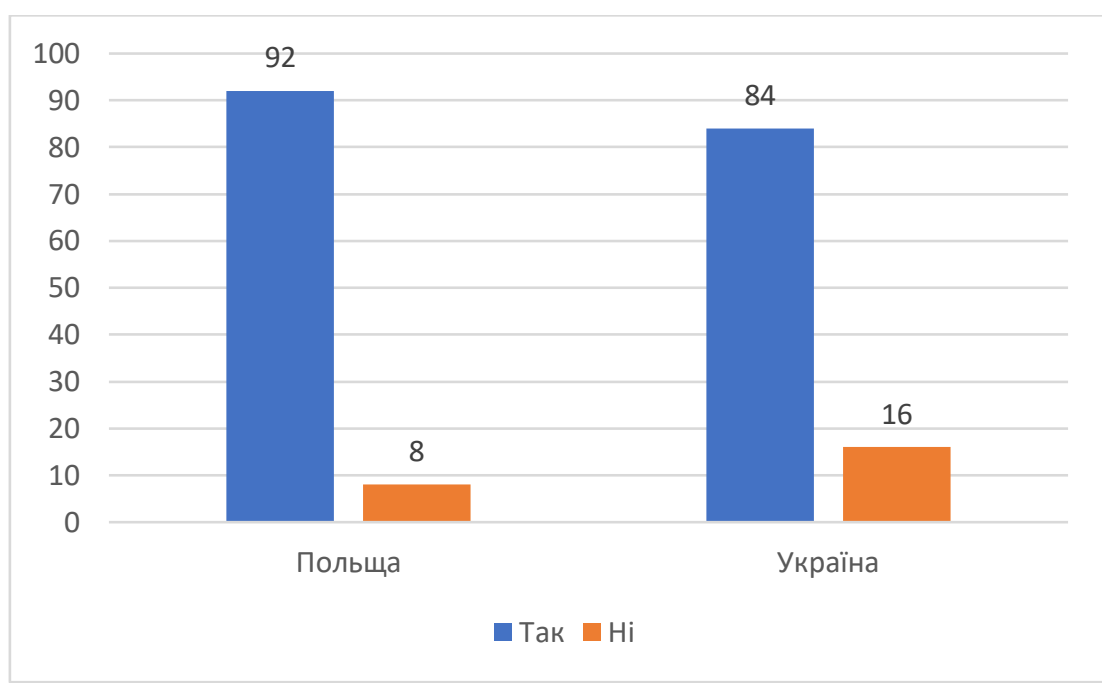

Рис. 8. Рівень поінформованості щодо кількості інфікованих (\%) 


\section{5. Рівень страху щодо зараження коронавірусом}

(1) ереважна більшість респондентів вважає, що коронавірус $\epsilon$ серйозною загрозою для населення обох країн (рис. 9). Порівняння показують, що учні усвідомлюють небезпеку пандемії. Варто також зазначити, що сприйняття загрози коронавірусу однакове серед респондентів Польщі і України.

Наступне питання стосується оцінювання загрози коронавірусу щодо себе (рис. 10). Отримані дані показують, що учнівська молодь в Польщі, меншою мірою в Україні, вважають коронавірус серйозною загрозою для них особисто. У Польщі кожен четвертий учень боїться заразитися особисто, а в Україні - кожен третій респондент. Польські учні дещо менше, ніж українські стурбовані тим, що проблема зараження коронавірусом та наслідки пандемії торкнуться їх особисто.

Аналіз показує, що учнівська молодь переконана, що пандемія COVID-19 небез- печніша для інших людей, ніж для них самих. Це відоме явище в психології, так званий нереалістичний оптимізм (unrealistic optimism). Сутність явища полягає в тому, що більшість людей твердо вірять в те, що інші, а не вони самі, стануть жертвами нещасних подій.

Для отримання відповіді стосовно рівня страху в умовах пандемії коронавірусу учнів також запитали безпосередньо, чи бояться вони бути зараженими. Розподіл відповідей на це питання показує, що в понад $1 / 3$ респондентів можна виявити страх перед загрозою коронавірусу. Приблизно 1/5 респондентів загалом не відчувала жодних проблем. Більшість респондентів мають низький рівень страху щодо зараження. Загалом, рівень особистого страху щодо зараження коронавірусом приблизно схожий в досліджуваних групах обох країнах.

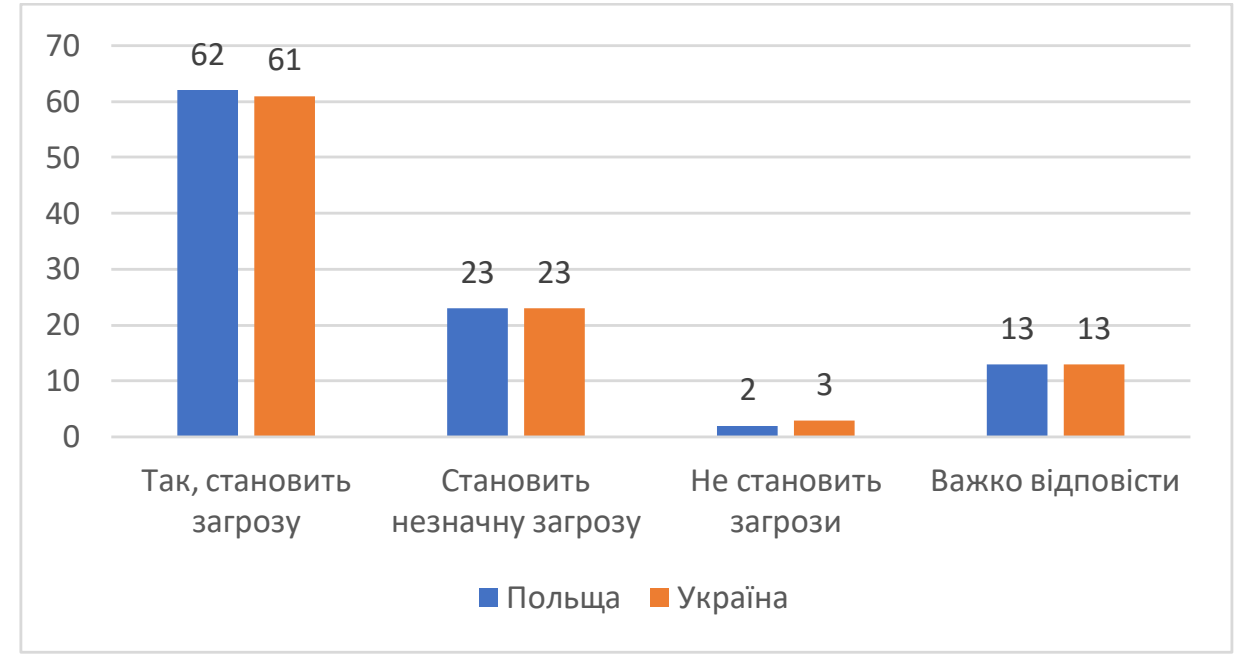

Рис. 9. Чи коронавірус становить загрозу для життя населення країни (\%) 

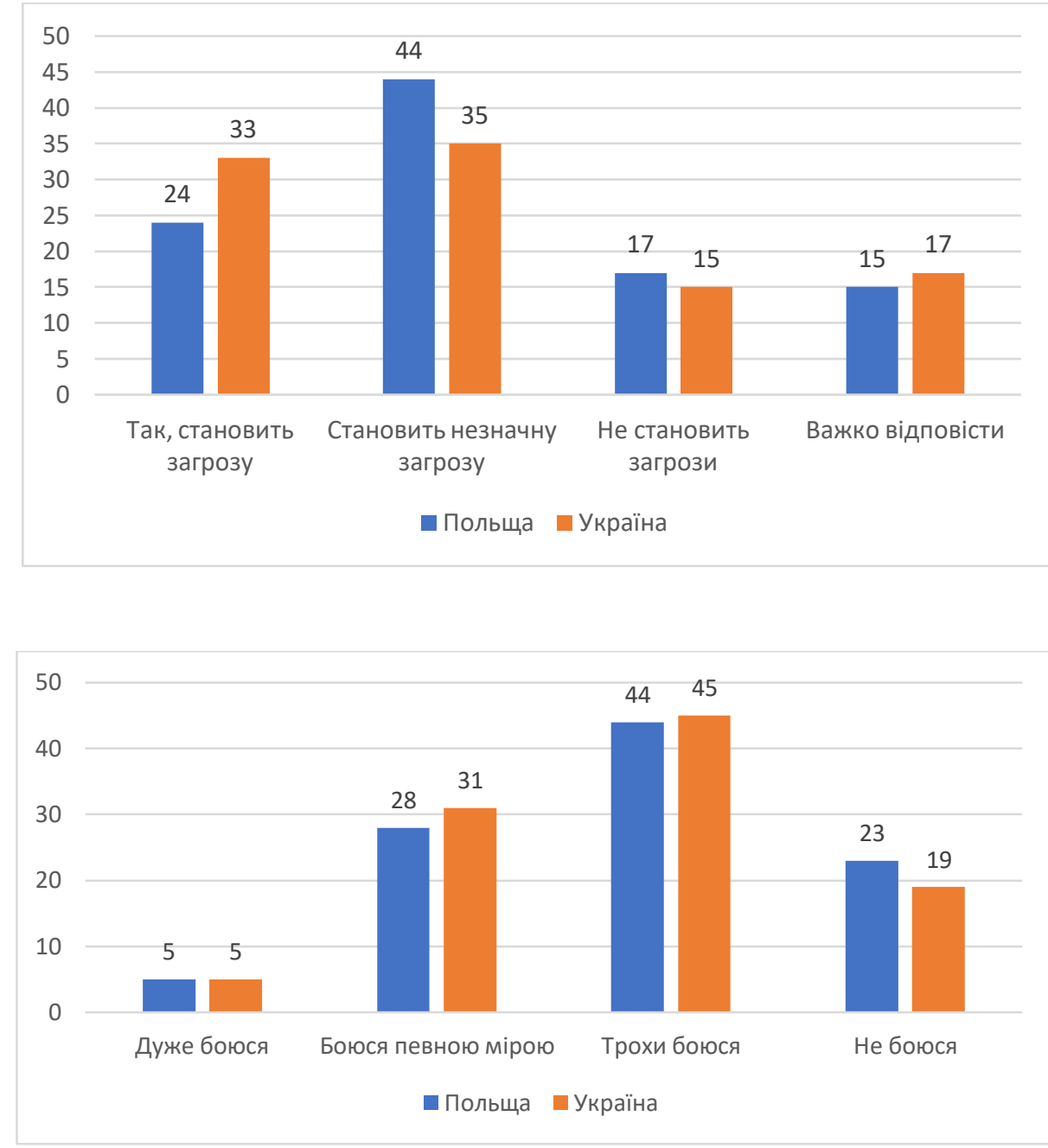

Рис. 10. Чи коронавірус становить загрозу для Тебе? (\%)

Рис. 11. Чи коронавірус становить загрозу для тебе? (\%)

Нижче (рис. 12, 13) представлено розподіл відповідей щодо ймовірності зараження коронавірусом, як прогнозували респонденти. Представлені дані показують, що учні шкіл, швидше за все, не стурбовані потенційним зараженням. За даними дослідження ймовірність зараження за шкалою від 0 до $100 \%$ становила приблизно $30 \%$ в обох країнах.

Відтак, підтверджуються попередні спостереження про те, що рівень страху серед учнів шкіл щодо зараження коронавірусом $\epsilon$ низьким. Варто також додати, що ймовірність зараження, оцінювана краківськими студентами, становила в середньому $40 \%$ (Długosz, 2020a). 3 порівняння цих результатів можемо зробити висновок, що учні шкіл меншою мірою, ніж студенти, знаходяться під впливом стресу щодо зараження коронавірусом.

На рис. 14 показано взаємозв'язок між передбачуваною ймовірністю зараження та рівнем зацікавленості пандемією. Результати вказують, що із збільшенням зацікавленості захворюваннями, викликаними коронавірусом, у респондентів зростає передбачувана ймовірність зараження коронавірусом. Можливо, значна кількість інформації щодо захворюваності та летальних випадків створює враження, що пандемія $\epsilon$ поширеним явищем, якого не вдасться уникнути. Сприйняття великої кількості інформації щодо поширення пандемії може призвести до зниження відчуття безпеки. Психологи 


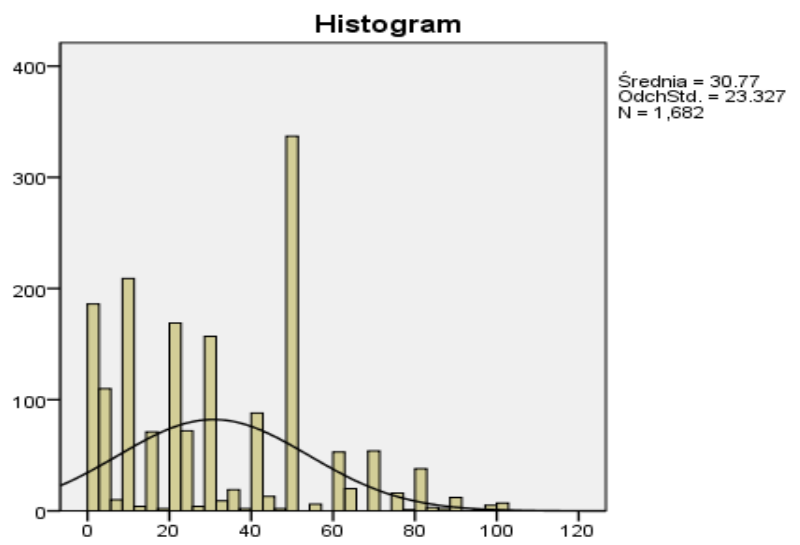

Рис. 12. Ймовірність зараження коронавірусом (Польща)

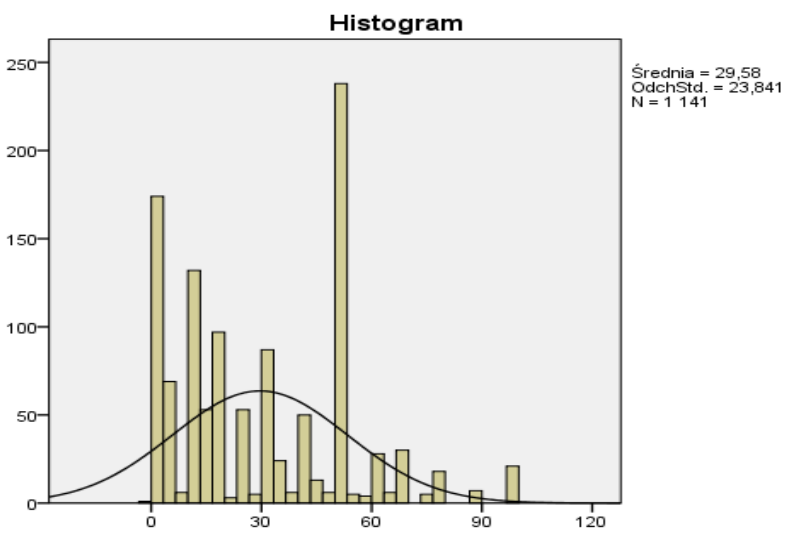

Рис. 13. Ймовірність зараження коронавірусом (Україна)

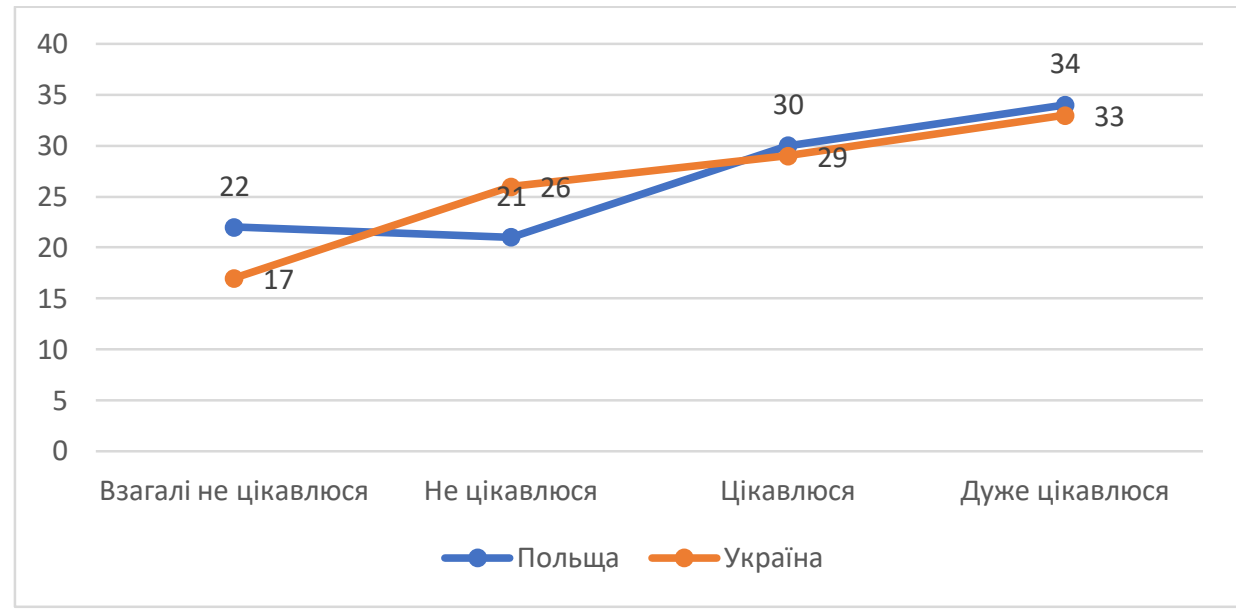

Рис. 14. Вза$\epsilon$ Соз'язок між передбачуваною ймовірністю зараження та рівнем зацікавленості епідемією підкреслюють, що почуття безпеки знижується через постійне бомбардування людини зображеннями насильства, згвалтування, катастроф, війн, хвороб, шляхом постійного нагадування про можливість майбутніх загроз (Siek, 1993). Власне, саме таку ситуацію маємо зараз, а 3MI, намагаючись збільшити свою глядацьку аудиторію, висвітлюють ситуацію з пандемією, демонструючи доволі часто різко негативні зображення.

Для того, щоб перевірити вплив незалежних змінних на рівень страху щодо зараження коронавірусом було створено індекс особистого страху щодо зараження. Індекс створено таким чином, що відповіді з двох питань, що стосувалися страху щодо зараження коронавірусом були об'єднані. Об'єднано відповіді: «так, це становить певну загрозу» та «дуже боюся» були об'єднані.

У результаті підбиття підсумків цих відповідей було отримано три значення індексу, 0 - не було сильного страху, 1 - сильний страх був один раз, 2 - сильний страх був два рази (табл. 1).

Таблиця 1. Значення індексу особистого страху щодо зараження коронавірусом (\%)

\begin{tabular}{|l|c|c|c|}
\hline & $\mathbf{0}$ & $\mathbf{1}$ & $\mathbf{2}$ \\
\hline Польща & 75 & 22 & 3 \\
\hline Україна & 66 & 30 & 3 \\
\hline
\end{tabular}


Результати індексу для обох груп респондентів показують, що рівень страху щодо зараження коронавірусом серед учнівської молоді є низьким, оскільки в польській та українській вибірці лише 3\% мали високий рівень страху. Водночас, середній рівень страху був помітний в кожного п'ятого респондента в Польщі та кожного третього в Україні. Більшість опитаних молодих людей не мали сильних страхів.

Кореляційний аналіз, в якому використано метод r Pearsonsa показав, яка із змінних впливала на інтенсивність страху, що від- бувався ${ }^{3}$. В обох країнах на відчуття страху мали вплив дві змінні: релігійність та зацікавленість пандемією. У випадку Польщі для першої змінної значення $\mathrm{r}=0,100$, для другої змінної - $\mathrm{r}=0,197$. Для України ці значення були вищими. Для релігійності - r=0,147, для зацікавленості пандемією - r=0,219. Аналіз показує, що водночас із зростанням релігійності та більшою зацікавленістю пандемією, зростає рівень особистого страху перед зараженням коронавірусом.

3 Коефіцієнти кореляції є статистично значущими 


\section{6. Оцінювання дій влади в умовах пандемії}

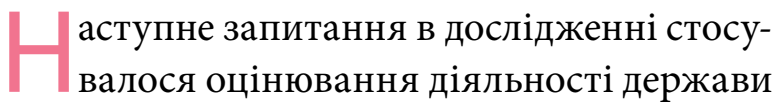
та відповідних служб в умовах загрози пандемії COVID-19. На запитання про дії уряду та місцевої влади щодо безпеки і захисту країни щодо пандемії в обох країнах були отримані різні відповіді. У Польщі переважали позитивні відповіді в оцінюванні дій влади щодо боротьби з загрозою пандеміі, в Україні учнівська молодь скоріш негативно оцінювала дії влади (рис. 15).
Результати дослідження також показали, що в Польщі оцінювання дій влади корелювало з релігійністю $\mathrm{r}=0,121$. Слід розуміти, що релігійні люди, ймовірно, є більш консервативні та оцінювали дії влади краще, ніж нерелігійні люди, які частіше представляють ліберальні погляди.

У випадку з польською молоддю, на оцінку дій влади вплинула політична орієнтація. Натомість, в Україні не було виявлено взаємозв’язку між незалежними змінними щодо оцінки дій влади.

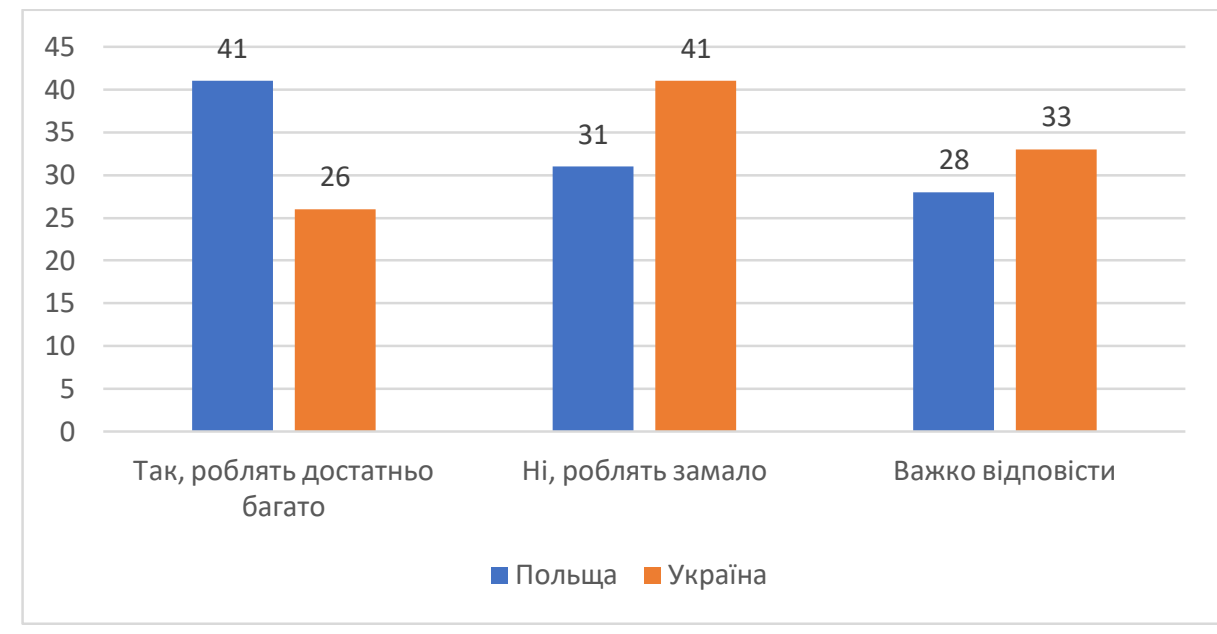

Рис.15.

Оцінювання уряду і відповідних служб в боротьбі 3 пандемією коронавіруcy $(\%)$ 


\section{7. Психічне самопочуття молоді}

I

андемія коронавірусу та їі швидке поширення серед населення i, насамперед, високий ризик смертності, можуть спричиняти соціальні страхи та психічну напругу. Стрес також посилюється зміною звичного способу життя та зростанням невизначеності найближчого майбутнього. Доцільно зауважити, що на сьогодні не знаємо ні економічних, ні соціальних наслідків пандемії. Значною мірою учні шкіл, які тривалий час перебувають в карантинних умовах вдома, можуть відчувати розчарування та напругу, спричинені незадоволенням своїх потреб. У досить складному становищі можуть перебувати учні шкіл, що цього року закінчують школу. Наступні запитання мають на меті показати, як учні шкіл справляються з карантином і чи вплинув він на рівень їх психічного благополуччя.

Дані дослідження показують, що більшість респондентів задоволені своїм життям (рис. 16). Вищий рівень задоволення життям помітний серед української молоді (78\%), дещо нижчий рівень спостерігаємо серед польської (66\%). Кожен п’ятий учень висловив своє незадоволення життям. Отримані результати можуть означати, що психологічне благополуччя є глибшою рисою і не піддається негативному впливу незначних неприємностей та повсякденних труднощів.

Згідно з теорією (Czapiński, 2012), почуття щастя є більш глибшою рисою. Мова іде про аттрактор щастя, що є стійким до зовнішніх проблем. Його роль полягає у мобілізації людини на дії, скеровані на поліпшення актуальної життєвої ситуації. В умовах стресу та загроз люди виявляють волю до боротьби і можуть діяти щодо поліпшення свого функціонування. Благополуччя в умовах пандемї має адаптивну функцію і дозволяє молоді боротися із загрозою. Якби ситуація була зворотною і більшість людей перебувала би в страху та відчаї, було б неможливо впоратися з пандемією.

Також може трапитися так, що в умовах загрози людина втрачає з виду незначні проблеми, хоча у звичних умовах вони могли б погіршити настрій. Людина в умовах загрози зосере-

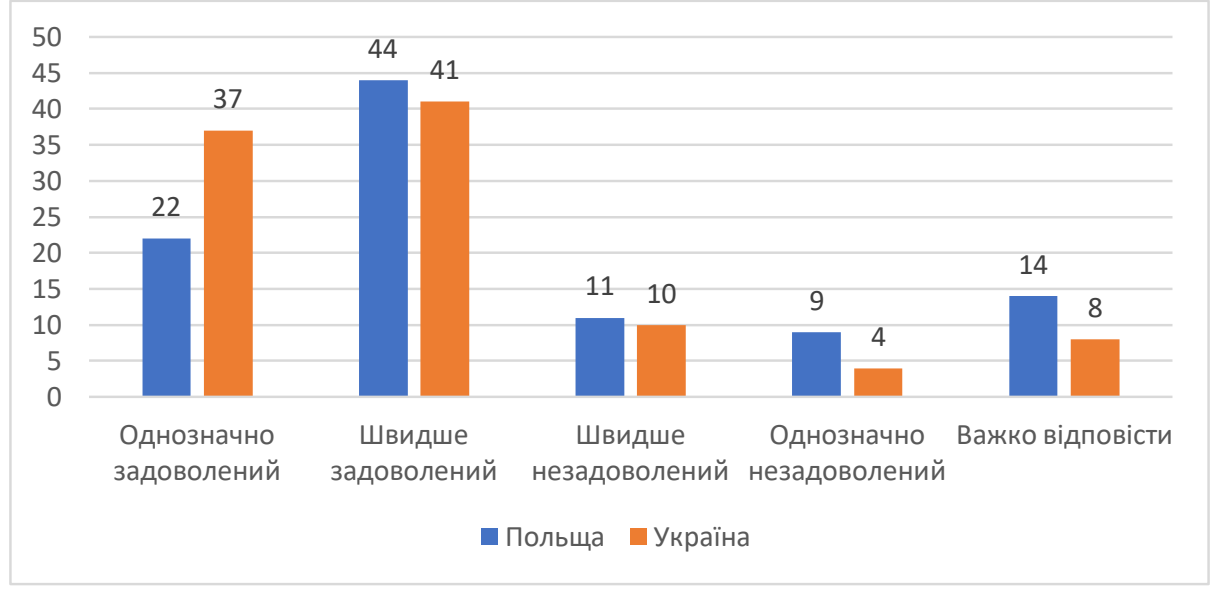

Рис. 16.

Рівень задоволення життям (\%) 
джується на більш важливих речах і цінує те, чого раніше не враховувала, відтак загальний емоційний баланс виявляється позитивним.

Кореляційний аналіз показав, що існує кілька змінних, які корелюють із задоволенням життям. Серед польських респондентів благополуччя співвідноситься зі шкільними досягненнями $(\mathrm{r}=0,114)$, релігійністю $(\mathrm{r}=0,155)$, матеріальним становищем $(\mathrm{r}=0,185)$, інтересом до пандемії $(\mathrm{r}=0,115)$ та оцінкою рівня загрози перед пандемією $(\mathrm{r}=0,102)$. Задоволеність життям зростає із шкільними досягненнями, релігійністю та кращим матеріальним становищем. Краще оцінюють своє щастя учні які більше цікавляться пандемією та усвідомлюють небезпеку пандемії.

Подібні залежності спостерігаються і стосовно українських респондентів. Серед опитаних учнів із збільшенням релігійності зростає рівень задоволення життям $(\mathrm{r}=0,202)$, а також зростає задоволення життям серед респондентів, що краще оцінюють своє матеріальне становище.
Наступні відповіді показують, як учні шкіл реагують на загрозу, що виникає. Проведені спостереження також дозволяють учням оцінити стратегії подолання стресу, спричиненого епідемією.

Найчастіше учні шкіл стараються займатися діяльністю, спрямованою на те, щоб відволіктися від думок, пов'язаних з епідемією коронавірусу. Деякі віддаються заняттям хобі та читають книги. Інші, як показують дії в соціальних мережах (Facebook), публікують свої фотографії з дитинства, щоб разом згадувати і відволікатися від думок про небезпеку пандемії. Другою популярною стратегією $€$ мобілізація та протидія загрозі коронавірусу.

Популярним методом $€$ також раціоналізація, яка полягає в пошуку позитивних сторін в цій ситуації та зосередженні уваги на приємних справах у своєму житті. Як бачимо, учні шкіл використовують стратегію «солодкого лимону», кажучи собі, що ще $\epsilon$ не так погано. Деякі молоді люди шукають соціальної підтримки серед інших людей і просять допомоги в Бога.

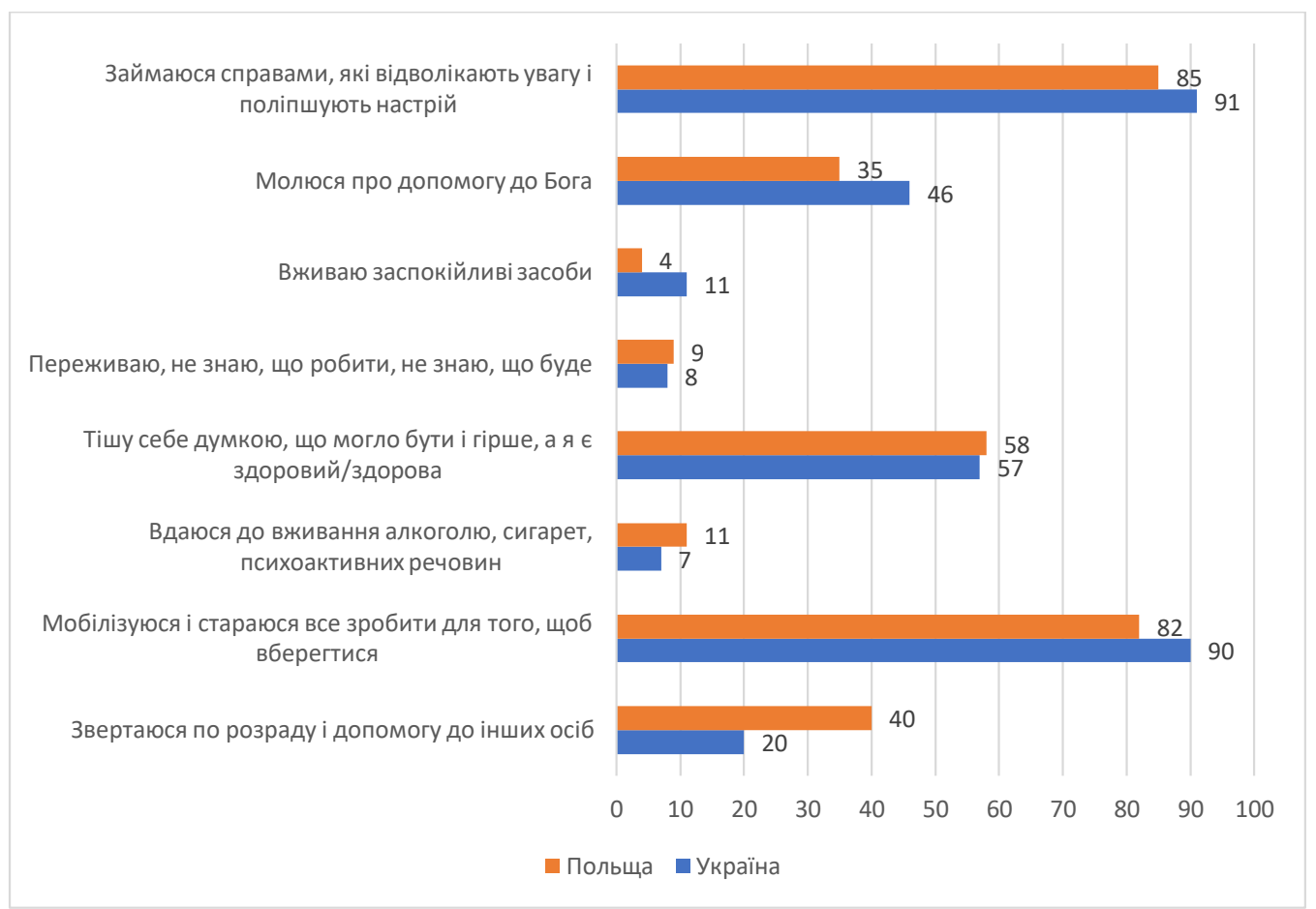

Рис. 17. Як Ви стараєтеся поводитися в ситуації загрози коронавірусу? (\%) 
Табл. 2. Результати кореляційного аналізу стосовно поведінки учнів в ситуації загрози коронавірусу ${ }^{4}$

\begin{tabular}{|c|c|}
\hline Польща & Україна \\
\hline $\begin{array}{l}\text { Звернення за порадою та допомогою частіше характерне для учнів, } \\
\text { більш зацікавлених пандемією }(r=0,119), \text { і тих, хто каже, що це серйозна } \\
\text { проблема для поляків }(r=0,118) .\end{array}$ & $\begin{array}{l}\text { Звернення за допомогою до інших людей характерне для учнів, які } \\
\text { більше бояться заразитися }(r=0,130) \text { і тих, хто релігійний }(r=0,100) \text {. }\end{array}$ \\
\hline $\begin{array}{l}\text { Мобілізація характерна для учнів, які знають про кількість заражених } \\
(\mathrm{r}=0,111) \text {, цікавляться пандемією }(\mathrm{r}=0,221) \text {, вважають, що коронавірус } \\
\epsilon \text { загрозою для поляків }(\mathrm{r}=0,147) \text { та для них особисто }(\mathrm{r}=0,144) \text {. Цю } \\
\text { стратегію частіше вибирають дівчата }(\mathrm{r}=0,165) \text {. }\end{array}$ & $\begin{array}{l}\text { Мобілізація частіша серед учнів, зацікавлених пандемією }(r=0,178) \text {, які } \\
\text { вважають, що коронавірус є серйозною загрозою для українців }(r=0,133) \\
\text { та для них особисто (r=0,114). Цю стратегію частіше використовують } \\
\text { респонденти, які бояться заразитися }(r=0,226) \text {, а також частіше дівчата } \\
(r=0,133) \text {. }\end{array}$ \\
\hline $\begin{array}{l}\text { Вживання алкоголю, психоактивних речовин частіше зустрічається серед } \\
\text { учнів, незадоволених життям }(r=0,115) \text { та менш релігійних }(r=0,117) .\end{array}$ & $\begin{array}{l}\text { Вживання алкоголю, психоактивних речовин частіше зустрічається серед } \\
\text { учнів, які не цікавляться пандемією }(r=0,138) \text { і менш релігійні }(r=0,116) \text {. }\end{array}$ \\
\hline $\begin{array}{l}\text { Думки, що може бути гірше, частіше характерні для дівчат }(r=0,177) \text { та } \\
\text { учнів технікумів }(r=0,129) \text {, в цихучнів такожменш освічені батьки }(r=0,133) \text {. }\end{array}$ & $\begin{array}{l}\text { Думки, що може бути гірше, частіше характерні для учнів, які бояться } \\
\text { заразитися }(r=0,100) \text {. }\end{array}$ \\
\hline $\begin{array}{l}\text { Пасивне споглядання за розвитком поширення коронавірусу частіше } \\
\text { характерне для респондентів, незадоволених життям }(\mathrm{r}=0,148) \text { і серед } \\
\text { дівчат }(\mathrm{r}=0,118) \text {. }\end{array}$ & $\begin{array}{l}\text { Пасивне споглядання за розвитком поширення коронавірусу частіше } \\
\text { характерне для респондентів, незадоволених життям }(r=0,100) \text { і тих, } \\
\text { які бояться заразитися }(r=0,100) \text {. }\end{array}$ \\
\hline \multicolumn{2}{|l|}{$\begin{array}{l}\text { Вживання заспокійливих засобів частіше спостерігається в учнів, } \\
\text { незадоволених життям }(r=0,131) \text {. }\end{array}$} \\
\hline \multirow[t]{2}{*}{$\begin{array}{l}\text { Молитва про допомогу частіше з'являється серед тих, хто задоволений } \\
\text { своїм життям }(r=0,116) \text {, проживає за межами Кракова }(r=0,110) \text {, більш } \\
\text { релігійний }(r=0,616) \text { і хто позитивно оцінює дії влади в боротьбі } 3 \\
\text { коронавірусом }(r=0,116) \text {. }\end{array}$} & $\begin{array}{l}\text { Молитва про допомогу частіше з'являється серед тих, хто задоволений } \\
\text { своїм життям }(\mathrm{r}=0,163) \text {, цікавиться пандемією }(\mathrm{r}=0,150) \text {, вважає, що } \\
\text { коронавірусє особистою загрозою }(\mathrm{r}=0,114), \text { боїться заразитися }(\mathrm{r}=0,270) \text {, } \\
\text { допомагає особам похилого віку }(\mathrm{r}=0,110) \text {, тих, хто декларує вищий } \\
\text { рівень релігійності }(\mathrm{r}=0,567) \text {. }\end{array}$ \\
\hline & $\begin{array}{l}\text { Займаються іншими справами, щоб відволіктися від пандемії в основ- } \\
\text { ному учні, які задоволені життям }(r=0,116) \text {, цікавляться пандемією ( } \mathrm{r} \\
=0,120) \text {, бояться заразитися }(\mathrm{r}=0,115) \text {. }\end{array}$ \\
\hline
\end{tabular}

Результати дослідження показують, що респонденти незначною мірою вчиняють дії, спрямовані на зменшення напруги шляхом споживання алкоголю, психоактивних речовин чи заспокійливих засобів. Мало хто також заявляє, що вони використовують стратегії ескапізму, що полягають у відстороненні від реальності та відданні себе долі, випадковості.

Порівняння обох груп респондентів показує, що стосовно деяких видів діяльності існують відмінності між цими двома групами учнівської молоді. Польська молодь частіше, ніж українська звертається до інших людей за порадою та допомогою (різниця на 20\%). Українська молодь частіше звертається 3 молитвою до Бога, ніж польська (різни-

4 Усі коефіцієнти кореляції r Pearsona $€$ статистично значущими ця на 11\%). Частіше також українські учні намагаються мобілізуватися і бути добре підготовленими до боротьби із загрозою пандемії (різниця на 8\%).

Аналіз даних показує, що учні в ситуації стресу перед пандемією займаються різними видами діяльності. На основі проведеного аналізу доцільно також зазначити, що учні шкіл 3 вищим рівнем психологічного благополуччя та більш релігійні частіше демонструють активні стратегії боротьби із загрозою коронавірусу, а ті, що менш релігійні та незадоволені життям, демонструють пасивні стратегії. Таким чином, можемо зробити висновок, що результати дослідження підтверджують гіпотезу стосовно адаптаційної ролі задоволення життям. Дані показують, що благополуччя може мобілізувати людину до дій і допомогти справитися із складною ситуацією 


\section{8. Життя в цифровому світі}

action

аступним в дослідженні було питання стосовно способу проведення вільного часу. Слід зазначити, що водночас із припиненням занять в школах та обмеженням доступу до розваг та можливості безпосередніх соціальних контактів, в учнів раптово збільшився обсяг вільного часу.

Водночас, з впровадженням карантину, як показують результати дослідження (рис. 18), цифрові тубільці (Digital Natives) перенесли своє соціальне життя у віртуальну реальність, респонденти проводять в середньому від двох, а максимально навіть до восьми годин на день в Інтернеті.

Це означає, що учні, як правило, перебувають у верхніх межах часу, проведеного в Інтернеті. Таким чином, спостереження підтверджують гіпотезу про те, що учні намагаються задовольнити свої потреби в цифровій реальності. Порівняння результатів опитування в обох країнах показує, що час, проведений в мережі, є однаковим. Глобальний підліток має подібні звички незалежно від країни походження. Власне, він є творенням цифрової культури.

Результати кореляційного аналізу показують, що в Польщі більше часу в Інтернеті проводять учні технікумів, ніж ліцеїв $(\mathrm{r}=0,116)$. Молодь менш релігійна проводить у цифровій реальності більше часу $(\mathrm{r}=0,175)$. Більше часу у цифровій реальності проводять також учні, чиї матері менш освічені $(\mathrm{r}=0,100)$. Серед української молоді головним показником часу, проведеного в Інтернеті є релігійність. Чим нижча релігійність, тим більше часу учні проводять в Інтернеті $(r=0,202)$.

Знаємо, що молодь багато часу проводить в Інтернеті. Подальший аналіз покаже, в який спосіб учні витрачають час, і на що його витрачають, перебуваючи в Інтернеті.

На рис. 19 наведено відповіді («часто» та «час від часу»). 3 даних, наведених нижче випливає, що активність молоді в Інтернеті

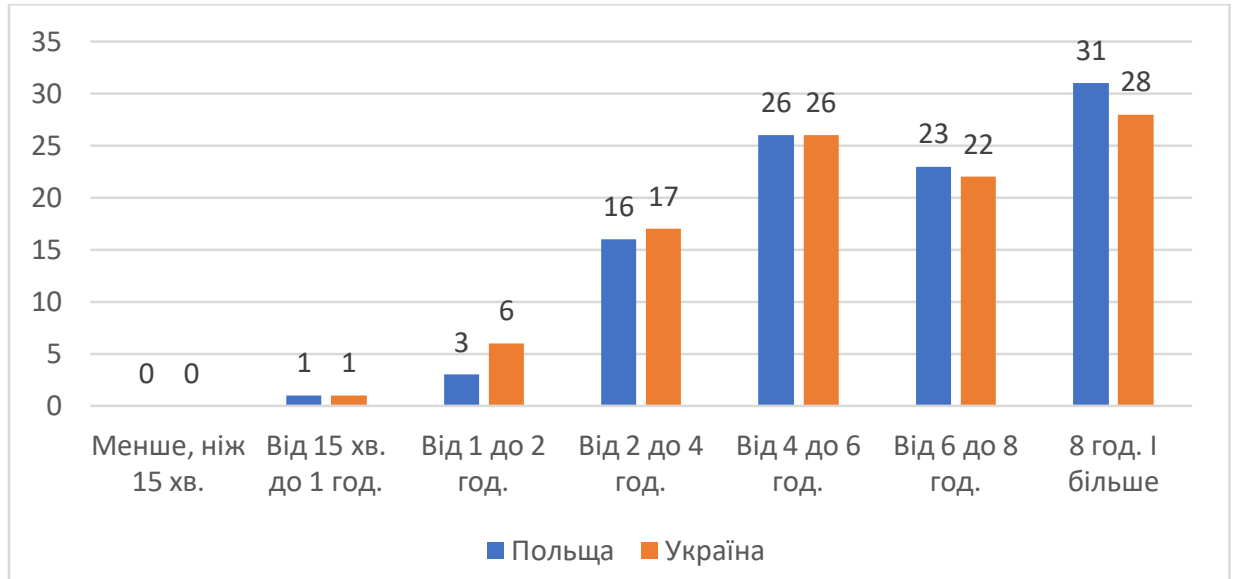

Pис. 18.

Кількість вільного часу, проведеного в Інтернеті під час карантину (\%) 


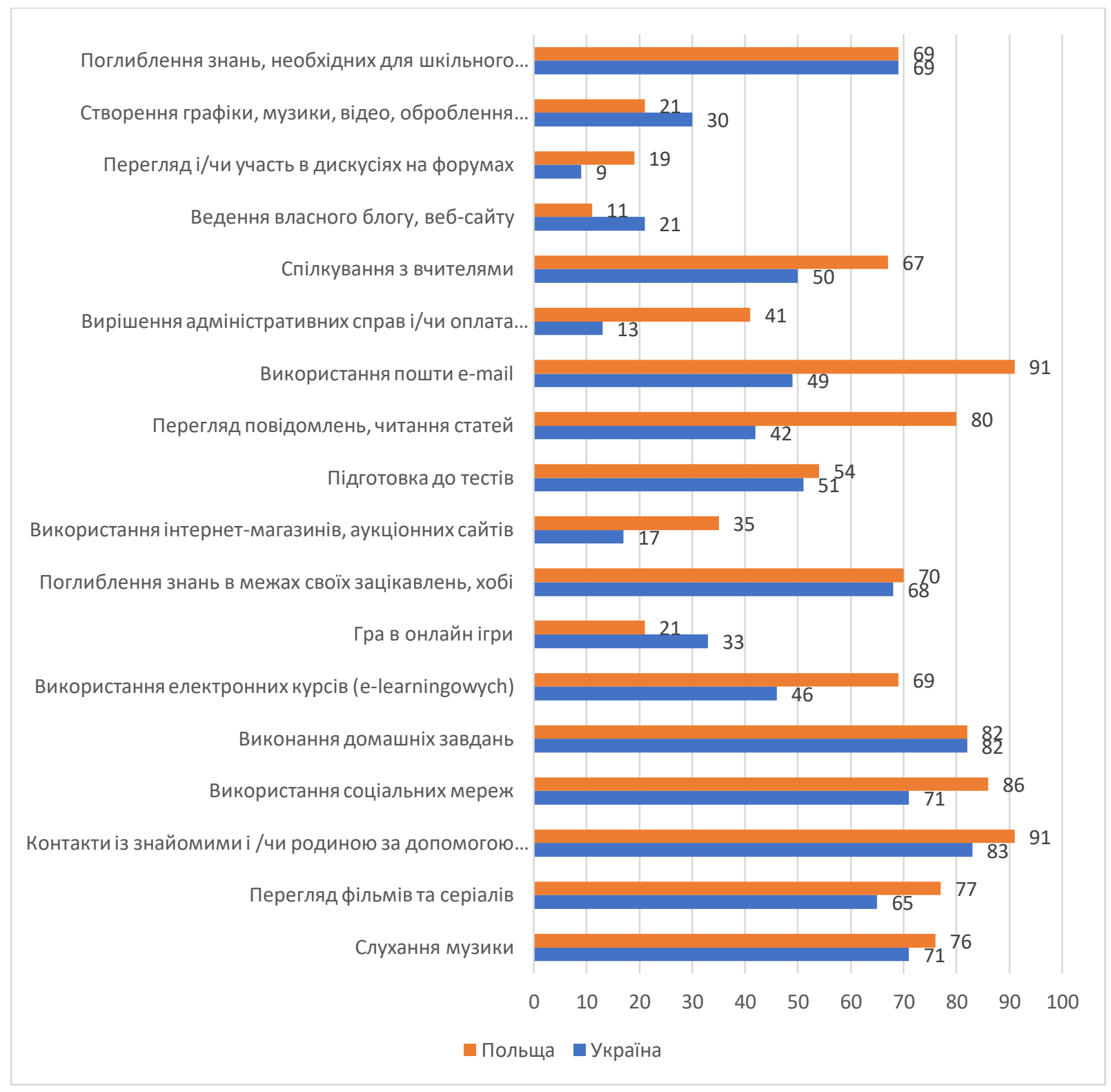

Рис. 19. Типи активності молоді в Інтернеті (\%)

зосереджена на контактах із знайомими через соціальні мережі. Другою важливою сферою активності учнів в Інтернеті $\epsilon$ навчання за допомогою цифрових інструментів. Інтернет також використовують для отримання знань та участі в дистанційному навчанні. Третьою сферою активності в Інтернеті $€$ розваги та відпочинок. Молодь використовує Інтернет для прослуховування музики та перегляду фільмів.
Рідше активність в Інтернеті зводиться до створення графіки, оброблення фотографій. Неохоче респонденти використовують цифрові технології для вирішення адміністративних питань, ведення власного блогу, участі в дискусіях, онлайн-іграх чи здійснення покупок.

Отже, можна зазначити, що учнівська молодь $€$ швидше пасивним, ніж активним користувачем Інтернету, умовах загрози пан- 
демії коронавірусу використовує Інтернет головним чином для соціальних контактів, навчання та розваг.

Порівняння результатів між польськими та українськими учнями показує, що структура використання Інтернету подібна. Однак, в окремих випадках спостерігалися значні відмінності між двома групами респондентів. Польські респонденти частіше використовують Інтернет для відвідування курсів e-learning (різниця на 23\%), здійснення покупок в Інтернет-магазинах (різниця на 18\%), перегляду повідомлень та інформації (різниця на 38\%), використання електронної пошти (різниця на 42\%), залагодження адміністративних справ (різниця на 28\%). Українська молодь частіше декларувала, що створює графіки, музику (різниця на 9\%), веде власний блог (різниця на $10 \%$ ), грає в онлайн-ігри (різниця на 11\%).

Відмінності між двома групами молоді свідчать про те, що польська молодь частіше використовує Інтернет для функціонування в публічній сфері, а українська молодь дещо частіше $\epsilon$ активним учасником цифрової реальності, в якій вона намагається бути не лише пасивним користувачем, але й активним творцем у цифровому світі.

Факторний аналіз дозволяє підготувати типологію активності молоді в Інтернеті. 3 ïi допомогою поєднати види діяльності, які поєднуються між собою, створюючи синдроми активності. Більше того, завдяки факторному аналізу зменшуємо дев’ятнадцять різних видів діяльності до п'яти основних їх вимірів, завдяки чому легше проводити аналіз.

Першим чинником активності молоді в Інтернеті $є$ діяльність, пов'язана зі шкільним навчанням. Це включає виконання домашніх завдань, використання електронних курсів (e-learning), підготовку до виконання тестів, використання пошти e-mail, спілкування з вчителями та поглиблення знань, необхідних для навчання в школі.
Можна зробити висновок, що ця діяльність підпорядкована дистанційному навчанню. Інтернет використовується для проведення шкільного навчання.

Другий чинник включає лише дві практики, що полягають в поглибленні знань в межах своїх зацікавлень, читанні журналів, коміксів. Ці види діяльності можна класифікувати як діяльність,що пов'язана 3 хобі в Інтернеті.

Третій чинник включає такі види діяльності, що стосуються гри в онлайн-ігри, ведення власного блогу, участі в дискусіях на форумах, створення власної графіки і відео. Всі ці згадані види діяльності можна назвати активним використанням Інтернету.

Четвертий чинник зосереджений на таких видах діяльності, як прослуховування музики, перегляд фільмів, спілкування із знайомими через месенджер, використання соціальних мереж. Перелічені вище соціальні практики є загальними для користувачів Інтернету. Значною мірою пересічний учень використовує для таких цілей Інтернет.

П’ятий чинник включає таку діяльність в Інтернеті, що стосується здійснення покупок в Інтернеті, перегляду статей та вирішення адміністративних справ. Молодь також використовує Інтернет для здійснення діяльності, що пов'язана з участю в різних заходах. Ці види діяльності можна класифікувати як участь у публічній сфері.

В результаті факторного аналізу вдалося виокремити п'ять типів поведінки в Інтернеті. Наступним кроком аналізу буде перевірка того, як незалежні змінні впливають на ці виявлені практики. Для цього був проведений кореляційний аналіз, і його результати представлені в таблиці нижче. Можемо докладно побачити, які чинники впливають на той чи інший вид активності в Інтернеті.

Використання Інтернету під час карантину в навчальних цілях видно в учнів, які більше цікавляться пандемією, мають знання про 
Таблиця 3. Результати факторного аналізу щодо способів проведення вільного часу в Інтернеті (Польща)

\begin{tabular}{|c|c|c|c|c|c|}
\hline & \multicolumn{5}{|c|}{ Компоненти } \\
\hline & Навчальний & Хобi & Творчий & Комунікативний & Громадський \\
\hline Слухання музики & & & & 0,505 & \\
\hline Перегляд фільмів та серіалів & & & & 0,520 & \\
\hline $\begin{array}{l}\text { Контакти з знайомими і/чи родиною за } \\
\text { допомогою месенджеру, чатів }\end{array}$ & & & & 0,703 & \\
\hline Використання соціальних мереж & & & & 0,757 & \\
\hline Виконання домашніх завдань & 0,783 & & & & \\
\hline $\begin{array}{l}\text { Використання електронних курсів } \\
\text { (e-learning) }\end{array}$ & 0,483 & & & & \\
\hline Гра в онлайн-ігри & & & 0,278 & & \\
\hline $\begin{array}{l}\text { Поглиблення знань в межах своїх зацікав- } \\
\text { лень, хобі }\end{array}$ & & 0,951 & & & \\
\hline Читання журналів, коміксів & & 0,951 & & & \\
\hline $\begin{array}{l}\text { Використання інтернет-магазинів, аукці- } \\
\text { онних сайтів }\end{array}$ & & & & & 0,688 \\
\hline Підготовка до тестів & 0,762 & & & & \\
\hline Перегляд повідомлень, читання статей & & & & & 0,457 \\
\hline Використання пошти e-mail & 0,578 & & & & \\
\hline $\begin{array}{l}\text { Вирішення справ адміністративних і/чи } \\
\text { оплата рахунків і ін. }\end{array}$ & & & & & 0,704 \\
\hline Спілкування з вчителями & 0,754 & & & & \\
\hline Ведення власного блогу, веб-сайту & & & 0,787 & & \\
\hline $\begin{array}{l}\text { Перегляд і/чи участь в дискусіях на } \\
\text { форумах }\end{array}$ & & & 0,645 & & \\
\hline $\begin{array}{l}\text { Створення графіки, музики, відео, обро- } \\
\text { блення фотографій }\end{array}$ & & & 0,755 & & \\
\hline $\begin{array}{l}\text { Поглиблення знань, необхідних для шкіль- } \\
\text { ного навчання }\end{array}$ & 0,763 & & & & \\
\hline
\end{tabular}

кількість заражених та бояться заразитися. Ці учні більш релігійні, вони живуть за межами Кракова, у них кращі шкільні оцінки, частіше це - дівчата. Аналіз також показує, що навчальний стиль корелює з мобілізацією перед загрозою коронавірусу та з молитвою до Бога про допомогу, а також негативно корелює з використанням психоактивних речовин.

Користування Інтернетом для діяльності, що пов’язана з хобі, часто спостерігається в учнів чоловічої статі, чиї батьки більш освічені. Ці учні також краще забезпечені побутовою технікою, а також вони не нама- гаються використовувати стратегію «солодкого лимону» в умовах пандемії.

Активними користувачами Інтернету, тобто тими, хто намагається щось створити в цифровій реальності, $є$ насамперед хлопці, частіше це також особи, що вживають заспокійливі засоби.

Для комунікативних цілей в умовах карантину частіше використовують Інтернет дівчата, частіше ці учні мають гірші шкільні оцінки, також більше часу протягом дня проводять в Інтернеті. Ці молоді люди частіше схильні до вживання алкоголю, 
Таблиця 4. Кореляти користування Інтернетом (Польща)

\begin{tabular}{|c|c|c|c|c|c|}
\hline & Навчальний & Хобi & Творчий & Комунікативний & Громадський \\
\hline Рівень зацікавленості пандемією & 0,138 & & & & 0,106 \\
\hline Почуття загрози коронавірусу & 0,126 & & & & \\
\hline Релігійність & 0,169 & & & & \\
\hline Місце проживання & 0,108 & & & & \\
\hline Шкільні оцінки & 0,201 & & & 0,102 & \\
\hline Стать & 0,266 & 0,297 & 0,140 & 0,132 & \\
\hline Вік & & & & & 0,173 \\
\hline Тип школи & & 0,136 & & & \\
\hline Освіта матері & & 0,146 & & & \\
\hline Освіта батька & & 0,143 & & & \\
\hline Індекс побутової техніки & & 0,105 & & & \\
\hline Час, проведений в Інтернеті & & & & 0,263 & \\
\hline Інформація щодо кількості заражених & 0,106 & & & & \\
\hline Страх щодо зараження & 0,196 & & & & \\
\hline $\begin{array}{l}\text { Звертаюся по розраду і допомогу до } \\
\text { інших осіб }\end{array}$ & 0,154 & & & & \\
\hline Мобілізуюся & 0,166 & & & & \\
\hline $\begin{array}{l}\text { Вдаюся до вживання алкоголю, сигарет, } \\
\text { психоактивних речовин }\end{array}$ & $-0,159$ & & & 0,109 & 0,131 \\
\hline $\begin{array}{l}\text { Молюся про допомогу } \\
\text { до Бога }\end{array}$ & 0,173 & & & $-0,139$ & \\
\hline Тішу себе думкою, шо могло бути гірше & & $-0,103$ & & 0,101 & \\
\hline Вживаю заспокійливі засоби & & & 0,110 & & 0,101 \\
\hline
\end{tabular}

психоактивних речовин, а також в умовах пандемії втішають себе думкою, що могло бути і гірше. Вони швидше не апелюють до Божого провидіння.

Користування Інтернетом для вирішення різних адміністративних справ, здійснення покупок частіше зустрічається серед учнів старшого віку, які цікавляться пандемією. Вони також частіше мають потяг до вживання алкоголю та психоактивних речовин, а також допомагають собі, приймаючи заспокійливі засоби.

Серед української молоді за допомогою факторного аналізу також виокремлено п’ять типів поведінки в Інтернеті в умовах карантину.

Перший чинник стосується активності, що пов’язана із шкільним навчанням. Сюди входить виконання домашніх завдань, використання електронних курсів, розширення знань відповідно до своїх інтересів, підготовка до тестів, перегляд повідомлень, читання статей, використання електронної пошти, спілкування з вчителями, а також розширення знань, необхідних для шкільного навчання. Можна зробити висновок, що всі ці практики підпорядковані дистанційному навчанню, тобто Інтернет використовується для проведення дистанційного навчання.

Другий чинник можна назвати творчим. На нього впливає ведення власного блогу, участь в дискусіях на форумах, а також створення власної графіки та відео. Всі ці зазначені практики можна назвати активним використанням Інтернету. 
Третій чинник пов'язує такі види діяльності, як прослуховування музики, перегляд фільмів, спілкування із знайомими, друзями через месенджер, використання соціальних мереж. Зазначені вище практики $є$ загальними для користувачів Інтернету. Значною мірою пересічний учень для цих цілей використовує Інтернет.

Четвертий чинник включає такі види поведінки в Інтернеті, як здійснення покупок в Інтернеті, а також вирішення різних адміністративних справ. Ці заходи можуть бути включені до участі у публічній сфері та можливості вирішення справ онлайн.
Останній чинник охоплює участь в онлайн іграх, і можна його зарахувати до практик, пов'язаних $з$ хобі.

Аналогічно, як і в польських даних, на наступному етапі аналізу було зроблено спробу дослідити, як цифрові практики в умовах карантину пов'язані з різними незалежними змінними.

Учні, які віддають перевагу навчальному стилю в цифровій реальності, виявляють зацікавленість пандемією, вважають їі серйозною проблемою, що загрожує життю та здоров’ю українських громадян, а також їм самих. Ці учні частіше беруть участь

Таблиця 5. Результати факторного аналізу щодо способів проведення вільного часу в Інтернеті (Україна)

\begin{tabular}{|c|c|c|c|c|c|}
\hline & \multicolumn{5}{|c|}{ Компоненти } \\
\hline & Навчальний & Творчий & Комунікативний & Публічний & Хобi \\
\hline Слухання музики & & & 0,553 & & \\
\hline Перегляд фільмів та серіалів & & & 0,604 & & \\
\hline $\begin{array}{l}\text { Контакти із знайомими і/чи родиною } \\
\text { через месенджер, чати }\end{array}$ & & & 0,634 & & \\
\hline Використання соціальних мереж & & & 0,681 & & \\
\hline Виконання домашніх завдань & 0,690 & & & & \\
\hline $\begin{array}{l}\text { Використання електронних курсів } \\
\text { (e-learning) }\end{array}$ & 0,609 & & & & \\
\hline Гра в онлайн-ігри & & & & & 0,804 \\
\hline $\begin{array}{l}\text { Поглиблення знань в межах своїх заці- } \\
\text { кавлень, хобі }\end{array}$ & 0,403 & & & & \\
\hline $\begin{array}{l}\text { Використання інтернет-магазинів, аукці- } \\
\text { онних сайтів }\end{array}$ & & & & 0,735 & \\
\hline Підготовка до тестів & 0,723 & & & & \\
\hline Перегляд повідомлень, читання статей & 0,442 & & & & \\
\hline Використання пошти e-mail & 0,542 & & & & \\
\hline $\begin{array}{l}\text { Вирішення адміністративних справ і/чи } \\
\text { оплата рахунків і т.ін. }\end{array}$ & & & & 0,758 & \\
\hline Спілкування з вчителями & 0,677 & & & & \\
\hline Ведення власного блогу, веб-сайту & & 0,742 & & & \\
\hline $\begin{array}{l}\text { Перегляд i/чи участь в дискусіях на } \\
\text { форумах }\end{array}$ & & 0,541 & & & \\
\hline $\begin{array}{l}\text { Створення графіки, музики, відео, обро- } \\
\text { блення фотографій }\end{array}$ & & 0,781 & & & \\
\hline $\begin{array}{l}\text { Поглиблення знань, необхідних для } \\
\text { шкільного навчання }\end{array}$ & 0,750 & & & & \\
\hline
\end{tabular}


у волонтерстві, більш релігійні, мають вищі шкільні оцінки та проводять менше часу в Інтернеті. Серед цих учнів частіше спостерігається потяг до вживання алкоголю та психоактивних речовин і вони частіше відмовляються від інших видів активності для подолання стресу.

Прояви творчої діяльності в Інтернеті корелюються лише зі статтю. Частіше з'являються серед школярок.

Комунікативний стиль користування Інтернетом під час карантину частіше зустрічається у матеріально забезпечених дівчат. Ці учні також проводять більше часу в Інтернеті.
Публічний стиль користування Інтернетом $€$ більш характерним для учнів, які допомагають людям похилого віку з покупками і не схильнідо вживання алкоголю під час карантину.

Останній чинник, що стосується зацікавлень та хобі значною мірою пов'язаний зі статтю. В онлайн-ігри грають в основному хлопці, що не задоволені своїм життям.

Відомо, що досліджувана учнівська молодь належить до покоління iGeneration, тобто покоління Інтернету (Twenge, 2019), тому введення карантину кардинально не змінило їхнього життя, оскільки вони вже до спалаху пандемії були занурені в цифрову реальність.

Таблиця 6. Кореляти користування Інтернетом (Україна)

\begin{tabular}{|c|c|c|c|c|c|}
\hline & Навчальний & Творчий & Комунікативний & Публічний & Xo6i \\
\hline Рівень зацікавленості пандемією & 0,268 & & & & \\
\hline Почуття загрози коронавірусу & 0,144 & & & & \\
\hline Коронавірус є загрозою для українців & 0,101 & & & & \\
\hline Релігійність & 0,153 & & & & \\
\hline \multicolumn{6}{|l|}{ Місце проживання } \\
\hline Шкільні оцінки & 0,143 & & & & \\
\hline Стать & & 0,102 & 0,151 & & 0,519 \\
\hline \multicolumn{6}{|l|}{ Bik } \\
\hline \multicolumn{6}{|l|}{ Тип школи } \\
\hline Задоволення життям & & & & & 0,174 \\
\hline \multicolumn{6}{|l|}{ Освіта матері } \\
\hline \multicolumn{6}{|l|}{ Освіта батька } \\
\hline Індекс побутової техніки & & & 0,137 & & \\
\hline Час, проведений в Інтернеті & $-0,161$ & & 0,243 & & \\
\hline Інформація щодо кількості заражених & 0,144 & & & & \\
\hline Страх щодо зараження & 0,200 & & & & \\
\hline \multicolumn{6}{|l|}{ Звертаюся по розраду і допомогу до інших осіб } \\
\hline Мобілізуюся & $-0,219$ & & & & \\
\hline $\begin{array}{l}\text { Вдаюся до вживання алкоголю, сигарет, пси- } \\
\text { хоактивних речовин }\end{array}$ & 0,181 & & & 0,114 & \\
\hline Молюся про допомогу до Бога & $-0,164$ & & & & \\
\hline \multicolumn{6}{|l|}{ Тішу себе думкою, що могло бути гірше } \\
\hline \multicolumn{6}{|l|}{ Вживаю заспокійливі засоби } \\
\hline Займаюся справами, які відволікають увагу & $-0,137$ & & & & \\
\hline Допомагаю старшим & 0,126 & & & 0,150 & \\
\hline
\end{tabular}




\section{9. Життя учнів поза мережею}

$\cup a c t r$ асто зазначається, що цифровий спосіб життя спричиняє появу в молодих людей труднощів, пов'язаних з великим напливом інформації. Дистанційне навчання посилило явище інформаційного перевантаження. Тому молоді люди також можуть прагнути втекти від цифрової реальності. Як молодь проводить вільний час поза перебуванням в Інтернеті, - показано на рис. 20.

В обох групах учнівська молодь під час вільного часу найчастіше слухає музику. Дещо рідше проводить час за переглядом телевізійних та DVD-фільмів, читанням книг, нічого не роблячи.

Молодь не тільки залишається вдома, але і виходить на вулицю, гуляє, займається спортом. У вільний час молодь також грає в різні ігри на комп'ютері, зустрічається 3 родиною, з своїм хлопцем/дівчиною, друзями. Найрідше молодь читає комікси та пресу.

Слід зазначити, що обстежувані учні дотримуються рекомендацій та обмежують свої контакти з іншими. У незначній мірі використовують перерву від занять в школі для налагодження соціальних контактів.

Варто також зазначити, що стосовно окремих видів дозвілля молоді в обох країнах існують певні відмінності. Польська молодь частіше проводить свій вільний час пасивно, дивлячись телевізор або нічого не роблячи. Натомість українська молодь виявляє більшу активність, зокрема, займається спортом, гуляє, зустрічається з друзями.

Можливо, вказані відмінності виникають внаслідок проведення досліджень у різний період, зокрема, коли в Польщі були введені більші обмеження, ніж в Україні. Однак, ці відмінності можуть бути наслідком культурних відмінностей між Польщею та Україною. Захоплення фізичною активністю та фізичною культурою помітніше в Україні. Молодь виховується через спорт, він повинен формувати характер. Можливо, ситуація $\epsilon$ такою, що учнівська молодь в Україні ще не настільки глибоко занурена в Інтернет-простір і віддає перевагу зустрічам в реальному житті, а не віртуальній реальності.

3 нижче наведених даних (табл. 7) видно, що деякі форми активності відрізняються за статтю. Жінки в обох країнах частіше, ніж чоловіки, дивляться телевізор та фільми, читають книги та слухають музику.

А чоловіки значно частіше, ніж жінки під час карантину грають в комп'ютерні ігри. Цікавим $€$ те, що в обох групах жінки частіше вказували, що у вільний час вони зустрічалися зі своїм хлопцем. 


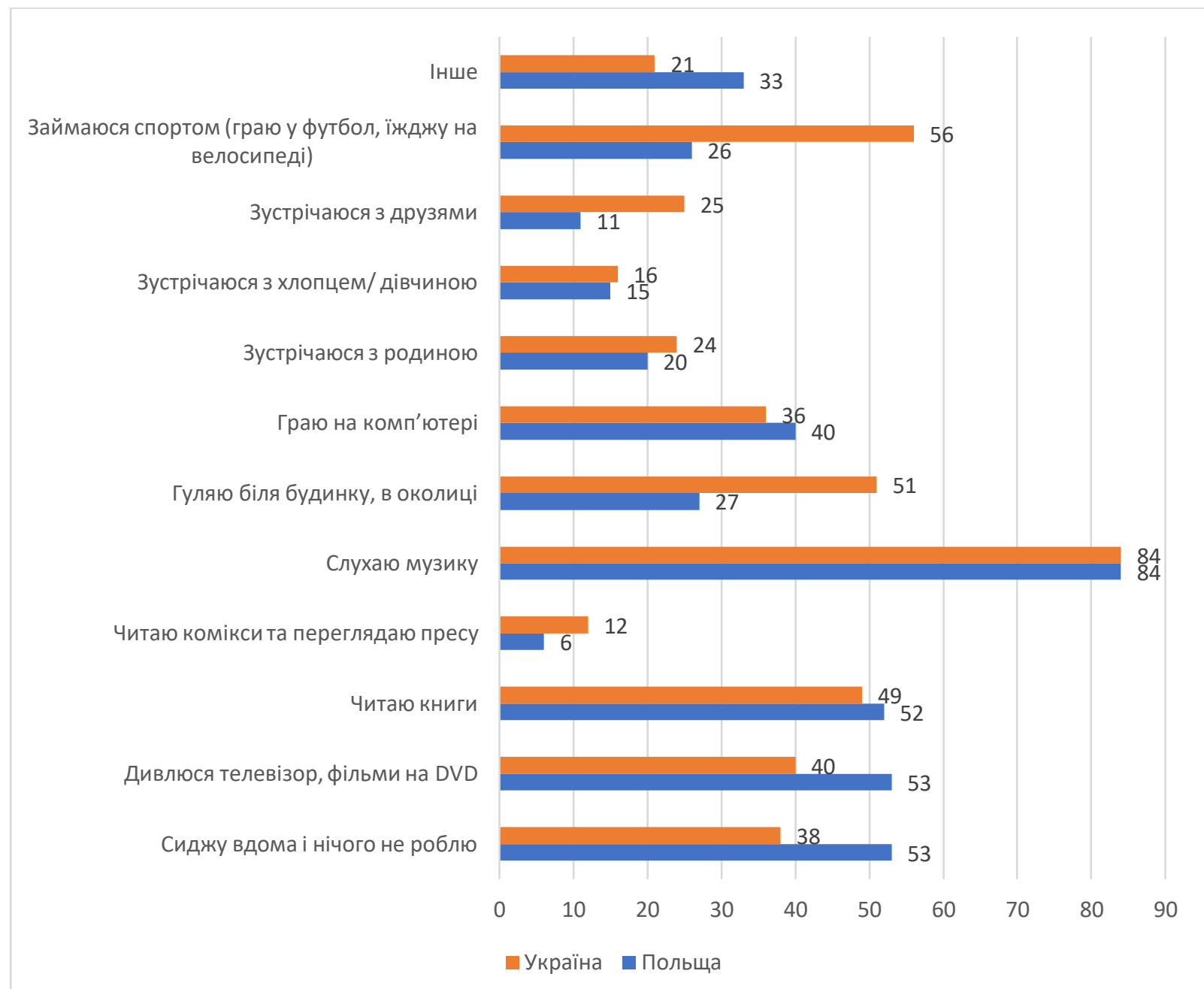

Рис. 20. В який спосіб Ви проводите свій вільний час поза користування Інтернетом? (\%)

Таблиця 7. Організація вільного часу молоді та ії активність відповідно до статі (\%)

\begin{tabular}{|l|c|c|c|c|}
\hline & \multicolumn{2}{|c|}{ Польща } & \multicolumn{2}{c|}{ Україна } \\
\hline & Сінка & Чоловік & Жінка & Чоловік \\
\hline Сиджу вдома і нічого не роблю & 55 & 51 & 39 & 36 \\
\hline Дивлюся телевізор, фільми на DVD & 60 & 42 & 43 & 39 \\
\hline Читаю книги & 56 & 45 & 56 & 40 \\
\hline Читаю комікси та переглядаю пресу & 6 & 6 & 13 & 12 \\
\hline Слухаю музику & 86 & 81 & 88 & 80 \\
\hline Гуляю біля будинку, в околиці & 30 & 22 & 52 & 51 \\
\hline Граю на комп'ютері & 22 & 71 & 17 & 67 \\
\hline Зустрічаюся з родиною & 19 & 23 & 22 & 27 \\
\hline Зустрічаюся з хлопцем/дівчиною & 16 & 13 & 21 & 10 \\
\hline Зустрічаюся з друзями & 11 & 12 & 20 & 26 \\
\hline Займаюся спортом (граю у футбол, їжджу на велосипеді) & 25 & 27 & 58 & 55 \\
\hline Інше & 32 & 35 & 21 & 20 \\
\hline
\end{tabular}




\section{0. Допомога особам похилого віку}

станнім запитанням, що його було розглянуто в цьому підрозділі, $€$ залучення молодих людей до допомоги людям похилого віку. Ця акція пропагується і підтримується через ЗМІ в обох країнах. У зв'язку з цим, також було поставлено питання, чи учні шкіл брали участь в заходах, спрямованих на допомогу та захист людей похилого віку в умовах пандемії коронавірусу.

Отримані результати показують, що невелика частина респондентів була залучена до допомоги людям похилого віку. Допомога полягає у здійсненні покупок та вирішенні різних адміністративних питань чи питань, пов'язаних зі здоров'ям. У Польщі лише кожен п'ятий учень заявив, що брав участь у таких заходах, в Україні кожен третій учень.

У Польщі, як і в Україні більш релігійні учні частіше заявляють про долучення до кампанії допомоги людям похилого віку. Це означає, що дотримання релігійних цінностей підвищує рівень залучення молоді до діяльності для інших людей, зокрема, для людей похилого віку.

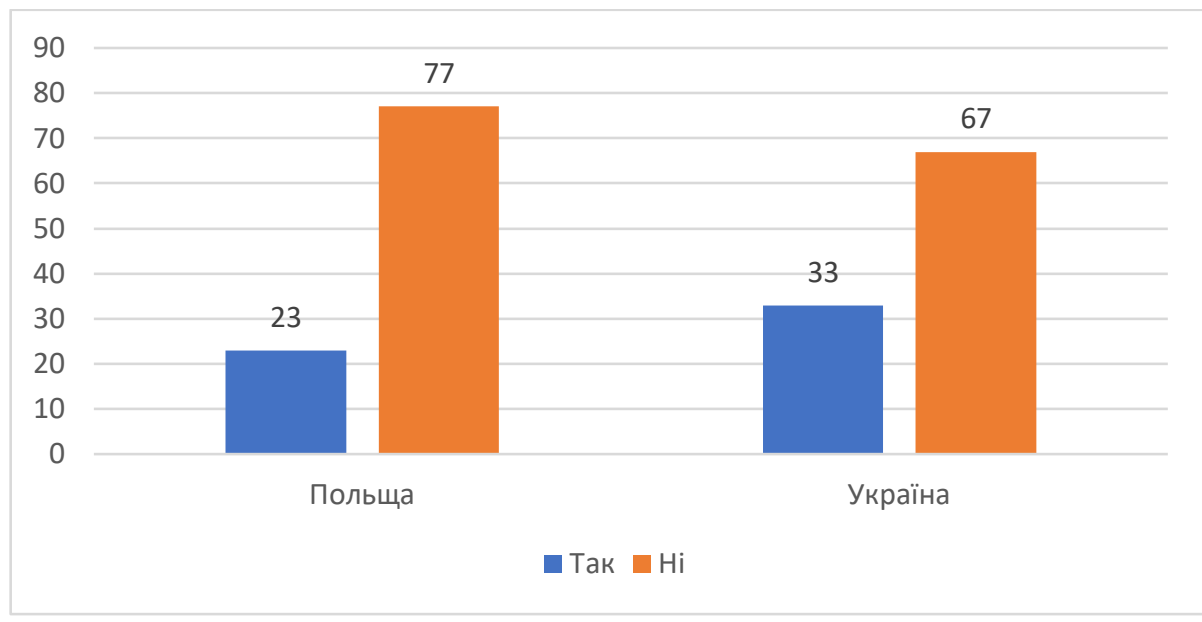

Pис. 21. Чи в умовах карантину Ви допомагаєте людям похилого віку зробити покупки, залагодити різні справи? (\%) 


\section{1. Молодь в умовах дистанційного навчання}

P ризупинення занять в школах змусило вжити заходів, що дозволили б продовжувати навчання у дистанційній формі. 3 кожним днем адміністрація школи, вчителі, батьки, а також насамперед, самі учні постали перед новими викликами. Ця ситуація створила проблеми для кожного, починаючи від технічних проблем, пов’язаних $з$ доступом до Інтернету та наявності відповідного обладнання - через проблеми, пов'язані з цифровими, інформаційними компетенціями - аж до проблем дидактичних, що полягають в пристосуванні процесу передачі знань до інструментів, що використовуються в школах та до навичок учнів. Особливо учні малодших класів мають проблеми з переходом на дистанційне навчання, їм важко самостійно долучитися до онлайн-уроків без допомоги батьків. 3’явилося також питання адаптації до форми цифрового спілкування, що вимагає від учнів самодисципліни, концентрації, старанності та самостійності.

Безперечно, це нове явище, що матиме свої наслідки у соціальному та психологічному вимірі. 3 метою оцінювання онлайн-уроків, було задано питання стосовно того, чи брали учні участь в онлайн-уроках. Дані на рис. 22 показують, що 68\% польських учнів брали участь в онлайн-уроках, в Україні рівень участі в онлайн-уроках був дещо вищим і становив 83\%. Варто додати, що дослідження серед польської молоді було проведено на початку запровадження карантину, що також могло вплинути на отримані відмінності в результатах. В Україні дослідження було проведено дещо пізніше, коли школи вже запровадили дистанційне навчання.

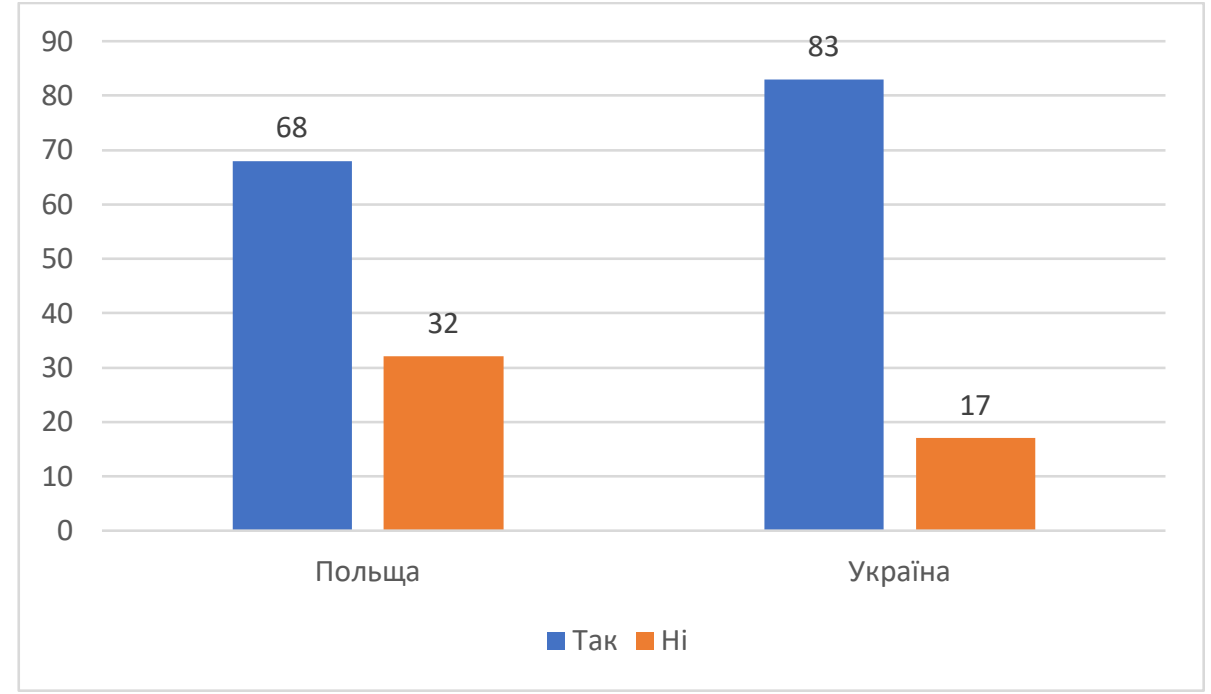

Рис. 22.

Чи брали Ви участь в онлайн-заняттях, які проводили вчителі школи? (\%) 


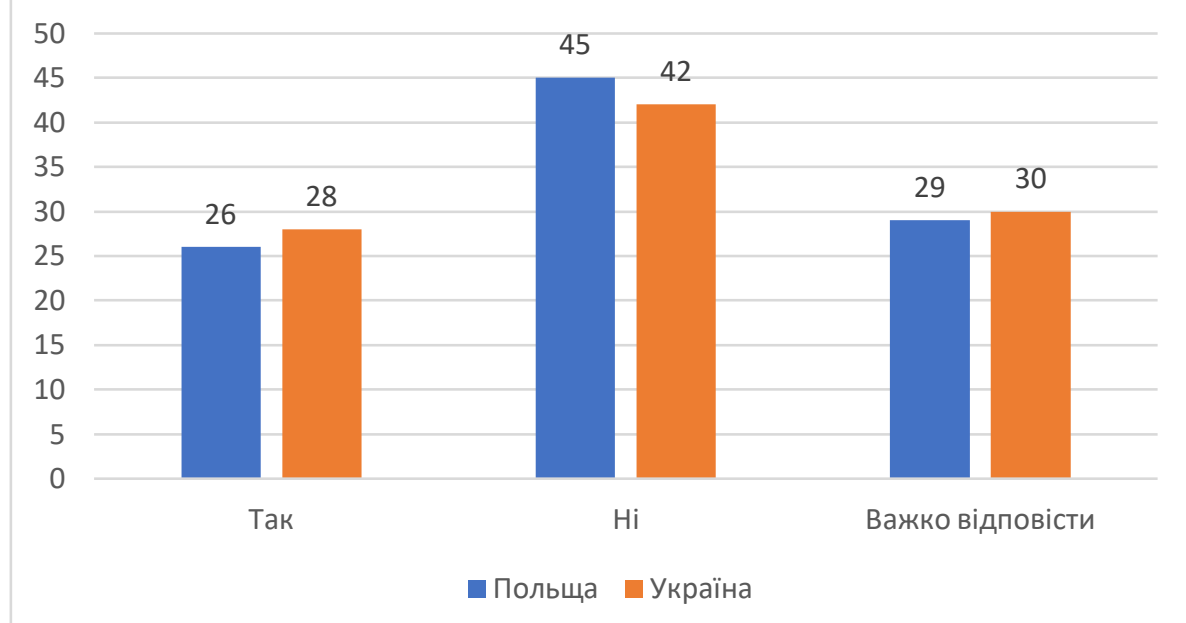

Рис. 23.

Чи вважа-

єте Ви, що

онлайн-за-

няття так

само ефек-

тивні в отри-

манні знань

3 шкільних

предметів,

як і традиційні уроки? (\%)

Також було поставлено питання до учнів стосовно їх думки про вплив дистанційного навчання на рівень їх знань. Розподіл відповідей показує, що самі учні негативно висловлюються щодо ефективності дистанційного навчання. Онлайн-уроки не визнаються учнями. Лише приблизно кожен п’ятий респондент вважає, що дистанційне навчання може замінити традиційне навчання. В обох країнах молоді люди мають подібну позицію.

Аналіз результатів показує, що краще оцінюють онлайн-уроки ті учні, що брали участь в таких заняттях, і гірше ті, що не брали участі в дистанційному навчанні.

Останнє запитання під час опитування стосувалося впливу пандемії коронавірусу на життєві шанси молоді. Ситуація тривалого каран- тину також може мати свої наслідки у багатьох аспектах. Відсутність традиційних занять в школі може призвести в подальшому до зниження рівня знань. Онлайн-заняття не можуть повною мірою замінити традиційні форми навчання.

Карантин позбавив учнів можливості брати участь у додаткових позакласних заходах, спортивних, мистецьких, брати приватні уроки. Важко передбачити, як дистанційне навчання вплине на рівень знань учнів, зокрема, при оцінювання на державній підсумковій атестації. Ще важче визначити, як пандемія та супутні проблеми, наприклад, економічна криза, вплинуть на ринок праці, можливості кар'єрного росту, добробут.

Представлені дані (табл. 9) показують очікуваний вплив призупинення занять

Таблиця 8. Який вплив на Вас може мати призупинення занять в школі? (\%)

\begin{tabular}{|l|c|c|c|c|c|c|c|}
\hline & \multicolumn{9}{|c|}{ Польща } & \multicolumn{3}{c|}{ Україна } \\
\hline Рівень шкільних знань & 19 & 40 & 41 & 19 & 43 & 38 \\
\hline $\begin{array}{l}\text { Результати державної підсумкової } \\
\text { атестації (еgzаmіn maturalny) }\end{array}$ & 14 & 48 & 38 & 24 & 45 & 31 \\
\hline Шанси вступу в престижний ВН3 & 13 & 55 & 32 & 19 & 46 & 35 \\
\hline Життєва кар'єра & 16 & 58 & 26 & 26 & 51 & 23 \\
\hline Професійний (шкільний) успіх & 16 & 59 & 25 & 23 & 49 & 28 \\
\hline Задоволення життям & 31 & 35 & 34 & 48 & 31 & 21 \\
\hline
\end{tabular}


в школах на різні сфери життя учнів. Аналіз показує, що молодь в обох країнах найчастіше переконана, що призупинення занять в школах не вплине на їхнє життя.

Якщо взяти до уваги негативні наслідки пандемії, то в Польщі учні частіше наголошували на тому, що карантин може вплинути на зниження рівня шкільних знань та погіршити результати на державній підсумковій атестації (egzamin maturalny).

А в Україні молодь частіше боїться негативного впливу дистанційного навчання на рівень шкільних знань та шанси вступу у престижний ВНЗ, здобути якісну освіту.
У меншій мірі учні вважають, що в результаті пандемії вони матимуть проблеми 3 досягненням шкільного успіху та подальшою життєвою кар'єрою.

Варто зазначити, що, коли учні говорять про позитивні сторони цієї ситуації, вони вказують на можливість підвищення задоволення життям. Особливо це помітно серед української молоді. Можливо, частина молоді сприймає призупинення занять в школах як звільнення від шкільних обов’язків та пов’язаних з цим незручностей, що, своєю чергою, мало 6 покращило психологічне благополуччя молоді. 


\section{2. Висновки}

po роведені дослідження та представлені результати дають змогу зрозуміти ситуацію серед учнів шкіл на початку карантину в Польщі та Україні. Завдяки опитуванню можемо зрозуміти, в якому стані перебувала молодь під час карантину і в який спосіб справлялася з цією незвичною та складною ситуацією, зокрема, вимушена ізоляція, закриття шкіл та призупинення економіки.

- Проведене дослідження показує, що молодь цікавиться пандемією та стежить за повідомленнями про неї. Володіє також інформацією стосовно кількості заражених в поточний момент. Причому, польська молодь більше цікавиться пандемією, ніж українська.

- Більшість опитаних вважають, що коронавірус представляє серйозну загрозу для здоров'я та життя громадян. У меншій мірі учні вважають, що коронавірус $є$ загрозою для них особисто. Водночас, польські учні менше бояться заразитися, ніж українські.

- В обох країнах ймовірність зараження оцінюється на 30\%. Тож особистий страх перед коронавірусом не є високий.

- Оцінка дій влади, відповідальної за боротьбу з коронавірусом, має певні відмінності в оцінюванні в обох країнах. Позитивне оцінювання влади та відповідних служб, відповідальних за безпеку і захист населення, переважає серед польських учнів і негативне - серед українських.

- Більшість молоді в обох країнах задоволені своїм життям. Причому, вищий рівень психологічного благополуччя демонструє українська молодь.

- Найчастіше молоді люди справляються 3 пандемією таким чином, що намагаються відволіктися від загрози, також мобілізуються та боряться з загрозою, дотримуючись засад безпеки, i, дещо рідше, втішають себе, що не $є$ так погано, оскільки ситуація може бути гіршою.

- Більшість часу в умовах карантину молодь проводить в Інтернеті. У цифровій реальності учні виконують діяльність, пов'язану з дистанційним навчанням та шкільними обов'язками. Використовують Інтернет також для спілкування та розваг.

- Учні проводять вільний час також поза Інтернетом. Найчастіше слухають музику, займаються спортом або залишаються вдома. Причому, українські учні частіше займаються спортом і гуляють. Польські учні частіше вважають за краще проводити вільний час пасивно.

- Відносно невелика частина опитаної молоді залучена до допомоги людям похилого віку. Таку активність можна спостерігати частіше серед української молоді, ніж польської.

- Більшість молоді брала участь в онлайнуроках, причому в Україні участь молоді в онлайн-уроках була вищою, ніж в Польщі.

- Оцінка онлайн-занять загалом виглядає негативною. В обох країнах більшість респондентів вважають, що такі заняття не можуть замінити традиційні уроки. Учні вважають, що відсутність тради- 
ційних занять може вплинути на рівень шкільних знань. Однак, на інші аспекти функціонування молоді це не матиме значного впливу.

- Останній висновок $є$ таким, що немає великої різниці між молоддю в обох країнах. Однак, слід зазначити, що польські учні більш зацікавленіпандемією, краще оцінюють дії влади в боротьбі 3 пандемією, надають перевагу пасивному проведенню вільного часу. Натомість, в українських учнів спостерігається вищий рівень щастя, вони частіше допомагають особам похилого віку, частіше проводять вільний час активно і беруть участь в онлайн-лекціях. 